\title{
China's Energy Security: Going Beyond the Traditional Approach
}

\author{
By \\ Yang GAO
}

\begin{abstract}
A Thesis
submitted to the Victoria University of Wellington in fulfillment of the requirements for the Degree of Master of Arts In International Relations
\end{abstract}

School of History, Philosophy, Political Science \& International Relations Victoria University of Wellington 2010 


\section{Abstract}

China's rapidly growing economy has seen a sharp rise in energy consumption and correspondingly a new focus on energy security. Over the last decade, China has adopted an energy security approach emphasizing its external energy supply, especially oil supply, which is quite similar to the approach established in industrialized Western countries (IWCs) since the 1970s' energy crises. However, China's energy situation is profoundly different from the West with over 90 percent of its energy being produced domestically and nearly 70 percent being coal-based. To explain why the approach in China is similar to that of major IWCs, I demonstrate that while the IWCs constructed their energy security concept and subsequent policy responses on their energy situation, China's approach has largely been influenced by a domestic ideational factor and Western energy security concept. By providing a detailed examination of China's energy situation, highlighting the unique energy security vulnerabilities and threats it faces, I argue current mainstream energy security thinking in China does not match its comprehensive energy situation. It is therefore not adequate to address its energy security challenges. The thesis concludes that, a 'broader' energy security approach, going beyond the traditional thinking, should be developed to incorporate more energy sectors and domestic energy issues in China. 


\section{Acknowledgements}

One year ago, I was fortunate enough to come to the beautiful campus at Victoria University of Wellington to undertake and my Master's study. This was something I could not imagine before I graduated from China University of Political Science and Law (CUPL) in Beijing. From the beginning of the application process to the end of the thesis writing, I have become indebted to many people and institutions.

First, I would like to thank my primary supervisor, Professor Xiaoming Huang for his invaluable guidance throughout the process. Without his kind help and encouragement, it would be impossible for me to finish my Master's study in Victoria University. Also, I must give appreciation to my secondary supervisor, Dr. David Capie. He has inspired me throughout my thesis writing and has offered many useful ideas and suggestions.

Special thanks to Dr. Jason Young, for giving so much support and critique feedbacks on the thesis. Moreover, my officemates Steve Barnes and Gavin Romayne have always been ready to help me, for which I am very grateful. Appreciation also goes to several of my friends in CUPL, especially Mingzhe Zhu and Donghao Cui, who helped to inspire my research interests. Xuanwen Cheng also provided me precious encouragement throughout the study.

I would also like to thank the Political Science and International Relations Programme at Victoria University, New Zealand Contemporary China Research Centre, as well as the Political Science and Public Administration programme at CUPL. Without the kind assistance from these institutions, this thesis would not exist.

Last but most of all, thanks to my parents and sister for supporting and encouraging this endeavour in the past year, your love and support have always been the most important thing to help me overcome all kinds of difficulties in my life.

Of course, any errors in this thesis are the sole responsibility of the author. 


\section{Table of Contents}

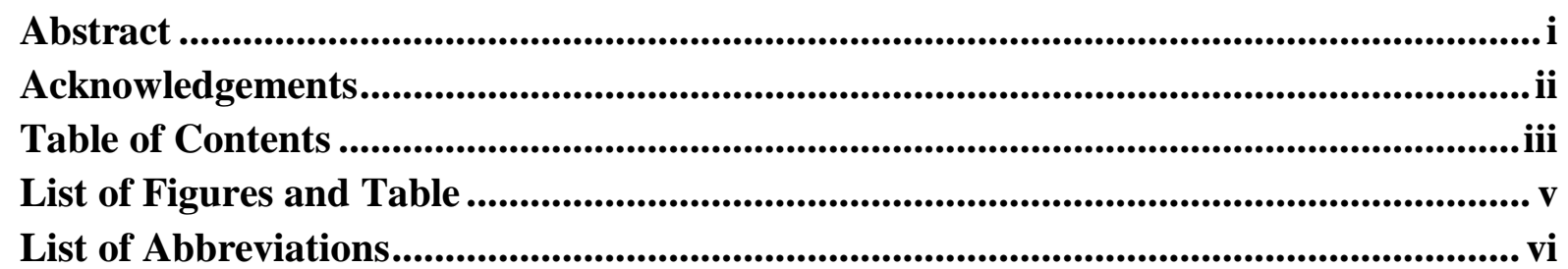

Chapter 1 Introduction ................................................................................................................ 1

Chapter 2 From Military Security to Energy Security - A Theoretical Framework ....... 7

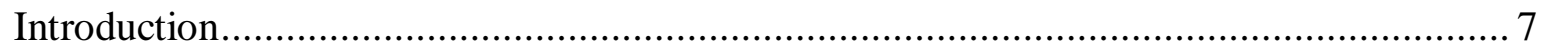

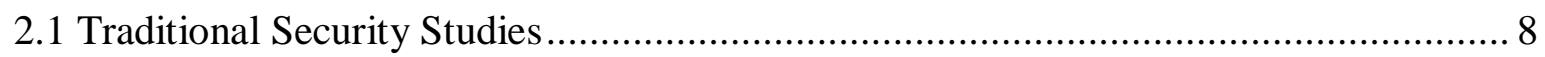

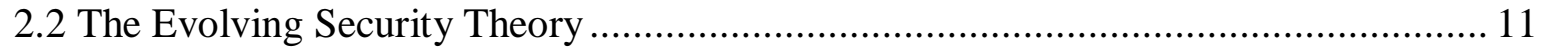

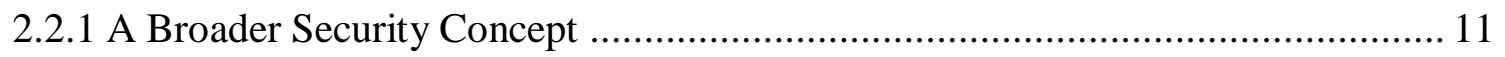

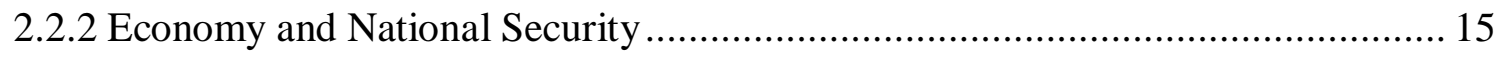

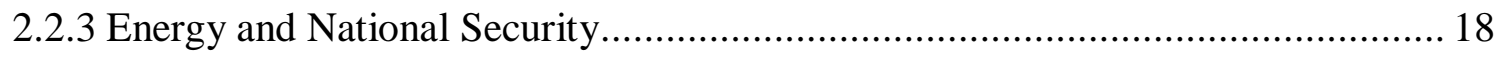

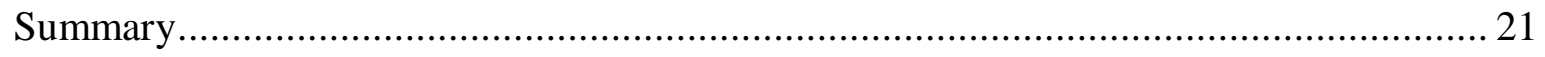

Chapter 3 A Traditional Energy Security Approach in the West ................................... 22

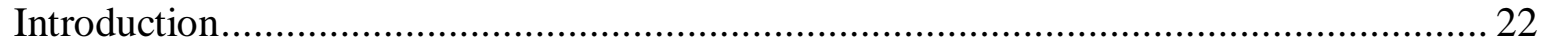

3.1 The Vulnerability of Dependence and the Threat of Crises ................................... 22

3.1.1 The Energy Situation in the United States ................................................ 23

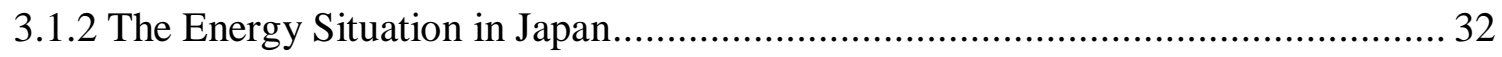

3.1.3 The Energy Situation in Western Europe ........................................................... 35

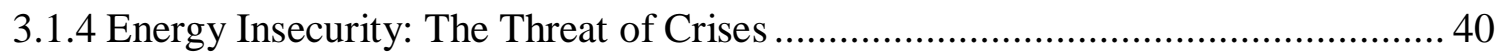

3.1.5 The Nature of Western Energy Security Issues............................................... 44

3.2 A Traditional Energy Security Approach ...................................................... 48

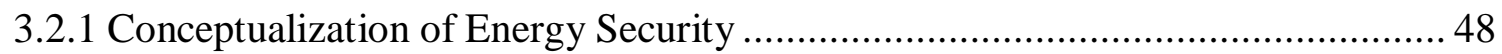

3.2.2 Strategic-Foreign Policy Responses to Energy Insecurity .............................. 50

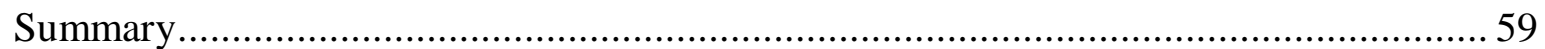

Chapter 4 Energy Security in China - Energy Situation and Energy Security Approach

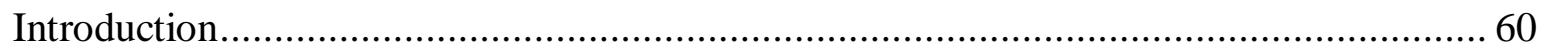

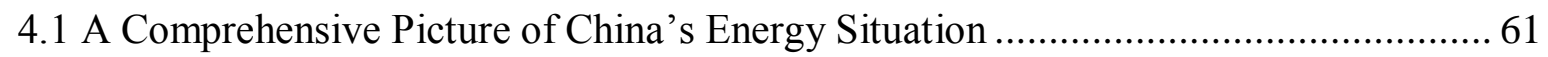

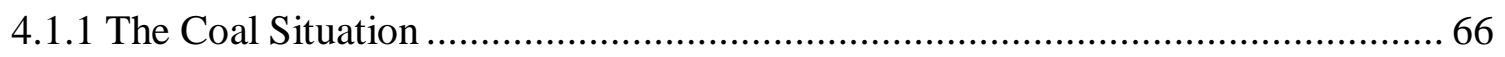

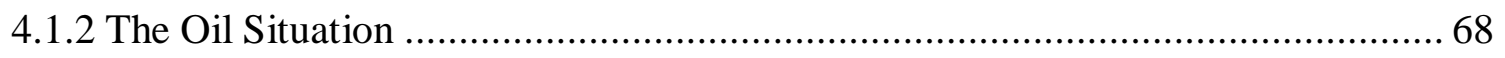

4.1.3 Other Primary Energy Sources …......................................................... 71

4.2 China's Energy Security: the Salience of the Traditional Approach ........................ 74

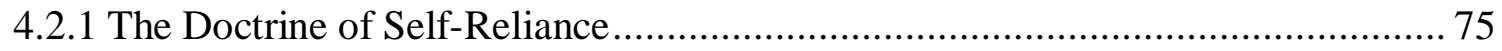

4.2.2 The Influence of the Western Approach ......................................................... 79 
4.2.3 Strategic-Foreign Policy Response to 'Energy Insecurity' ............................... 82

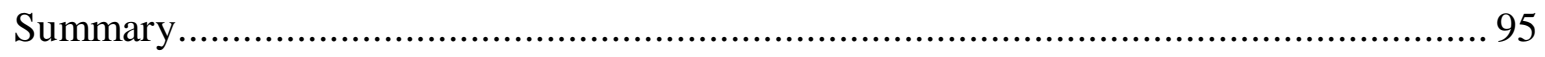

Chapter 5 Reassessing China's Energy Security .........................................................99

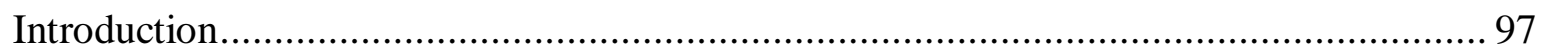

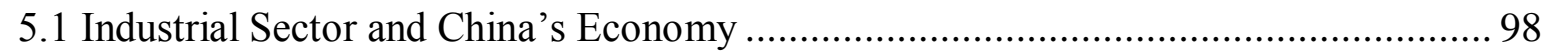

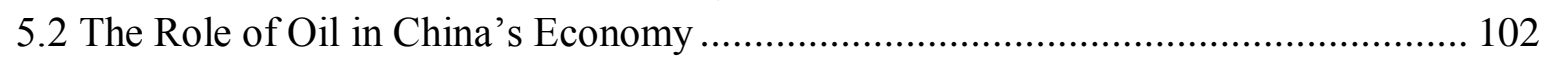

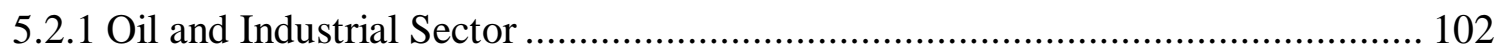

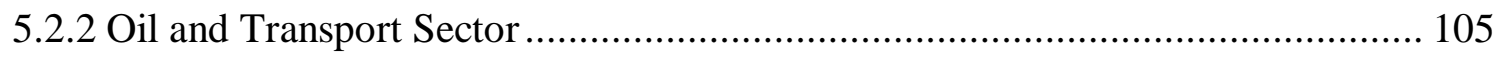

5.2.3 Oil and Agricultural, Residential and Commercial Sectors .............................. 107

5.3 The Role of Coal-based Electric Power in China's Economy .................................. 109

5.3.1 Industrial Coal and Electric Power Demands ................................................. 110

5.3.2 Coal-based Electric Power .......................................................................... 113

5.3.3 The Vital Link: Electric Power and Economy ................................................ 115

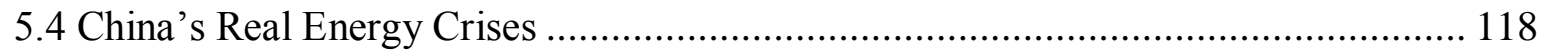

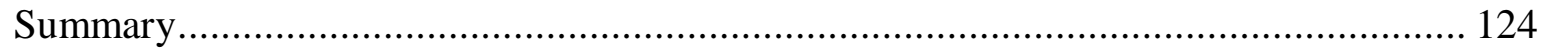

Chapter 6 Conclusion.................................................................................................... 126

6.1 The Spectrum of Energy and Security: From IWCs to China ................................ 127

6.2 Challenges to a Broader Energy Security Approach............................................... 131

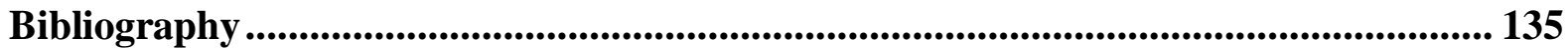




\section{List of Figures and Table}

Figure 1 U.S. Aggregate Energy Production, Consumption and Net Energy Imports,

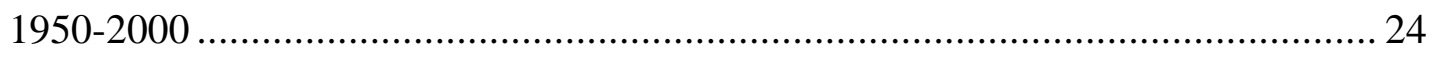

Figure 2 U.S. Primary Energy Consumption Structure, 1978 .............................. 26

Figure 3 U.S. Primary Energy Consumption Structure, 2008 ............................... 26

Figure 4 U.S. Petroleum Imports by Origin, 1970-2000 .................................... 28

Figure 5 Japan's Primary Energy Consumption Structure, 2005 ........................... 34

Figure 6 German Primary Energy Consumption Structure, 2007 ........................... 38

Figure 7 France's Primary Energy Consumption Structure, 2007 .......................... 38

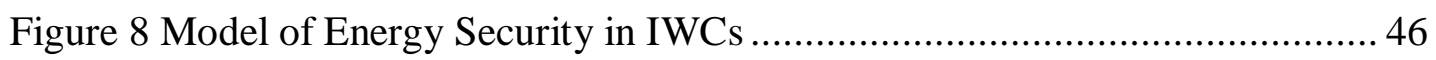

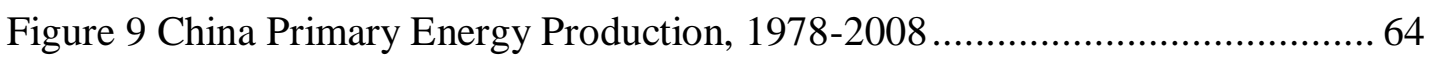

Figure 10 China Primary Consumption, 1978-2008 ..............................................6 64

Figure 11 China's Primary Consumption Structure, 2008 .................................... 65

Figure 12 Top Ten Net Oil Importers in the World, 2008................................... 70

Figure 13 China's Oil Imports by Countries of Origin, 2008 ............................... 70

Figure 14 China's GDP Composition, 1990-2008 ........................................... 100

Figure 15 China's Primary Energy Consumption by Sectors, 1995-2008 .............. 100

Figure 16 China's Primary Energy Consumption by Sector and Source, 1995-2007

Figure 17 China's Primary Energy Consumption Structure by Sources and Sectors,

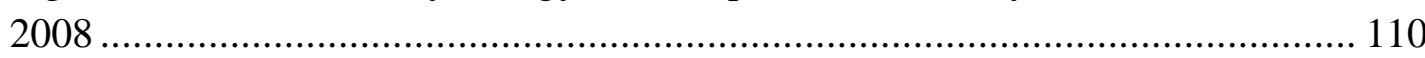

Figure 18 The Share of Direct Coal Use and Power Generation of China's Coal Consumption, 1990-2007 (Selected Years) ...................................................... 112

Figure 19 China's Electricity Generation by Fuel Sources, 1971-2007................ 114

Table 1 China's Energy Production and Consumption Over Time 63 


\section{List of Abbreviations}

bbl/d - barrels per day

BCM - Billion Cubic Meters

Btu - British thermal unit

CCP - Chinese Communist Party

CNOOC - China National Offshore Oil Corporation

CNPC - China National Petroleum Corporation

EIA - U.S. Energy Information Administration

GW - Gigawatts

IEA - International Energy Agency

IWCs - Industrialized Western Countries

Kcal - Kilocalories

KW - Kilowatt

$\mathrm{kWh}$ - Kilowatt-hours

LNG - Liquefied Natural Gas

Mmt - Million metric tons

MW - Megawatt

NDRC - (China) National Development and Reform Commission

OAPEC - Organization of Arab Petroleum Exporting Countries

OPEC - Organization of Petroleum Exporting Countries

OECD - Organization for Economic Co-operation

PRC - People's Republic of China

RMB - Ren Min Bi (Chinese currency, unit: Yuan)

Sinopec - China Petroleum \& Chemical Corporation

SLOCs - Sea Lines of Communications

SPR - Strategic Petroleum Reserve

tce - tons of coal equivalence

Tcf - Trillion cubic feet

toe - tons of oil equivalence

USD - United States Dollar

WTO - World Trade Organization 


\section{Chapter 1 Introduction}

Energy ${ }^{1}$ plays a fundamental role in society and energy security has been a long discussed issue around the world. After the Second World War, the recovery of the world economy went hand in hand with the increasing dependence on energy supply in the industrialized world (Painter, 1991). In the 1970s, two energy crises struck the major industrialized Western countries (IWCs), bringing huge impacts to their national economies (Ebinger, 1982). The high energy import dependence rate and external supply risks not only threatened their economic security, but also shaped energy security thinking and behaviors in these countries. A 'traditional energy security approach', which is characterized by a supply-sided and primarily oiloriented energy security analysis framework and the subsequent strategic-foreign policy behaviors to safeguard energy security, has been the mainstream in the IWCs such as the United States, Japan and major Western Europe countries (Fried and Trezise, 1993; Stares, 2000). This approach is deeply rooted in the common features they share in their energy situations. The huge amount of imported energy (especially oil and gas) as a key factor determining their economic performance is their main energy security vulnerability, which exposes them to the potential external energy supply risks, including supply disruptions and market volatilities.

\footnotetext{
${ }^{1}$ Energy can be divided as primary and secondary energy by different sources. Primary energy is energy found in nature that has not been subjected to any conversion or transformation process. Primary energy sources can be further divided as non-renewable energy and renewable energy. Renewable energy is energy which comes from natural resources such as sunlight, wind, tides, and geothermal heat, which are naturally replenished; Non-renewable energy is energy that comes from the ground and is not replaced in a relatively short amount of time. Fossil fuels are the main category of non-renewable energy, including coal, oil and natural gas, etc. Secondary energy is transformed from primary energy in energy conversion processes to more convenient forms of energy, such as electrical energy, refined fuels, or synthetic fuels such as hydrogen fuel.
} 
As the emerging economies' energy demands have increased sharply since the 1990s, the notion of energy security has been introduced to those economies as well. As the second largest aggregate energy consumer and second largest oil importer in the world today, China's economic growth has been largely driven by surging energy consumption over the last two decades (Ma, 2009; EIA, 2010f). Accordingly, the energy security discourse focusing on China has increased rapidly in the last two decades.

The Chinese government and academia are particularly alert to China's increasing energy demands and growing oil deficit (Cui, 2008). For China, a rising economy that has been a net aggregate energy importer for no more than two decades, energy security is a fairly new topic. Thus, to examine the nexus of energy and China's national security becomes an urgent task for both Chinese scholars and policy makers. As an influential Chinese energy security expert Erica Downs points out, the mainstream thinking on energy security in China shares the characteristics of the traditional energy security approach (Downs, 2004). A Chinese version of traditional energy security approach dominates China's energy security thinking and policy making. In other words, Chinese scholars and policy makers largely equate energy security to the security of external energy supply, especially oil supply. In a study supported by Chinese government, analysts conclude, "energy security more accurately is oil security" (Feng, et al., 2004). Thus, it seems that China's energy security issues are quite similar with that of the major IWCs. 
However, as the largest aggregate energy producer in the world and with abundant domestic supply (that can meet over 90 percent of its primary energy demands) as well as a high coal consumption (which accounts for nearly 70 percent of its primary energy consumption), China only needs to import about 10 percent primary energy to meet demand (People's Daily, Sep 27, 2009 ; OECD/IEA, 2009; NBS, 2009; EIA, 2010). Therefore, China does not share the high oil consumption and high external energy dependence features as in the major IWCs. Moreover, due to industrial sector's large contribution to its gross domestic product (GDP) and its increasing demand for coal-based electric power, China's energy-economy nexus is profoundly different with that of the IWCs. All these facts indicate that external energy supply is only a small part of China's comprehensive energy security picture.

This study begins with the assumption that a country's understanding of energy security should be based on its comprehensive energy situation. In this thesis, 'energy situation' mainly refers to the material basis of energy security thinking and behaviors in a country, including the energy consumption structure, external energy dependence rate and risks, as well as the overall energy-economy nexus in a country. By comparing the respective energy situation and energy analysis between China and IWCs, I demonstrate that, in contrast to the major IWCs that constructed their approach mainly on their energy situations, there is a gap between China's energy situation and mainstream approach. Beijing's energy security thinking and behaviors have largely been shaped by a domestic ideational factor - self-reliance - and Western energy security approach rather than being built on its own comprehensive energy situation. Therefore, with an assessment of the energy vulnerabilities and the 
threats China faces, I argue that, to employ the traditional thinking to address China's energy security is largely problematic and not adequate to comprehensively address China's energy security issues. The energy security approach in China, including the energy security concept and policy response, should be expanded to incorporate more variables such as the security of coal-based electric power supply, rather than predominantly focusing on external energy supply.

To examine China's energy security in light of security theory and to provide a comprehensive picture of its energy situation are two contributions made by the thesis. First, although energy security has existed in the academic and policy discourse for decades, this concept is rarely reflected in energy security literature (Chester, 2009). The underlying assumptions and theoretical basis of the concept have been largely overlooked. Based on the development of 'new security' theory, I argue that energy security for China is in essence an economic security issue and is therefore highly dependent on the specific energy-economy context it applies to.

Second, a significant number of analysts tend to discuss China's energy security issues without examining its comprehensive energy situation. Obsessed with energy geopolitics and foreign policy analysis, the traditional energy security approach largely overlooks the comprehensive energy situation and leads us to a limited view on China's energy security. As the material basis of energy security thinking, the energy situation largely decides the energy security vulnerabilities and the threats it faces. With a detailed examination of China's comprehensive energy situation, I 
argue that, external energy supply (mainly oil supply) is only one of the energy issues China needs to address, and not even the most urgent and problematic one.

In this thesis, detailed energy statistics are analyzed to compare the energy situations between major IWCs and China. Scholarly work, government documents and mainstream media articles are examined to reveal the energy security thinking and practices. I select the United States, Japan, Germany and France as cases of the major IWCs, mainly because they have been the major energy consumers in the world and they were the first countries to raise the energy security concept. The cases of China's nation-wide electric power shortages in the last decade are also examined to assess China's real energy situation.

The thesis is structured into six chapters. Following this chapter, Chapter Two provides a theoretical introduction of the evolving security theory and the emergence of the energy security concept in IWCs. The underlying assumptions of energy security as a national security issue are reflected in light of the new security thinking.

Chapter Three introduces the energy situations in the major IWCs, the energy supply risks (especially 1970s' energy crises) and energy security policy behaviors to examine how the heavy reliance on energy import and the supply risks shaped the traditional energy security approach. Chapter Four investigates China's energy situation and energy security approach in comparison with that of IWCs, highlighting the fact that, despite the profound differences in energy situations, 
China's energy security approach is however quite similar with that of IWCs largely due to the influence of a ideational factor and Western approach.

A reassessment of China's energy situation follows in Chapter Five. It reveals China's unique domestic energy vulnerabilities and the threats it faces, especially the coal-based economy and the economic security consequences of electric power shortages. This chapter demonstrates that China's unique energy situation makes it necessary to move China's energy thinking beyond the traditional approach, incorporating more energy sectors and expanding to domestic energy issues to address its energy insecurity.

Finally, Chapter Six summaries the key findings in the preceding chapters and the argument made here. It also includes a critical evaluation of the challenge we face to establish a 'broader' energy security approach in China. 


\section{Chapter 2 From Military Security to Energy Security - A}

\section{Theoretical Framework}

\section{Introduction}

The concept of energy security has been discussed for decades since the 1970s' energy crises, especially in the IWCs such as the United States, Japan and Western European countries. More recently, as rapid economic growth has taken place in emerging economies like China, increasing energy demands have also stimulated a discussion of energy security focusing on these economies. However, it seems that more and more scholars are discussing energy security issues without examining the nature and the theoretical context of the concept. This largely leads us to a narrow understanding of energy security which has dominated the energy security research over the last several decades (which will be critiqued in the following chapters). Thus, a central aim of this chapter is to examine energy security in the context of security studies. I argue that the concept of energy security is the result of the development of security theory since the 1970s. It is a 'new security' issue on the economic security agenda. Therefore, energy security as a scholarly concept and a policy issue should be different in countries with different energy-economy contexts.

This chapter consists of two sections. The first section outlines the origins of security studies - the traditional state/national security concept, which was built on the realist paradigm and characterized by an overwhelmingly emphasis on external 
military threats to national security. The second section examines the evolution of security studies since the 1970s and the emergence of new security issues, especially economic security and one of its earliest and most important components - energy security.

\subsection{Traditional Security Studies}

Security is a term widely used in both the analysis and practice of international relations. Dating back to the Revolutionary and Napoleonic Wars in the late 1700s and early 1800 s, the military meaning of the word 'security' came into prominence in European politics, and became understood primarily as security of state (or national security) - an objective of states to be achieved by diplomatic or military means (Rothschild, 1995). In the first decade after the Second World War, the concept of security was widely discussed by both scholars and policy makers, especially in the United States. As one of the pioneers in security studies, Arnold Wolfers characterized security as "the absence of threats to acquired values" (Wolfers, 1952: 485), which seems to capture the basic intuitive notion underlying most uses of the term security.

However, only from the early 1960 s did the intellectual and institutional developments in the social sciences allow scholars to begin to examine the nature of national security as an analytic concept. In this period, security studies were based on the political context that realist schools offered, that is, the need for states to survive and increase power in an anarchical world. As the basic unit in international 
anarchy, individual states have always been the legitimate referent object in security studies. A national security tradition has been thus established in security studies. National security is commonly perceived as "the ability of a nation to protect its internal values from external threats" (Bock and Berkowitz, 1966: 134).

The origins of this interpretation on national security can first be found in historical formulations of the concept of national interests. In the realist paradigm, whatever attempts were made almost always equated national interest with the quest for power. According to Hans Morgenthau, the only clear meaning that can be assigned to the national interest is the fact that nations always act, or should act, to maximize their power positions in the international system (Bock and Berkowitz, 1966). This was foreshadowed even earlier by Walter Lippmann, who wrote, "A nation has security when it does not have to sacrifice legitimate interests to avoid war, and is able, if challenged to maintain them by war" (Lippmann, 1950: 51).

Walter Lippmann's words also reveal the nature of security threats and the means to achieve national security. Traditionally, the notion of national security focused on the phenomenon of war and on military balances (Walt, 1991). Security was developed around military capabilities, and the central questions in this field were concerned with international violence and other threats to the security of states (Nye and Lynn-Jones, 1988). Charles Reynolds, for instance, emphasised that security only exists when a state possesses the capacity to fight successful wars against any potential aggressor, and defence policy is concerned mainly with relative military capacities (Reynolds, 1973: 179-80). Under realist paradigm, all states are basically 
the same type of object, each responsible for its own security. Therefore the primary concern of the state is self-protection.

From the mid-1960s, traditional studies of state security were driven into a 'Golden Age' by two events - the twin revolutions in American foreign policy and military technology development of atomic weapons (Nye and Lynn-Jones, 1988; Walt, 1991). During this period, studies were dominated by nuclear weapons, arms control and warfare, and the critical question was "how could states use weapons of mass destruction as instruments of policy, given the risk of any nuclear exchange" (Baldwin, 1995: 123). Deterrence theory and game theory were arguably the major achievements in the history of security studies in international relations during this period (Nye and Lynn-Jones, 1988; Baldwin, 1995).

From the mid-1970s to 1980s, state security was further developed by incorporating insights from many new disciplines, such as history, psychology, and organization theory (Walt, 1991). However, by the early 1990s, Stephen Walt still re-emphasized that security studies should only involve "the study of the threat, use and control of military force" (Walt, 1991: 212). He argued that expanding security studies to such non-military issues as economy and environment

would destroy its intellectual coherence and make it more difficult to devise solutions to any of these important problems.... any attempt to understand the evolution of the human society, let alone the prospects for peace, must take account of the role of military force. Indeed, given the cost of military forces and the risks of modern war, it would be irresponsible for the scholarly community to ignore the central questions that form the heart of the security field.

(Walt, 1991: 213) 
In sum, there are two features that stand out about the traditional concept of national security. First, the threat to national security or the origin of national insecurity is mainly external military aggression. Second, state security needs to be achieved through the balance of military power and foreign policy. Nevertheless, the meaning of 'security' has been questioned since the mid-1970s.

\subsection{The Evolving Security Theory}

\subsubsection{A Broader Security Concept}

Since the mid-1970s, the traditional concept of national security has been challenged by a variety of issues. With the deepening economic, environmental and societal troubles in IWCs, it has been argued by many security scholars that the threat to national security is not only from military aggression but also from other sectors.

Richard H. Ullman argues that "defining national security merely in military terms conveys a profoundly false sense of reality" (Ullman, 1983: 129). For him, a threat to national security is "an action or sequence of events" that "threatens drastically and over a relatively brief span of time to degrade the quality of life for the inhabitants of a state", or "threatens significantly to narrow the range of policy choices available to the government of a state or to private, nongovernmental entities within the state" (Ullman, 1983: 133). Such threats can encompass external and internal conflicts as well as blockades and boycotts, and natural disasters. 
Echoing the academic discussion, governmental organizations such as the United Nations also assert the idea of broadening the security agenda. For example, the UN group of experts on disarmament and developments states boldly in the report The Relationship between Disarmament and Development:

Security is a wider concept than that of military security alone. Economic as well as social aspects of this problem are of great importance... The range of contemporary challenges to the security of nations is far broader than military power of the potential adversaries. One can mention here the pronounced and almost universal drop in average rates of economic growth, looming scarcities of many vital raw materials and commodities, mounting concern over the long-term effects of environmental degradation and persuasive demand for a more just and equitable distribution of the world's wealth and opportunity.

(UN, 1982)

A series of articles has also been published since the early 1980s, with the purpose of redefining and broadening the neo-realist conception of security to cover a wider range of potential threats, from economic and environmental problems to human rights and migration. Within the discussions and debates on the broader concept of national security, the major shift is marked by Barry Buzan's People, States and Fear, which was first published in 1983 (then the second edition was published in 1991). It is commonly perceived that Buzan develops a broader concept and a wider international context for the study of security than that offered in the traditional national security concept (Booth, 1991). Two features of Buzan's theory are in particular important comparing with the traditional security studies. 
First, Buzan defines the broadened security agenda in terms of security threats from different sectors. He contends that the security agenda involves not only military security, but also political, economic, social and ecological sectors, and these five factors are all "woven together in a strong web of linkages" (Buzan, 1991: 19). According to Buzan, military security concerns "the two level interplay of the armed offensive and defensive capabilities of states, and states' perceptions of each other's intensions" (Buzan, 1991: 19). Political security refers to "the organizational stability of states, systems of government and the ideologies that give them legitimacy". Economic security entails "access to sustain acceptable levels of welfare and state power". Societal security concerns "the sustainability, within acceptable conditions for evolution, of traditional patterns of language, culture and religious and national identity and custom". Environmental security covers "the maintenance of the local and planetary biosphere as the essential support system on which all other human enterprise depend" (Buzan, 1991: 19-20).

Second, in contrast to traditional security thinking, the nature of national security issues is different from country to country. Running against the orthodox view under the realist paradigm that all states are essentially the same, Buzan contends that states are exceedingly varied despite their fundamental similarities (Buzan, 1991: 97). In Buzan's view, there are three component parts of a state: the physical base of population and territory; the institutions to govern the physical base; and the idea of the state which establishes its legitimacy in the minds of its people. Each of the three components presents itself in a wide variety of options. When combined, these result in an open-ended array of combinations around which a state might be structured. 
Because of this diversity, the particular nature of security issues differs substantially from state to state.

According to Buzan, "Insecurity reflects a combination of threats and vulnerabilities", and "only when one has a reasonable idea of both the nature of threats, and the vulnerabilities of the objects towards which they are directed, can one begin to make sense of national security as a policy problem" (Buzan, 1991: 112). Then he goes on to state

this distinction between threats and vulnerabilities points to a key divide in security policy, namely, that states can seek to reduce their insecurity either by reducing their vulnerability or by preventing or lessening threats. These alternatives underline, respectively, the ideas of national and international security. In other words national security policy can either focus inward, seeking to reduce the vulnerabilities of the state itself, or outward, seeking to reduce external threat by addressing its sources.

(Buzan, 1991: 112)

This is in sharp contrast with the traditional security thinking which assumes all states are basically the same and the security concept could be applied universally. A broader security agenda should not only expand the sectors where security issues exist, but also requires scholars to examine the specific international and domestic contexts of security issues. The threats to national security could be either mainly external factors or domestic problems to a certain country, and therefore the focus of academic research and government policy responses should be different accordingly. 
This core characteristic of 'new security' thinking needs to be taken into when we study the new security issues such as economic security.

\subsubsection{Economy and National Security}

As one of the sectors under the broader security agenda, economic security was the first challenge to traditional national security concept. As early as 1975, Lawrence B. Krause and Joseph S. Nye raised the concept of economic security. They define economic security as "the absence of acute threats to the minimal acceptable levels of the basic values that a people consider essential to its survival" and identify three basic clusters of values: welfare (including a minimal level of economic welfare), independence, and prestige or political status. Further, they proposed a concept of economic security, which they defined as the "absence of threat of sever deprivation of economic welfare" (Krause and Nye, 1975: 330-331).

Giacomo Luciani raises the issue of separating two kinds of economy-security nexus, namely "the economic content of territorial security", and "the economic content of security broadly defined" (Luciani, 1988). The former refers to the economic base of national defence, which is a limiting factor placed upon a nation's ability to deploy military capabilities by its economic capacity; the latter means "to the extent that domestic consensus and political stability are reinforced by economic prosperity, a deterioration of economic conditions may be perceived as a threat to national security. To the extent that material means are part and parcel of the 
definition of essential values, then changes in economic conditions affect national security" (Luciani, 1988: 154).

Vincent Cable further identifies four approaches to define economic security. First, similar to Luciani's idea, economic security can refer most obviously to those aspects of trade and investment which directly affect a country's ability to defend itself. A second approach is in terms of economic policy instruments which are used for purpose of aggression, including trade and investment boycotts, the restriction of energy supplies, etc. In this approach, economic security tends to be simplified as 'security of supply'. The Arab oil embargo in the first energy crisis during 1973-74 is a typical example. A third usage is the idea that the projection of power of a state may be undermined by relatively poor economic performance and requires an economic policy response. Finally, an even looser concept of economic security captures the fear of the overall economic, social and ecological instability (Cable, 1995: 306-307).

The second economy-security nexus indentified by Luciani and the latter two approaches raised by Cable are much broader and comprehensive, concerning the link between the economy and the overall power of the state within the international system. The decline of an economy, which can result as much from internal as external causes, will inevitably affect the state's power. In the argument made famous by Paul Kennedy, all of recorded history is a relentless catalogue of rising and declining powers. Relative economic growth plays a major role in determining the power of states in the system, and is thus a key aspect of national security 
(Kennedy, 1988). Economic capability is the crucial foundation on which the relative status of great powers in the system rests. Thus in times of intense power rivalry relative economic performance may come to be perceived as a national security issue regardless of the sense or wisdom of doing so. For example, until the 1980s the United States feared that prospect of Soviet economic success providing a power base large enough to overwhelm American influence.

Echoing Buzan's theory emphasizing the nature of security issues differs due to the diversity of states, the notion of economic security is in fact more like a spectrum from 'narrow' to 'broad'. The narrow end represents the economic content of a military security orientation (the economic basis for a state's military power); the broad end views economic security as a factor determining the economic competitiveness and comprehensive power of a state. Countries with different energy-economy situations are likely to find that they have different vulnerabilities and face different threats and therefore place themselves on different positions of this spectrum. However, it is fair to say that the basic nexus between economy and security is stable, namely the importance of economic development, in particular the growth of gross domestic product (GDP) to national security (Pinder, 1984; Gelb, 2010). In the 1970s when the traditional security concept was challenged, one of the most urgent problems in the Western industrialized countries was the economic recession (especially 'stagflation' in the U.S.) caused by the energy crises. Thus, energy security became the first issue on the economic security agenda. 


\subsubsection{Energy and National Security}

Energy plays a fundamental role in shaping the economy or even the overall human condition. People's needs for energy are essential for survival. Energy production and consumption are thus some of the most important activities in an economy. Indeed, it has been argued that energy is the key to the advance of civilisation, that the evolution of societies is dependent on the conversion of energy for human use. Energy features mainly as an input of economic processes and as an intermediate good. In other words, energy is usually valued as an input into some process of production or utilization which results in a final product of other things. The input of energy to the economy is necessary in the production of commodities (Boulding, 1973).

Ever since the industrial revolution, the world has witnessed the increasing dependence of the advanced industrial economies on fossil fuels, first coal, then oil, as their major energy source due to the continuous development of modern industries. The link between national security and energy was first identified by advanced industrialized nations during modern warfare, as a military logistic and strategic resource issue. On the eve of World War I, First Lord of the Admiralty Winston Churchill made the decision to shift the power source of the British Navy's ships from coal to oil. He intended to make the fleet faster than its German counterpart. But the switch also meant that the Royal Navy would be reliant on oil supplies from what was then Persia instead of the coal from Wales (Yergin, 2006:

69). During World War II, Japan and Germany's strategy to occupy energy 
producing countries and regions, such as Rumania and Indonesia, again demonstrated energy as a crucial strategic resource in modern warfare. In fact, the oil embargo that the United States imposed on Japan was a key factor in triggering the war in Pacific (Gilpin, 1977). However, this view of energy and national security still falls in the realm of military security rather than economic security.

Due to the unbalanced geographical distribution of energy resources worldwide and the increasing energy consumption driven by the industrialization, the major industrialized states became increasingly dependent on energy resources beyond their territories after WWII, especially fossil fuels. The consumption of fossil fuels were built into their development model through the popularity of private automobiles, booming transport sector and manufacturing industries, the link between energy and security seen by scholars and policy makers in these countries moved beyond the traditional security concerns. Thus, the threat of energy supply interruptions and consequently sharp increase in energy prices that could impose heavy economic and political costs to the Western countries occurred repeatedly in the 20th century.

In the 1970s, energy security studies were mainly focused on the empirical evidence of the two energy crises that suggested that the interruption of energy supply may have a large negative effect on energy dependent countries' economic performance and thus threaten the national security. A large body of empirical literature since the mid-1970s has explored the consequences of energy supply disruptions and energy 
price volatilities. This literature argues that energy shocks were both significant determinants and exogenous to the energy importing countries' economic activity in the post-WWII period by bringing negative impacts, leading to recessions, lower GDP growth and inflation in energy dependent countries (Rasche and Tatom, 1981; Hamilton, 1983; Burbidge and Harrison, 1984; Hamilton, 1985; Santini, 1985; Gisser and Goodwin, 1986; Loungani, 1986; Tatom, 1988; Mork, 1989; Hamilton and Herrera, 2004; Aguiar-Conraria and Wen, 2007). Additionally, in a Cold War background when domestic economic performance largely affected the balance of power between the East and the West, energy was inevitably deemed as a key national security issue which required policy response among the Western governments.

For most of the IWCs, the biggest energy security vulnerability is undoubtedly their high energy import dependence, especially when the bulk of their energy demands are dependent on several key energy producers concentrated in a certain region (mainly Middle East) that has suffered from unstable geopolitical situation in the last decades. This dependence makes the major Western energy consumers vulnerable to the threats in several ways. First, they are vulnerable to the use of economic means as strategic leverage by energy producers, that is, the utilization of a state's or a energy cartel's control over energy needed by another state to induce the behavior changes in the energy dependent state. Second, they are vulnerable to hostile powers' military or diplomatic means to block or interrupt the energy supplies from the key energy producers. Third, the unstable domestic and regional geopolitics is likely to result in energy supply disruptions, which will also push up international 
energy prices. Thus, the vulnerability of dependence and these external threats constitute the basic context where the energy security thinking existed in the West, which will be analyzed in details in the following chapter.

\section{Summary}

Traditionally the concept of security was developed around military capabilities, and the central questions were concerned with international violence and other threats to the security of states. More importantly, since all states are viewed basically as the same type of object, the concept of security was found valid universally. However, since the mid-1970s, the traditional concept of national security has been challenged. Many security scholars argued for the expansion of the security concept from a military focus to a wider range of issues, especially economic concerns. Barry Buzan contends that states are exceedingly varied despite their fundamental similarities, and the particular nature of security issues differ substantially from state to state. Therefore, in contrast to the traditional security concept, the 'new security' thinking requires detailed examination of the contexts where the security issues exist before seeing them as a policy issue in different countries.

With the economic troubles that hit the industrialized world in the early 1970s, economic security was the first new security issue that came into the scope of new security studies. This economic security agenda was mainly rooted in the impact brought by the problematic energy-economy situation of the Western energy importing countries in the 1970s. Thus, the notion of 'energy security' began to emerge as an economic security issue and a set of energy security thinking, reflecting in the energy security concepts and policies, was established in the major IWCs. 


\section{Chapter 3 A Traditional Energy Security Approach in the West}

\section{Introduction}

The concept of energy security was first raised by the major industrialized Western countries (IWCs), which have also been the major energy consumers as well as importers since the WWII (EIA, 2010a). In this chapter, by analyzing the energy situations, energy security thinking and the subsequent policy responses in the United States, Japan and Western Europe, I argue that the main energy security concern in these countries has always been the insecurity of external energy supply. Their similar energy security approach was firmly constructed upon the common features they share in their respective energy situations, namely the vulnerability of high energy import dependence, and the threats of supply disruptions and the market volatilities. Therefore, these countries had to develop an oil-oriented and external supply-sided traditional energy security approach which is characterized by a traditional energy security concept and the subsequent strategic-foreign policy response to address their energy insecurity.

\subsection{The Vulnerability of Dependence and the Threat of Crises}

Since the industrial revolution, the world has witnessed the increasing dependence of the advanced industrialized economies on energy resources, especially fossil fuels. 
This dependence began with the eighteenth century introduction of steam power to English coal mines. Consequently, the use of steam power from coal permanently established the link between fossil energy resources and industrialization (Ian Barbour, et al., 1982). In the early twentieth century, due to the invention and spread of combustion engine technology, steam power was rapidly replaced by engine power. Thus oil became increasingly important to industrialized economies. Because of the unbalanced geographic distribution and increasing consumption of oil (and to a less extent, natural gas), these countries' energy import dependence also increased in most of the 20th century, which made them vulnerable to external supply risks.

\subsubsection{The Energy Situation in the United States}

As the leader of the West and the largest energy consumer in the world, the United States has also been the leader in both energy security studies and policy practice in the last decades. Additionally, in contrast to other economies in this chapter, the United States is not only the biggest energy consumer and importer, but also a major energy producer. Its energy situation is therefore the most similar with China's (which will be analyzed in the following chapters) among the IWCs.

America's demand for energy as it industrialized was prodigious. The aggregate primary energy consumption roughly quadrupled between 1880 and 1918 (EIA, 2010a). Coal fed much of this growth, while secondary energy source like electricity expanded in applications rapidly. Oil experienced major boosts with the discovery of Texas's oil fields at the beginning of the 1900s and with the advent of mass- 
produced automobiles. For much of its history, the United States was self-sufficient in energy. By the late 1950s, production and consumption of energy were nearly balancing. Over the following decade, however, consumption gradually outpaced domestic production and by the early 1970s a significant gap had developed (See Figure 1).

Figure 1 U.S. Aggregate Energy Production, Consumption and Net Energy Imports, 1950-2000²

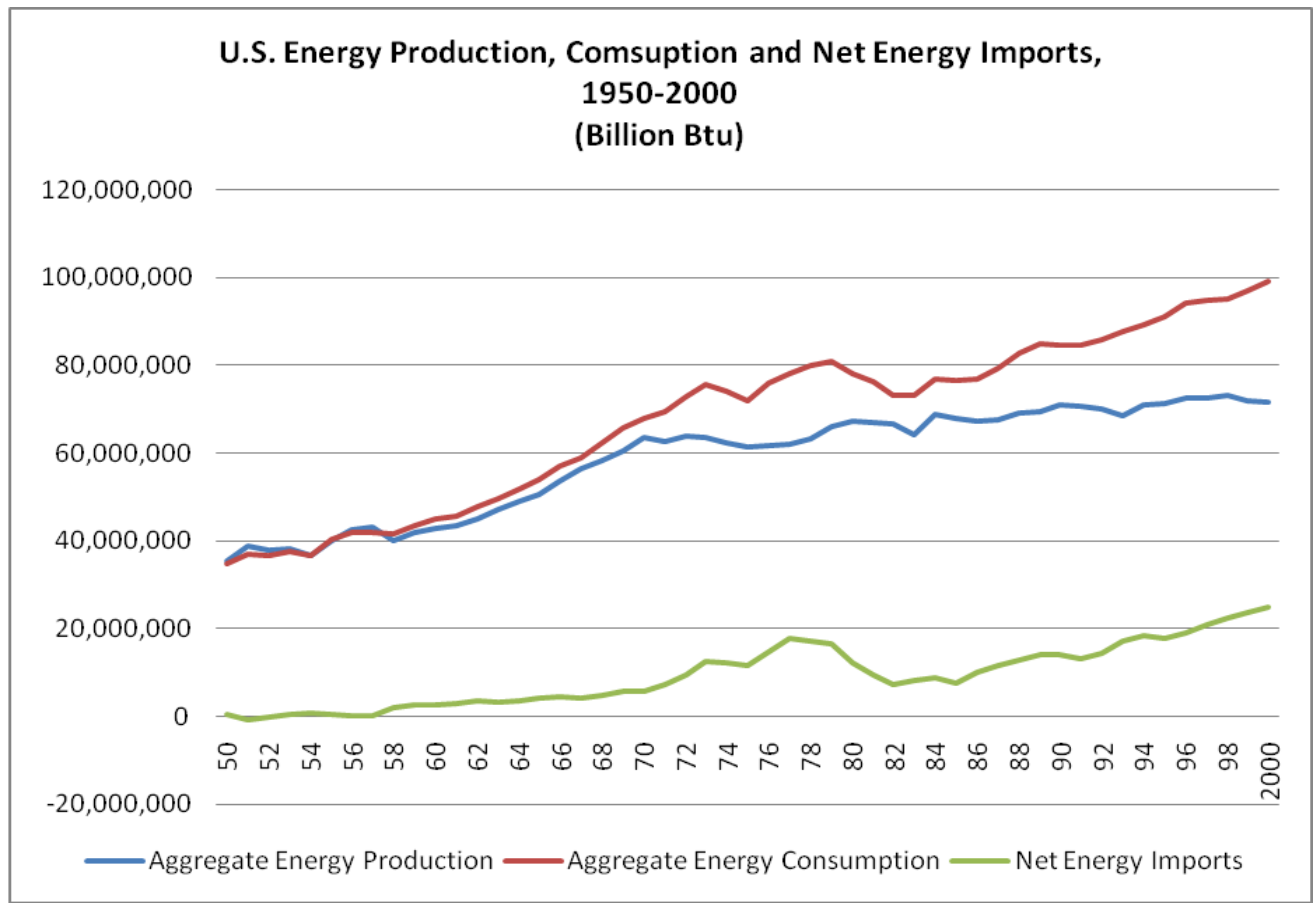

\footnotetext{
${ }^{2}$ Data Source: EIA. "Historical Energy Data". U.S. Energy Information Administration. Accessed in
} August, 2010, http://www.eia.doe.gov/emeu/aer/eh/eh.html. 
Today's primary energy consumption structure in the United States has not changed much from the 1970s (See Figures 2 and 3), except for the declining share of oil and the rising share of coal and nuclear power (which is largely in response to the 1970s' energy crises). Oil and gas, the two primary energy sources, are still imported in substantial quantity, supplying about 61 percent of its total energy consumption. The third of the largest sources of primary energy, coal, is available from abundant domestic sources. Remaining sources including nuclear power, and renewable energy sources, including biomass (wood waste and bio-fuels), hydroelectric power, geothermal, solar and wind power. According to the World Bank, in 2007, about 29 percent of U.S. primary energy demands needed to be imported (WDI, 2010). 
Figure 2 U.S. Primary Energy Consumption Structure, $1978^{3}$

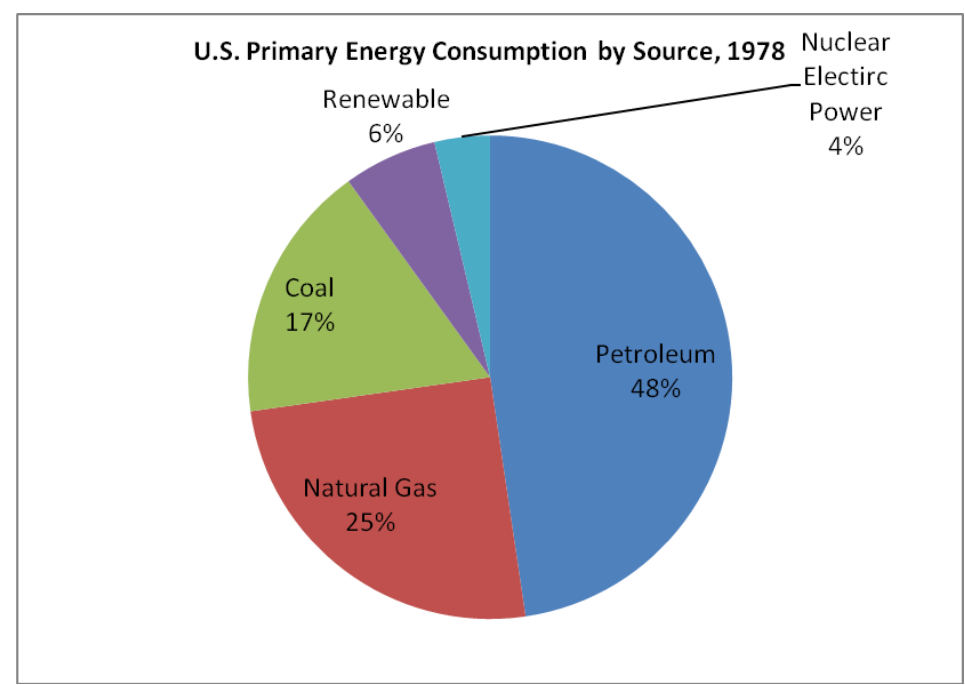

Figure 3 U.S. Primary Energy Consumption Structure, 2008 $^{4}$

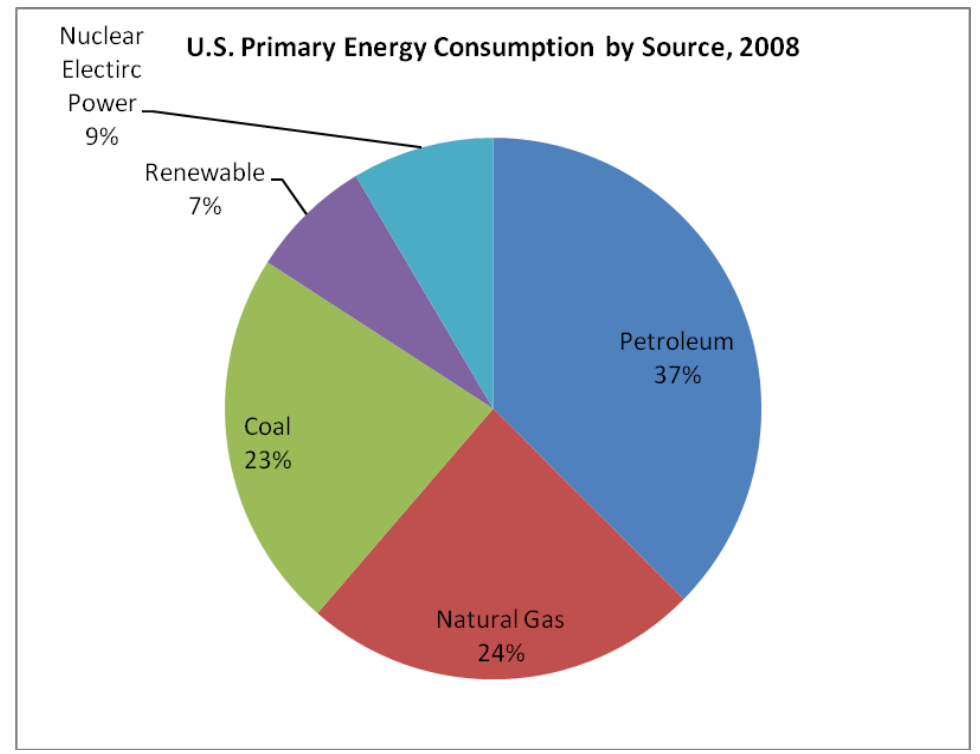

${ }^{3}$ Data Source: EIA. "U.S. Primary Energy Overview 1949-2009". U.S Energy Infomation Administration. Accessed in August, 2010, http://www.eia.doe.gov/aer/txt/ptb0101.html.

${ }^{4}$ Ibid. 
The United States dominated world oil production during the first half of the twentieth century, with its oil fields accounting for slightly more than 70 percent of world production in 1925 and over 50 percent in 1950 (Painter, 1991: 197). But by 1965 the US share of crude oil production fell far short of domestic demands, requiring the country to rely on imported supplies (See Figure 1). Over the last fifty years, the United States' consumption of oil has grown continually except for a time after the second energy crisis during the late 1970s and mid-1980s. Whereas consumption has generally risen ever since the early 1970s, oil production has been in decline in all the domestic oil fields (except in Alaska). As a result, net imports of oil increased steadily through 1970 s, declined from then until 1982, and have been growing ever since (EIA, 2010a) (See Figure 4).

When the United States' crude oil production peaked at 9.6 million barrels per day (bbl/d) in 1970, net imports stood at 3.2 million bbl/d (EIA, 2010a). On the eve of the first energy crisis in 1973, the United States' total energy production was 63.6 Quadrillion British thermal unit (Btu) ${ }^{5}$, while its total energy consumption was 75.7 Quadrillion Btu, the net energy imports is almost exclusively made up of petroleum, accounting about 16 percent of its total energy consumption. The petroleum imports from Organization of Petroleum Exporting Countries (OPEC) $)^{6}$ countries accounted for about 48 percent of its oil import, which means almost 8 percent of the United

\footnotetext{
${ }^{5}$ The British thermal unit is a traditional unit of energy equal to about 1055 joules. One Quadrillion Btu equals to the amount of energy in 45 million tons of coal, or 1 trillion cubic feet of natural gas, or 170 million barrels of crude oil.

${ }^{6}$ OPEC (Organization of Petroleum Exporting Countries) is an energy cartel made up of twelve oil exporting countries: Algeria, Angola, Ecuador, Iran, Iraq, Kuwait, Libya, Nigeria, Qatar, Saudi Arabia, the United Arab Emirates, and Venezuela. OPEC has maintained its headquarters in Vienna since 1965, and hosts regular meetings among the oil ministers of its Member Countries. Indonesia withdrew in 2008 after it became a net importer of oil.
} 
States' total energy consumption in 1973 depends on the oil supplies from OPEC members (EIA, 2010).

Despite the huge impact of the first energy crisis in 1973-74, the oil dependence continued to grow throughout the decade. At its peak in 1978, just before the second energy crisis, the petroleum imports accounted for 22 percent $(8.4$ million bbl/d) of its total energy consumption, out of which OPEC oil accounted for as high as 70 percent, meaning that 15.4 percent of United States total energy consumption depended on OPEC oil supply, almost doubled that of 1973. Iran's oil supply alone accounted for 6 percent of its oil imports in 1978 (EIA, 2010) (See Figure 4).

Figure 4 U.S. Petroleum Imports by Origin, 1970-20007

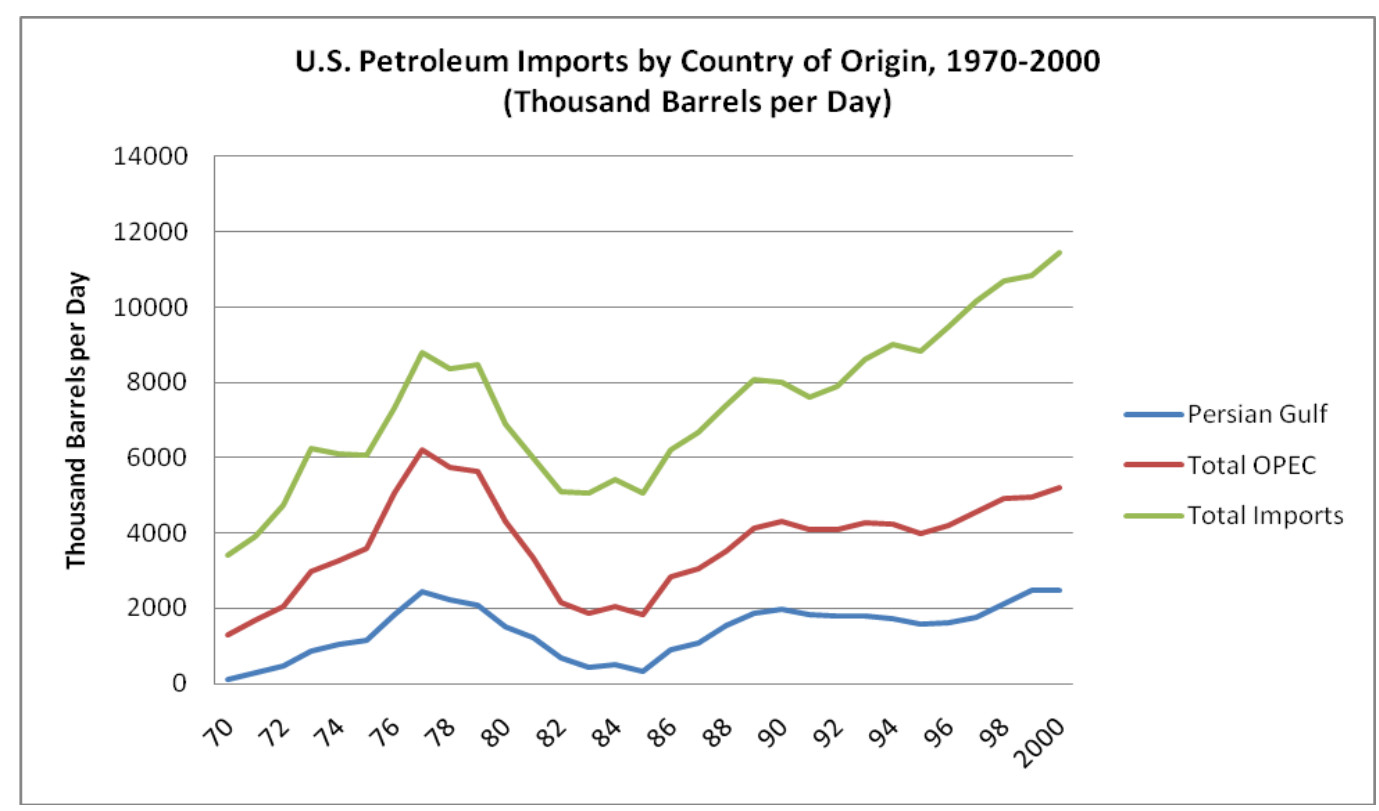

\footnotetext{
${ }^{7}$ Data Source: EIA. "Historical Energy Data".
} 
U.S. policy makers became alarmed in the 1970 s as oil imports rose to 50 percent of total oil consumption and sought successfully to reduce demand and thus imports to about one-third of consumption. However, the oil consumption has been growing rapidly since. By 1996, the United States' net oil imports exceeded production for the first time. In 2008, its domestic production was 6.7 million bbl/d, while net imports were 11.0 million bbl/d, making it the largest oil importer in the world (EIA, 2010b).

In United States, most (71 percent) oil is consumed by transport sector, and oil provides 95 percent of transportation energy needs. ${ }^{8}$ This domination of oil in the transport sector is the result of its relatively low cost across time, and its convenience as a high-energy-density liquid that is easy to store and transport. It is the dependence of the transportation system on liquid fuel that makes oil so important to the United States' economy (EIA, 2010b). This is also true for most of the industrialized economies.

In contrast to oil, natural gas is more evenly split among end users. Factories, manufacturing plants and other industrial customers are the main consumers of natural gas. A similar situation exists in other industrialized economies. In 2008, natural gas accounted for 24 percent of United States' primary energy consumption, making it the second largest energy source (See Figure 3). About 22 Trillion cubic feet (Tcf) of natural gas were used in the country in 2008, making it the largest natural gas consumer worldwide (AGA, 2010). According to the U.S. Energy

\footnotetext{
${ }^{8}$ The remaining supply comes from natural gas, alcohol fuels produced mainly from corn, and small amounts of electricity.
} 
Information Administration's International Energy Outlook, the United States typically accounts for 20 to 25 percent of total worldwide consumption of natural gas (EIA, 2010).

United States was once self-sufficient in natural gas, but after 1967 natural gas consumption began to significantly outpace production in the U.S.. Imports rose rapidly to make up the difference, nearly all (90 percent in 2008) coming by pipeline from Canada, although small volumes were brought in by tanker in liquefied form from Algeria and, in recent years, from a few other countries as well (EIA, 2010d). ${ }^{9}$

In many ways, the industrial revolution of the United States was actually fuelled by coal. However, as the industrialization proceeded in the late $1800 \mathrm{~s}$, coal's importance declined significantly. Today, behind natural gas, coal is the third largest energy source in the United States, accounting for 23 percent of total primary energy consumption in 2008 (BP, 2008).

In terms of end use, almost 93 percent of coal was consumed by the electric power generation sector in 2008, which means about 21 percent of U.S. electric power was converted from coal. In 2008, the country generated 4,119 billion Kilowatt-hours $(\mathrm{kWh})$ electricity with a total installed capacity of 1088 Gigawatts $(\mathrm{GW})$, with 49 percent from coal-fired (also known as conventional thermal) plants, 22 percent from gas and 6 percent from hydro. About half of U.S. total installed power generation capacity was coal based conventional thermal plants. Among the rest of

\footnotetext{
${ }^{9}$ These countries are Mexico, Egypt, Nigeria, Norway, Quatar and Trinidad.
} 
the coal demand, two percent went to coke plants, ${ }^{10}$ five percent went to other industrial sectors and only less than one percent was consumed by commercial and residential sectors (EIA, 2010e).

Despite a halt in the construction of new nuclear power plants for more than 30 years, reliance on nuclear power has continued to grow in the United States. In 1980, nuclear plants produced 251 billion kWh electricity, accounting for 11 percent of the country's total electricity generation. In 2008, that output had risen to 805 billion $\mathrm{kWh}$, which was 20 percent of total electricity generated nationwide, providing more than 30 percent of the electricity generated from nuclear power worldwide (WNA, 2010). Much of the increase came from the 47 reactors, all approved for construction before 1977, that came on line in the late 1970s and 1980s, more than doubling US nuclear generation capacity. Among 4,119 billion KWh electricity the country generated in 2008, nuclear power stations contributed 805 billion KWh, accounting for almost 20 percent (WNA, 2010).

Although being developed rapidly, renewable energy sources accounted for only six percent of total primary energy consumption in 2008. Among the renewable energy consumed in 2008, biomass contributed half (53 percent); Hydroelectric power accounted for 34 percent; Wind is the fastest growing renewable source, but only contributed seven percent; Geothermal was five percent and Solar one percent (EIA, 2010).

\footnotetext{
${ }^{10}$ Coke is the solid carbonaceous material derived from destructive distillation of low-ash, low-sulfur bituminous coal. It is mainly used in iron and steel industry as a fuel and as a reducing agent in smelting iron ore in a blast furnace.
} 
As the most powerful industrialized Western country, the United States economy has been traditionally heavily dependent on imported fossil energy, especially oil. Moreover, the origins of imported energy geographically concentrate in the Middle Eastern OPEC member countries. However, compared to the energy situation in Japan and Western Europe, U.S. energy import dependence is much more modest.

\subsubsection{The Energy Situation in Japan}

During the last century, Japan has experienced dramatic changes in economic and social structure. Energy consumption in Japan has also risen drastically since. Between 1900 and 2000, primary energy consumption per capita expanded by about 18 times, from 2.4 million Kilocalories (kcal) to 44.0 million kcal. This growth was also much faster than other advanced industrialized countries (Hunt and Ninomiya, 2005).

In 2008, as much as 84 percent of total primary energy demands in Japan depended on energy imports, including all the fossil fuels it needed (WDI, 2010). As shown in Figure 5, oil accounted for almost half of Japan's total energy consumption. The Japanese government's 2006 New National Energy Strategy emphasized that the country should reduce its share of oil consumed in its primary energy mix as well as the share of oil used in the transport sector. The share of oil in total primary energy demands has fallen from roughly 80 percent of the energy mix in the 1970 s to roughly 50 percent today, which has been made possible by increased energy efficiencies and the expanded use of nuclear power and natural gas. Coal continues 
to account for a significant share of total energy consumption, although natural gas and nuclear power are increasingly important sources, particularly as Japan pursues environmental policies. Japan is the third largest consumer of nuclear power in the world, after the United States and France. Hydroelectric power and renewable energy account for a relatively small percentage of total energy consumption in the country (EIA, 2010).

Throughout the 1960s and 1970s, its dependence on imported oil became more marked as a result of the availability of cheap oil and changes in the Japanese economic structure in favor of oil-using products and technologies. As a result imported oil came to supply a growing proportion of Japan's primary energy requirements - 37 percent in 1960, 71 percent in 1970, and 76 percent by 1978 (Yorke, 1981: 435). As mentioned above, although Japan successfully reduced the share of oil to about half of its primary energy consumption, the country has been the second-largest net importer of crude oil (5 million bbl/d) worldwide for decades (EIA, 2010). 
Figure 5 Japan's Primary Energy Consumption Structure, $2005^{11}$

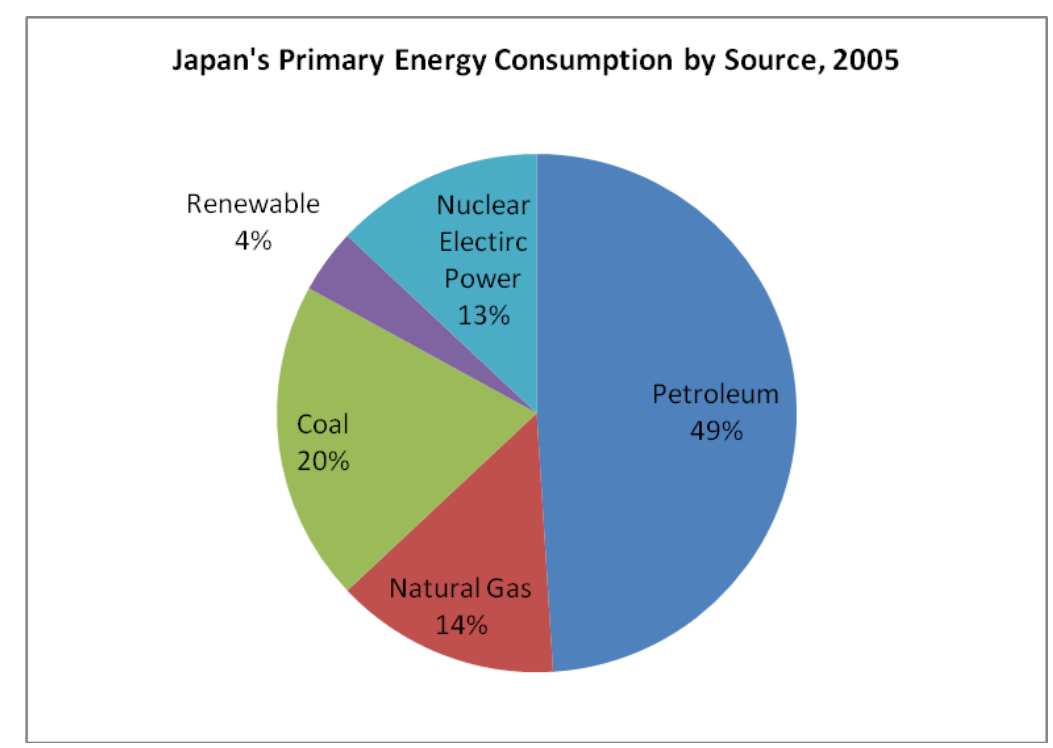

Historically, Japan has been primarily dependent on the Middle East for its oil imports, as roughly 90 percent of Japanese crude oil imports originate in the region, up from 70 percent in the mid-1980s (EIA, 2010a). The country was able to diversify away from the Middle East briefly following the First energy crisis in 1973-74, but this regional dependence returned soon. Japan is currently looking towards Russia, Central Asia, and Africa in order to geographically diversify its oil imports (JSB, 2010).

As the second and third major energy sources, Japan's coal and natural gas situation are quite similar to its oil situation. The country's coal consumption was 185 million metric tons (mmt) in 2007 but its production was zero, meaning all of its coal demands relied on import (EIA, 2010). It is also a large natural gas consumer and

${ }^{11}$ Data Source: EIA. "International Energy Statistics". U.S Energy Infomation Administration. Accessed in August, 2010, http://www.eia.doe.gov. Also see JSB, The Statistical Handbook of Japan 2010 ed. Japan Statistics Bureau \& Statistics Center (Tokyo: Japan Statistics Bureau, 2010). 
relies on imports for all of its natural gas needs. Lacking international pipeline connections, Japan is the largest importer of liquefied natural gas (LNG) in the world. Currently its consumption accounts for about 40 percent of global LNG imports. Due to environmental concerns, the Japanese government has always encouraged natural gas consumption in the country in the last two decades (EIA, 2010).

Japan's staggering external energy dependence makes it extremely sensitive and vulnerable to any supply risks and market volatilities. We will see in the next section that energy supply security has been at the center of Japanese foreign policy since the 1970s.

\subsubsection{The Energy Situation in Western Europe}

During the prolonged period of rapid economic growth that began with reconstruction following WWII and continued until the first energy crisis in 1973, Western Europe emerged as a modern industrial force and a major driving force of world economic growth. The rapid growth in prosperity was at the cost of increasing energy import dependence. Europe's economies, principally coal-based since the industrial revolution, find oil a relatively cheap, plentiful, and highly desirable fuel. 
Between 1950 and 1973, oil consumption in OECD-Europe ${ }^{12}$ grew at an annual rate of 12 percent, to occupy a 60 percent share of total primary energy consumption in 1973, which was in sharp contrast with a mere 12 percent in 1950 (Torrens, 1982).

The most significant factor in Europe's energy situation in the second half of the 1970s was the new oil supply source from the North Sea. Oil production in Europe, almost negligible in the past, increased rapidly as the North Sea discoveries came on stream (Torrens, 1982). Benefiting from the North Sea oil, Britain turned from a major energy importer to energy exporter in the late 1970s. Moreover, from being as much as 97 percent dependent on imports for its oil supply before the arrival of North Sea oil, the OECD-Europe's average external dependence fell to a little over 80 percent in 1980. However, most Western European countries still imported more than 95 percent of their oil throughout the 1980s (Torrens, 1982; EIA, 2010a). The following analysis will focus on the two major energy consumers in Western Europe, Germany (West Germany before 1991) and France.

Germany's oil import dependence was once as much as 44 percent in 1977, and that of France was even more, reaching 74 percent in 1974 (OECD/IEA, 1983). Although since the mid-1970s, oil import dependence in both countries has been declining, imported oil still constitutes a substantial share in the two countries' primary energy demands (OECD/IEA, 1983).

\footnotetext{
${ }^{12} \mathrm{OECD}$, known as the Organisation for Economic Co-operation and is an international economic organisation of 33 countries founded in 1961 to stimulate economic progress and world trade. Here OECD-Europe mainly refers to the European countries that have been OECD members from before the 1990s, namely Austria, Belgium, Denmark, Finland, France, Germany, Greece, Iceland, Ireland, Italy, Luxembourg, Netherlands, Norway, Portugal, Spain, Sweden, Switzerland, Turkey and the United Kingdom.
} 
In 2007, about 59 percent of Germany's total energy consumption depended on energy imports, mainly oil and natural gas (WDI, 2010). Germany was the world's fourth largest oil importer in 2007 , next only to China. Its oil consumption (2.4 million bbl/d) accounted for about 33 percent of primary energy consumption and as high as 94 percent of its oil demands depended on imports (See Figure 6). Similarly, 78 percent of its natural gas consumption comes from imports, making it the world's second largest natural gas importer behind the United States. Although Germany has abundant lignite (brown coal) reserves which has traditionally been used in large quantities to generate electricity, it still needs to import about eight percent of its coal consumption to meet the demand in 2007 (OECD/IEA, 1983; EIA, 2010). 
Figure 6 German Primary Energy Consumption Structure, 2007 ${ }^{13}$

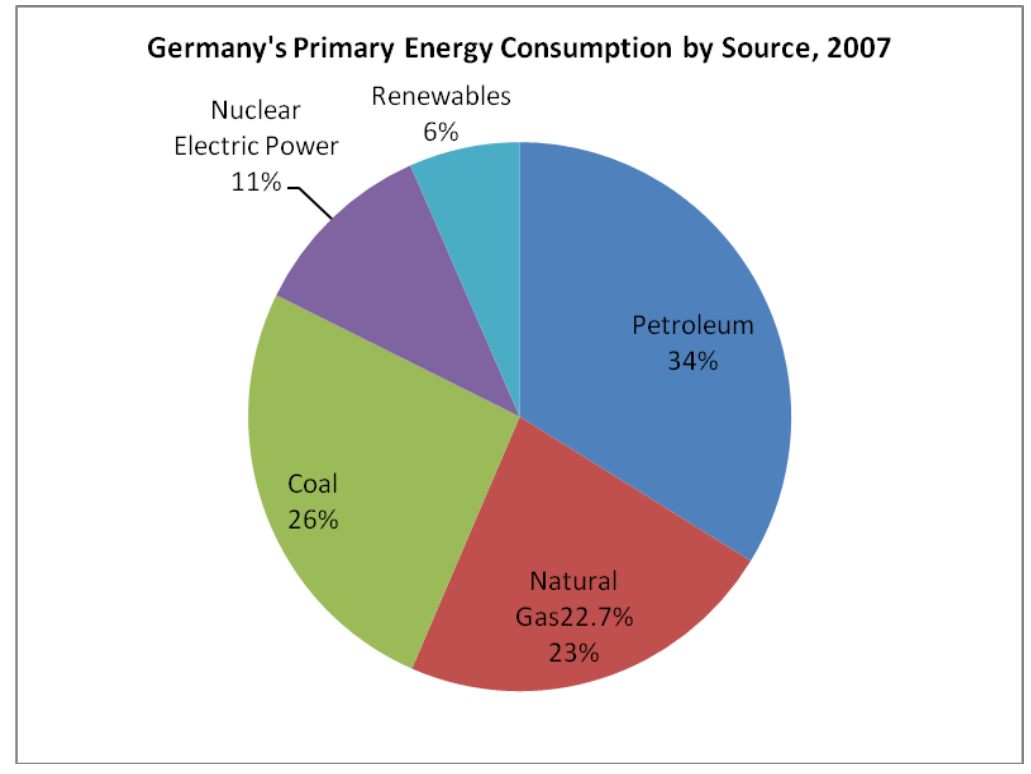

Figure 7 France's Primary Energy Consumption Structure, 2007 ${ }^{14}$

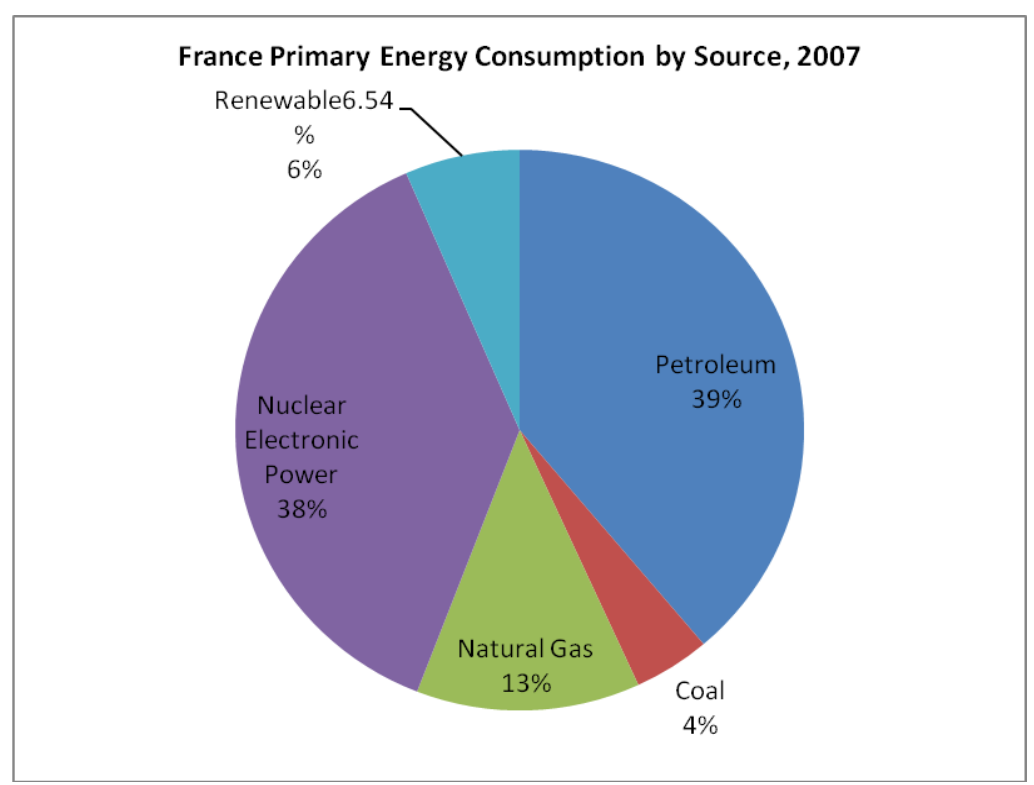

${ }^{13}$ Data Source: OECD/IEA. "Statistics by Country". International Energy Agency. Accessed in August, 2010, http://www.IEA.org/index.asp. ${ }^{14}$ Ibid. 
As for France, imported oil once accounted for over 70 percent of its primary energy consumption in the early 1970s. But today the feature of France's energy situation is the large share of domestically produced nuclear power, which is attributed the success of domestic policy response to reduce the external energy dependence (See Figure 7). The share of nuclear power is almost as high as oil in the end consumption structure, which is also the reason for France's low coal consumption. Nevertheless, virtually all (99 percent) of its oil demand (about 1.9 million bbl/d ) and 97 percent of its natural gas consumption still needs to be imported, which made France's primary energy import dependence close to 50 percent in 2007 (OECD/IEA, 1983; OECD/IEA, 2010; WDI, 2010).

To sum up, there are two features shared by the four major IWCs in their energy situations: the large share of oil (and to a less extent, natural gas) in their energy consumption structures and the high energy import dependence. This situation has not changed much in the last decades. As a result, it has been commonly perceived that the major energy security vulnerability of these countries is the external energy dependence which exposes them to the potential energy supply disruptions and market volatilities. What is even worse, a substantial share of these countries' primary energy consumption is dependent on the Middle East, which has suffered from unstable geopolitical and domestic political situations in the last decades. Therefore, the supply risks originating from this region represent the major threat to these countries' energy security. This is exactly the case of two energy crises in the 1970s. 


\subsubsection{Energy Insecurity: The Threat of Crises}

In October, 1973, an OPEC sub-committee consisting of the oil ministers of the six Gulf member countries (United Arab Emirates, Iran, Iraq, Kuwait, Qatar, and Saudi Arabia) announced that they would unilaterally increase the posted price of Arabian light, the marker crude oil ${ }^{15}$, from USD 3.011 per barrel to USD 5.119 - an increase of 70 percent (Berman, et al., 1982; EIA, 2010a). This price decision was the first phase of what became known in the developed world as the 'energy crisis' or 'oil shock'. Soon after, the five Arab members (not including Iran) of the OPEC committee were joined in Kuwait by the oil ministers of Algeria, Bahrain, Egypt, Libya, and Syria for a meeting. ${ }^{16}$ The ministers were trying to agree on how to use the oil as political weapon to persuade the United States to reconsider its support for Israel and to force the eviction of Israelis from the occupied territories of Palestine (Yergin, 2008: 588).

When the United States re-supplied Israel with weapons after the beginning of the 1973 Arab-Israel "Yom Kippur" War, the OAPEC retaliated by cutting oil production and imposing an oil embargo. The embargo measures included a cut in production by five percent from September's output, and to continue to cut production over time in five percent increments until their economic and political

\footnotetext{
${ }^{15}$ Oil markers are reference points for the various types of oil that are available in the market. Also known as crude oil benchmarks, they were introduced to the world oil market in order to establish a standard for the world's most actively-traded product such as the Arabian light.

${ }^{16}$ Although the meeting included all the members of the Organization of Arab Petroleum Exporting Countries (OAPEC), it was not convened as an OAPEC Council of Ministers, but rather as a Conference of Arab oil Ministers. See Wayne Berman, Richard J. Kessler, and Eugenie Maechling, "The Roots of the Energy Crisis," in The Critical Link: Energy and National Security in the 1980s, ed. Charles K. Ebinger (Cambridge, Massachusetts: Balllinger Publishing Company, 1982).
} 
objectives were met (Yergin, 2008: 589). On October 19, the then-U.S. President Richard Nixon requested Congress to appropriate USD 2.2 billion in emergency aid to Israel. Immediately, Libya announced it would embargo all oil shipments to the United States. Saudi Arabia and the other OPEC states quickly followed suit, joining the embargo targeting the United States, the Netherlands, Portugal, South Africa and Rhodesia (Yergin, 2008: 590). This oil embargo occurred at a time when global demand for oil, especially by the IWCs, was stretching the cartel's production, refining, and transportation facilities to their capacity (Rose, 2004: 434). In an already tight oil market, the cut back of oil production plus embargo further pushed up the spot price ${ }^{17}$ from USD 2.7 in 1973 to USD 10.3 by the end of 1974 (EIA, 2010a).

That a politically inspired embargo triggered an energy crisis heightened the vulnerability of external energy dependence. The IWCs with similar energy situations found they faced ostensibly common threats in the face of oil supply disruptions and, consequently, market volatilities. As one study in the 1970s noted, "Increasing trade in petroleum and higher prices have given rise to complex economic transactions, providing every state with new opportunities for influencing other states, while making each more sensitive to the actions of others" (Choucri and Ferraro, 1976: 53). Energy suppliers had demonstrated their ability to leverage energy for political and economic objectives. The crisis combined in subtle ways with other long-term and cyclical problems, blurring the boundaries between energy and larger macroeconomic predicaments. In complex ways, the energy supply

\footnotetext{
${ }^{17}$ In oil market, "spot" refers to trades of single cargoes of crude oil or petroleum products, while the "contract" market refers to ongoing sales at posted prices.
} 
interruptions and the price increases disrupted both national economic systems and international markets. The disruptions to national economies also underscored a common interest among the IWCs in reducing demand-side pressure on the international energy market (Ikenberry, 1986). ${ }^{18}$

The cut-off of Iranian oil supplies following the collapse of the Shah's regime in the autumn of 1978 unleashed another series of events in the world oil market that are now collectively referred to as the second energy crisis. In contrast to the production cut and embargo of the first energy crisis, this crisis was triggered by domestic political turmoil in one of the key oil suppliers in the Middle East. From December 1978 to March 1979, Iranian oil exports ceased for about 70 days. Almost overnight, 5 million bbl/d of Iranian oil were removed from the international energy market. 3 million bbl/d of surplus oil production was eliminated and world oil reserves were drawn down at the rate of 2 million bbl/d (Berman, et al., 1982: 12). These consequences were of particular concern in Japan and Western Europe, which both depended heavily on supplies of Iranian oil. ${ }^{19}$

However, much more serious were perceptions of future oil scarcity among major importing countries, which led to panic purchases on the spot market in order to increase oil stocks. Thus the oil prices soared. Producers abrogated existing

\footnotetext{
${ }^{18}$ This common interest results in the decision to establish International Energy Agency (IEA) on the Washington Conference in 1974. IEA is a Paris-based intergovernmental organization established in the framework of the Organization for Economic Co-operation and Development (OECD). It was initially dedicated to responding to physical disruptions in the supply of oil, as well as serving as an information source on statistics about the international oil market and other energy sectors.

${ }^{19}$ In 1978, Iranian oil accounted for about 10 percent of United States crude oil imports. Corresponding figures for other major oil importers were: Japan, 16 percent; Germany, 12 percent; the United Kingdom, 15 percent; France, 9 percent. See Berman, Kessler, and Maechling, "The Roots of the Energy Crisis.", p12.
} 
contracts, delivering more oil into the higher priced spot market. Escalating spotmarket prices beginning in early 1979 then drove up OPEC oil prices in successive increments. Thus the oil price became the most urgent threat to oil importers. The official price of the Arab marker rose from USD 12.7 in December 1978 to USD 22.8 in December 1979, an increase of almost 90 percent. Other OPEC members' crude oil prices varied above that level, and spot prices soared above USD 38.1 a barrel by the end of 1979 (Hubbard, 1986; EIA, 2010a). In September 1980, Saudi Arabia further raised the contract price of its marker oil to USD 32 a barrel. This effectively raised the oil bill of the oil-importing countries by USD 900 million retroactively and USD 7 billion annually, causing their balance-of-payment deficit to peak at USD 109 billion in 1980 (Rourke, 1993: 504).

Meanwhile, by the end of 1979, hostilities between Iran and Iraq had erupted. Oil production in Iran nearly stopped entirely, and Iraq's oil production was severely curtailed as well, removing about 4 million bbl/d or 10 percent of crude oil production from the international market. The uncertainty and insecurity generated by Iran-Iraq War sent spot prices as high as USD 38.6 by the end of 1980 . The rapid rise in oil prices from 1978 to 1980 again placed a heavy burden on the IWCs, generating macroeconomic problems such as inflation, unemployment, unbalanced payment and low economic growth rates (Torrens, 1982; Berman, et al., 1982: 32). 


\subsubsection{The Nature of Western Energy Security Issues}

While the cost of the energy crises of the 1970s varied from country to country and have been widely debated, there is no doubt that the impact of the energy crises was severe, causing years of economic dislocation and stagnation. In the early 1980s, the costs of the energy crises were estimated at USD 1.2 trillion in lost economic growth for the seven largest industrial countries in the world (Jaffe and Soligo, 2008: 47). In the aftermath of the energy crises, the growth rate for the industrial world came to a halt, after witnessing a strong period of five percent per annum expansion in the 1960s (Stobaugh and Yergin, 1980; Jaffe and Soligo, 2008: 47).

Additionally, a large body of literature based on the empirical evidence of the energy crises since the mid-1970s has suggested the consequences of serious oil supply disruptions and price volatilities (Rasche and Tatom, 1981; Hamilton, 1983; Burbidge and Harrison, 1984; Hamilton, 1985; Santini, 1985; Gisser and Goodwin, 1986; Loungani, 1986; Tatom, 1988; Mork, 1989; Hamilton and Herrera, 2004; Aguiar-Conraria and Wen, 2007). For instance, James Hamilton first published an influential article in 1983, demonstrating that an oil price increase had preceded all but one recession (that in 1960) in the United States since the end of the Second World War (Hamilton, 1983). ${ }^{20}$ This finding has the effect of diffusing the spotlight on the 1973 and 1979-80 energy crises and expanding researchers' attention to the entire post-war period. Micha Gisser and Thomas Goodwin reinforced Hamilton's

\footnotetext{
20 "Proceeded" here refers to granger-proceeded. The Granger causality test is a statistical hypothesis test for determining whether one time series is useful in forecasting another. See C W J Granger, "Investigating Causal Relations by Econometric Models and Cross-Spectral Methods," Econometrica 37, no. 3 (1969). Hamilton successfully established Granger causality relations between the two variables of economic recession and increasing oil price.
} 
findings for the United States in 1986 (Gisser and Goodwin, 1986). John Burbidge and Alan Harrison found mixed but overall reinforcing evidence from Britain and Japan as well as the United States (Burbidge and Harrison, 1984).

In general, the empirical research has convincingly argued that such energy supply disruption is a determinant factor of economic activity by bringing large negative impacts and leads to recessions, lower GDP growth and inflation. Therefore, the energy supply risks such as energy crisis could result in serious deprivation of economic welfare and consequently affect the energy dependent countries' comprehensive competitiveness. Thus, based on the analysis in this section, the linkage between energy and national security in the IWCs can be explained by a model (See Figure 8). 
Figure 8 Model of Energy Security in IWCs ${ }^{21}$

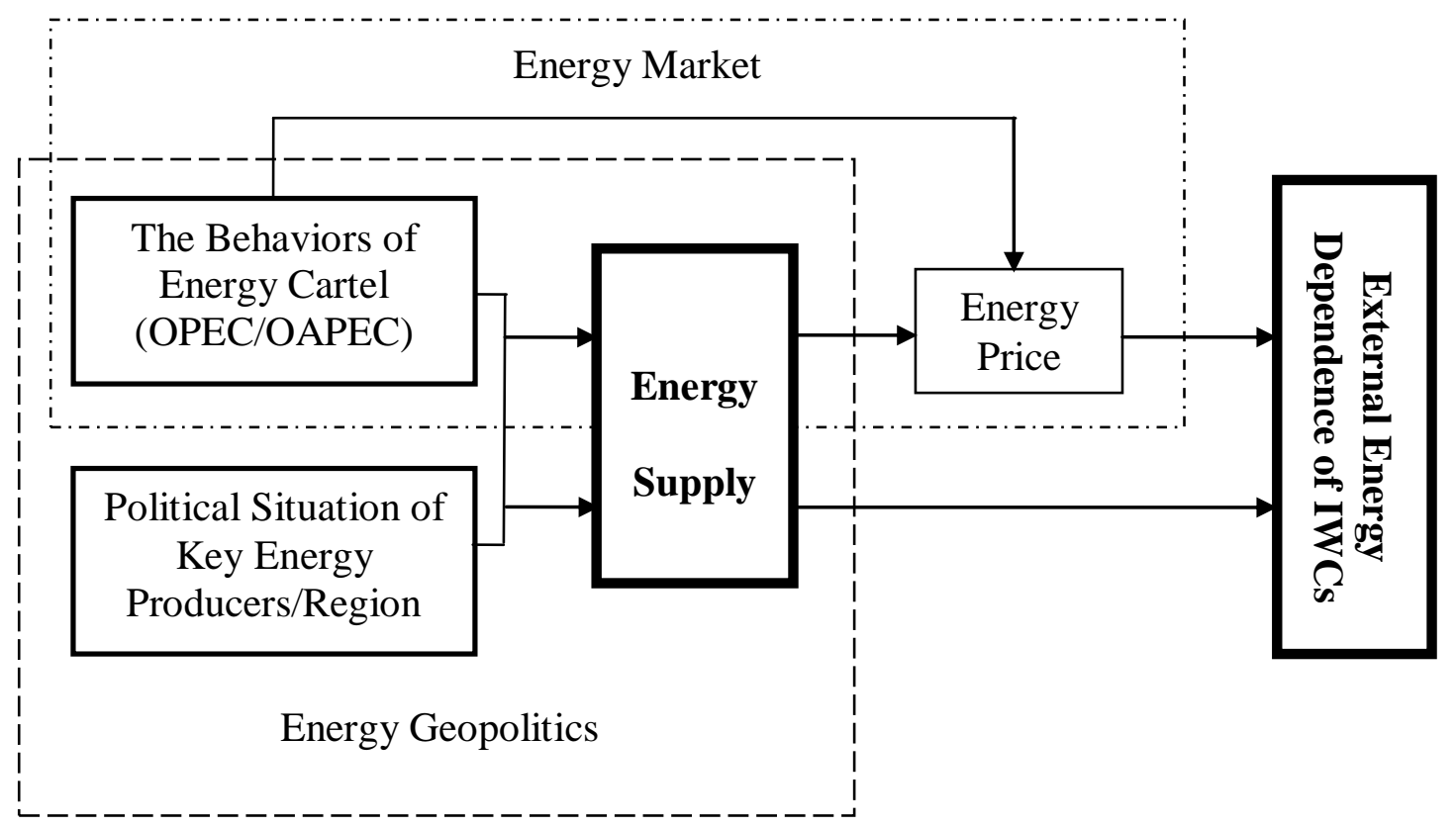

Threat

Vulnerability

As shown in the model, two factors are crucial to energy security in energy dependent countries. The geopolitical situation in key energy producing regions (mainly the Middle East), and the behavior of energy producers as well as the domestic political situation of key oil producers could significantly affect the energy supply. Fluctuations of energy output and disruptions of energy supply can directly restrain the energy production and thus affect the availability of energy resources for importers. In regard to the world energy market, from the early 1970s to mid-1980s, through the official price system of OPEC, the oil cartel also controlled the contract price for long term energy supply.

\footnotetext{
${ }^{21}$ The model is developed by the author.
} 
In sum, it is the vulnerability of external import dependence and threat of supply risks that constitutes the material basis and historic context of their energy security thinking. When heavy dependence and supply threats exist simultaneously, the supply disruptions and increasing energy prices are likely to jeopardize the economic performance of the energy importers. The nature of IWCs' energy insecurity is therefore in essence an external supply issue, which requires outwardlooking policy responses. 


\subsection{A Traditional Energy Security Approach}

Based on the vulnerability they have and the threats they face, the mainstream energy security thinking in the West over the last three decades has been characterized by an overwhelmingly oil-oriented and external supply-sided energy security approach, which is concluded by Erica Downs and several other scholars as "the traditional thinking on energy security" (Fried and Trezise, 1993: 1; Stares, 2000: 22; Downs, 2004: 23). This approach, characterized by a traditional energy security concept and the strategic-foreign policy solution, has been the mainstream in both academic discussions and policy making in the major IWCs.

\subsubsection{Conceptualization of Energy Security}

Since the 1970s, energy security concerns became a policy priority for most of the IWCs, which also stimulated the conceptualizations of energy security in academia. The energy security literature in the West, in particular in the United States, is marked by a focus on the security of energy supply. Defined by Daniel Yergin, the most influential concept of energy security involves: “....assuring adequate, reliable supplies of energy at reasonable prices and in ways that do not jeopardize major national values and objectives" (Yergin, 1988: 111).

Similar concepts emphasizing the energy supply and price have been influencing energy security studies in the West over the last decades. David Deese defined energy security as "a condition in which a nation perceives a high probability that it 
will have an adequate energy supplies at affordable prices" (Deese, 1980: 140). In the 1990s, Douglas R. Bohi contended that energy insecurity was "the loss of economic welfare that may occur as a result of a change in the price or availability of energy" (Bohi, et al., 1996: 1). Even more recently, the mainstream energy security literature still maintains this line of energy security concept. For example, Jonathan Stern and J. Bielecki who suggest that the concept is centered on notions of supply "reliability" and "adequacy" at "reasonable" market-determined prices (Bielecki, 2002: 237).

On the other hand, energy security defined by the International Energy Agency (IEA) represents most of the OECD governments' perception of energy security. In 1985, the IEA defined energy security as an "adequate supply of energy at a reasonable cost"'(OECD/IEA, 1985: 29) and later posited that "energy security is simply another way of avoiding market distortions" (OECD/IEA, 1995: 23) because "smoothly functioning international energy markets" will deliver "a secure adequate, affordable and reliable - supply of energy' (OECD/IEA, 2002: 3). This IEA definition of energy security has been consistently restated and most recently expressed as "energy security always consists of both a physical unavailability component and a price component..." (OECD/IEA, 2007: 32).

This approach to conceptualize energy security constitutes the core and basis of the mainstream energy security thinking in the West, which have also directed the policy responses in the last decades. 


\subsubsection{Strategic-Foreign Policy Responses to Energy Insecurity}

In the aftermath of the two crises in the 1970s, the major IWCs developed different policies to cope with their energy insecurity. The inward-looking policies like increasing the domestic energy production and raising the share of nuclear power have to some extent alleviated their energy vulnerabilities. For example, the United States began the "Project Independence" after the first energy crisis, which was designed to end the need for U.S. energy imports by 1980. Utilities which had previously been moved away from coal for environmental reasons were asked to resume coal burning. In 1975, President Gerald Ford proposed a 10-year plan to build 200 nuclear power stations, add 150 coal-fired power stations and 20 major synthetic oil plants to sharply reduce energy dependence. In the end, not much of either plan materialized. Instead, the most substantial contributions were decisions by the U.S. Congress to endorse construction of an oil pipeline from Alaska and fuel efficiency standards for U.S. automobiles (Bahgat, 2001; Jaffe and Soligo, 2008: 48).

Nevertheless, oil consumption had been built into their development model and the vulnerability of dependence in these countries is almost unshakable. Gradually, these countries found they must mainly focus on the outward-looking policies to pin down the external threats. As one of the superpowers in the Cold War and the "lonely superpower" (Huntington, 1999) in the post-Cold War era, strategic and foreign policy thinking of energy security has become the mainstream energy security discourse in the U.S. and influenced the policy response (Deese, 1980; Painter, 
1991; Klare, 2001; Stern, 2006). While in Japan and Western Europe energy foreign policy, in particular energy diplomacy, has played a vital role in response to energy insecurity (Lieber, 1980; Yorke, 1981; Correljé and Linde, 2006).

\section{i. The Continuing Salience of the Carter Doctrine}

By the early 1980s, abandoning the hope of energy independence, the U.S. shifted emphasis to developing a military deterrent capability to protect the energy supply from the Middle East. This policy shift came to be known as the Carter Doctrine.

In a Cold War background, the energy security threats did not only mean the supply risks to the United States. By that time, the Soviet Union had achieved a massive military build-up which brought it to the strategic parity with the U.S.. Washington felt that both the ability and the disposition of the United States to take a strong position in defending its energy interests in the Middle East and elsewhere were measurably reduced. Plus the relations with OAPEC members became increasingly strained by U.S. support for Israel, and the relations with Iran sank to an all-time low after the fall of the Shah and subsequent hostage crisis (Painter, 1991: 194).

What worried the U.S. most besides the Iran-Iraq War in the early 1980s was the Soviet invasion of Afghanistan in December 1979. That meant the Soviet Union could deploy its armed force within five hundred miles from the key oil fields in the Middle East. In response, in January 1980, the then-President Jimmy Carter announced in his State of the Union address that access to the Persian Gulf's oil resources was essential to the health of the U.S. economy. Carter declared, the Gulf 
region "contains more than two-thirds of the world's exportable oil", and so must not be allowed to fall under the control of hostile forces. He stressed,

let our position be absolutely clear: an attempt by any outside force to gain control of the Persian Gulf region will be regarded as an assault on the vital interests of the United States of America, and such an assault will be repelled by any means necessary, including military force.

(Carter, 1980)

This avowal was directed, in the first instance, toward the Soviet Union, but was also interpreted as applying to any hostile nation, such as the Islamic Republic of Iran (Klare, 2006: 34). This declaration later became the so-called Carter Doctrine.

To implement the doctrine, the United States moved a substantial number of ships from the Sixth and Seventh Fleets into the Gulf region and established the rapid deployment joint task force (RDJTF) and deployed a permanent US naval presence in the Gulf. While they may have employed different rhetoric words, all the presidents who succeeded Carter have reaffirmed the basic premises of this 1980 doctrine and have taken steps to enhance America's capacity to project military force into the greater Persian Gulf region. For instance, in 1982, the list of US national strategic priorities, approved by then-President Reagan, put as the second priority (after defending Western Europe) for general strategic planning (in case of conflict with the Soviet Union), "to guarantee access to the oil in Southwest Asia", and to "defend the Gulf's oil" (Wionczek, 1983: 840). 
In the early 1990s, two events significantly affected the energy security situation of the West. The first was the collapse of the Soviet Union and the end of the Cold War; the second was Iraq's invasion of Kuwait. As the end of the Cold War, many formative expressions of America's Cold War Policy - the Truman Doctrine, the Eisenhower Doctrine, and the Nixon Doctrine, among others - have been rendered moot by the collapse of the Soviet Union. The Carter Doctrine, however, continues to govern US foreign policy in post-Cold War era till today (Klare, 2006). The fade away of Soviet threats to Middle East doesn't mean the disappearance of geopolitical threats to Western energy security, to the contrary, the variations of Carter Doctrine are repeatedly practiced by the United States and its allies to eliminate the geopolitical threats since the early 1990s.

During 1990-91, the disruption of Kuwaiti and Iraqi oil from world oil markets due to the first Gulf War was managed, but with a costly volatility in world energy market. The temporary rise of prices proved costly in terms of inflation and is believed to have brought American economy into another recession (Barry, 1992). Even with the supply and demand effects largely under control, initial uncertainties and market psychology caused oil prices to triple (Lieber, 1992). For the United States, Iraq's invasion of Kuwait in 1990 and the subsequent war led by the U.S. against Iraq was in fact the post-Cold War practice of the Carter Doctrine, which is also viewed as the policy of 'preemption'. It means after the end of Soviet threat to the Middle East, any Gulf superpower must be preempted in order to guarantee the stable and affordable flow of oil from that region to the West (Wolfowitz, 1992). 
Iraq thus became the first power that U.S. needed to preempt by two wars in twelve years. Iran may possibly be the next policy object to be preempted (Stern, 2006).

Shortly after taking office in 2001, George W. Bush established the National Energy Policy Development Group (NEPDG) to examine the 'energy crisis' the United States faced. The Group concluded in its report that that for the foreseeable future oil would continue to play a significant role in the energy mix and the Persian Gulf will retain its strategic importance for U.S. energy security (Bahgat, 2001). The US invasion of Iraq in 2003 can be viewed as a natural extension of the Carter Doctrine, along with other U.S. military moves in the Persian Gulf area since the Gulf War. However, the logic of the Carter Doctrine is no longer being applied to the Gulf alone.

The political instability in the Middle East has convinced the United States and other major oil consuming countries to search for oil resources in other regions. Thus since the mid-1970s exploration and development operations have accelerated all over the world including the North Africa, Caspian Basin and Latin America (Klare, 2006: 32). Increasingly, access to oil in other producing areas is also being viewed in Washington as a vital interest, and thus as something that must be protected by military force whenever necessary. For example, in the late 1990s, when President Clinton determined that the Caspian Sea basin, which was largely under the control of the Soviet Union until 1992, should become a major source of oil for the United States and its allies, thereby helping to lessen U.S. dependence on the Gulf area. As Michael Klare points out, what could be called the "globalization" of the Carter 
Doctrine (Klare, 2006: 32) may prove to be one of the most significant developments of American foreign policy in the post-Cold War era.

The Carter Doctrine demonstrates that, largely due to the supply security concern, the problem of access to Middle East energy resources figured very high on the American alliance's policy agenda. A strategic-oriented energy security thinking has thus been dominant in the U.S..

\section{ii. Energy Foreign Policy in Japan and Western Europe}

Very simply put, Japan is most concerned with safeguarding its independence and prosperity after WWII (Mendl, 1980: 611). The whole edifice of Japan's economic interests was built in an era when the United States was undeniably the world's dominant economic and military power and when energy and other raw materials were relatively cheap on the world markets. Anxieties about Japan's ability to sustain its economic prosperity, which is so dependent on external factors, are always the biggest vulnerability for its economic security and comprehensive national security (Mendl, 1980).

Access to essential sources of energy and raw materials and to the markets for Japanese exports does not only require stable supply, but also safe passage over the oceans and good relations with the countries concerned. However, for Japan the 1970s was a decade of panics and has raised doubts about its basic post-war policy of economic growth and passive diplomacy under the protection of American military power (Mendl, 1980). Prior to the first energy crisis Japan imported 
approximately 40 percent of its oil needs (which was almost 30 percent of its primary energy demand) from the OAPEC countries (EIA, 2010a). Therefore, when OAPEC cut its oil production by 25 percent in November 1973 and classified Japan as an 'unfriendly' country, Tokyo was thrown into a state of panic (Yorke, 1981: 434). In order to restore interrupted supplies, Japan proceeded to abandon the principle on which its post-WWII external relations had been based - the separation of economic and political matters. Japan had come to realize that because of its heavy dependence on OAPEC energy producers, political relations with these countries must not be ignored; and Japan could no longer rely upon the United States on account of its links with Israel to protect Japanese energy interests (Yorke, 1981).

If the first energy crisis elicited a tactical diplomacy response by Japanese government, which was Tokyo's adoption of a 'pro-Arab' position in order to gain the status of 'friendly country ${ }^{22}$, the strike of the second energy crisis led to a profound policy reassessment in Japanese government. It was largely energy security concerns that forced the Japanese government to re-examine the foundation of its post-WWII diplomatic and security policies (Calabrese, 2002: 84). Immediately after the second energy crisis, a commission known as the Comprehensive National Security Study Group was appointed by the then-Japanese Prime Minister Masayoshi Ohira. The commission issued its final report in July 1980. In the report, security is defined as "protecting the people's life from various forms of threat" (Inoguchi, 1993: 36). As a Japanese scholar notes, "The path....to

\footnotetext{
${ }^{22}$ This 'friendly country' status enabled Japan to win the OAPEC's cancellation of a 5 percent production cutback and a 10 percent increase instead. See John Calabrese, "In the Shadow of Uncertainty: Japan's Energy Security and Foreign Policy," Pacific and Asian Journal of Energy 12, no. 1 (2002). p84.
} 
comprehensive security was not linear. Rather, it involved a zigzag course reflecting the solid pacifist-isolationist sentiments of the public" and required "the government to overhaul its whole range of public policies in order to redirect its foreign policy" (Inoguchi, 1993: 36).

Following this policy guideline, Japan's main instrument in the pursuit of security has been the so-called 'economic diplomacy' or 'resources diplomacy', whose function is to combine the protection of the nation's economic prosperity with the exercise of influence abroad, and to satisfy the need to be seen as a major power without provoking potential enemies (Mendl, 1980; Yorke, 1981). Thus, energy security has since become a key issue to direct Japan's foreign policy. For example, Japan has made huge efforts to build 'multilayered relations' with the Gulf countries rests on three pillars - politics, economics, and 'new areas' of cooperation. This framework is based on principles enumerated in documents such as Japan-Saudi Arabia Comprehensive Partnership toward the $21^{\text {st }}$ Century, and Japan-GCC ${ }^{23}$ Cooperation towards the $21^{\text {st }}$ Century (Calabrese, 2002: 88). Given the persistence of Japan's energy dependence on foreign supplies, to achieve energy security by foreign policy will continue to be a major preoccupation of Japanese officials for years to come. Japan's pursuit of energy security will, therefore, shape, as well as be shaped by, how Tokyo defines and conducts its foreign relations.

${ }^{23}$ GCC, the Gulf Cooperation Council, also known as the Cooperation Council for the Arab States of the Gulf (CCASG), is a political and economic union involving six Arab states: Bahrain, Kuwait, Oman, Qatar, Saudi Arabia and the United Arab Emirates. 
Like Japan, the major Western European energy consumers responded to the vulnerability of dependence and the threats of supply risks by bilateral as well as multilateral solutions. Germany, for example, struck a natural gas pipeline deal with the Soviet Union despite the tensions this decision would create in US-German relations. France pursued an ambitious nuclear power expansion programme and imposed substantial taxes on gasoline consumption. France also joined Germany in purchasing natural gas from the Soviet Union (Jaffe and Soligo, 2008: 48).

Moreover, French foreign policy response included a pro-Arab policy in regard to the Middle East conflict and efforts to establish special bilateral relationships with individual oil producing states such as selling advanced weapons systems to Iraq (including nuclear equipment). France tried the forceful promotion of a EuropeanArab dialogue, took a pro-Arab stance in deliberations on the Arab-Israeli conflict throughout the 1980s and even blocked a favorable European Economic Community (EEC) response to the Egypt-Israel Camp David Accords (Lieber, 1980; Jaffe and Soligo, 2008: 48).

More recently, as the natural gas dependence on Russia has been increasing (Cohen, 2007), particularly in light of Russia's cut-off of gas supplies to the Ukraine in 2006 and again in 2009 (Jaffe and Soligo, 2008; RFE, 2009), as well as threats of oil supply cut-offs by Iran during the geopolitical standoff over its nuclear program, energy foreign policy is taking on a greater policy salience in Europe. The incidents between Russia and Ukraine remind the European analysts of the consequences of energy resources being used as political leverage to gain political ends as in the 
1970s' energy crises (Correljé and Linde, 2006). Therefore, the high oil dependence on the Middle East and the increasing natural gas dependence on Russia will continue to be viewed as the main vulnerability of Western Europe energy security.

\section{Summary}

Evidently, the single most important feature in the IWCs' energy-economy situations is that imported oil is a key factor determining their economic performance and overall competitiveness. As a result, external energy dependence makes them vulnerable to supply risks such as energy supply disruptions and market volatilities, especially when a substantial share of their primary energy demand is from a politically unstable energy producing region, such as the Middle East. These supply risks create a major source of energy insecurity as shown repeatedly over the 20th century, bringing large negative impacts to the IWCs' economies. Therefore, their energy security thinking has been built around the security of external energy supply. A traditional energy security approach characterized by external supply sided and oil-oriented energy security concept and subsequent strategic-foreign policy responses has been thus established to address their energy security issues. 


\section{Chapter 4 Energy Security in China - Energy Situation and Energy Security Approach}

\section{Introduction}

Since the mid-1990s, one of the most important changes in the world energy situation is that China has moved from being a minor and self-sufficient energy consumer to become the world's fastest-growing energy consumer. Soaring energy demand is both a consequence and a driver of the remarkable growth in the country's economy. As China's economic performance increasingly depends on energy supply, especially on fossil fuels, energy has therefore become a major national security concern for both Chinese academia and its political leadership.

In this chapter, I argue that, although oil only plays a modest role in the comprehensive picture of China's energy situation, an oil-oriented and external supply-sided traditional energy security approach dominates China's energy security thinking. In other words, instead of carefully examining the unique energy vulnerabilities and the threats China faces in an energy situation which is profoundly different to that of the IWCs, Chinese energy security thinking has been largely shaped by 'self-reliance' doctrine and Western thinking.

Based on detailed data and statistics, a survey of the energy situation and energy security thinking from Chinese scholarly research, government documents and 
official media is provided to help us understand Chinese authorities' perception and policies on its energy security. The scholarly discourse in China's leading academic publications in recent years is important because a vast majority of the articles were funded by the Chinese authorities which decide the priority of the energy security policy.

\subsection{A Comprehensive Picture of China's Energy Situation}

As economic growth has exploded since the late 1970s, both China's primary energy production and consumption have increased significantly. As widely known, in terms of aggregate energy, China is the second largest energy consumer, but what is less known is that China is the world's largest energy producer and maintains an energy self-sufficiency rate over 90 percent (People's Daily, Sep 27, 2009; WDI, 2010). ${ }^{24}$ Table 1, Figure 9 and Figure 10 show China's energy production and consumption by primary energy sources over time.

In terms of China's domestic energy production, there appear to be three distinct periods during the last two and half decades (See Table 1 and Figure 9). During the decade 1985-1995, with the rapid growth of the economy, the growth rate of energy production was approximately 4 percent per annum. But the energy supply was in shortage, which hampered the growth of the national economy. This was followed during the period $1995-2000$ by a period of stagnation and decline. With the

\footnotetext{
${ }^{24}$ According to the World Bank, China maintained an energy self-sufficiency rate of 93 percent in 2007. See WDI, "World Development Indicators: Energy Net Imports as Percentage of Energy Use " (The World Bank, 2010).
} 
slowdown in economy growth, the total energy consumption trended downward. However, 2001 was the turning point year when energy consumption increased rapidly, and a gap between supply and demand has persisted since then. Energy production has soared at an annual growth rate of nine percent driven by the economic recovery and rapid GDP growth. Despite the ups and downs, the composition of China's primary energy production has changed little over time. Coal continued to dominate primary energy production with a share of over 76 percent in 2008. The share of oil production has obviously declined over time and this trend has accelerated since 2000. Natural gas and other primary energy production have increased, although with fluctuations. Other primary energy production shares increased at an average of approximately three percent annually (Yuan, et al., 2007: 1181; NBS, 2009; Ma, 2009: 81).

A similar scenario can be found in primary energy consumption and its composition (See Table 1 and Figure 10). The only difference is that, with a higher growth rate for consumption, the role of coal as major energy source declined slightly from over 75 percent in the 1980s and 1990s to about 68.7 percent in 2006 (See Table 1). Despite the economic slowdown in exports and domestic demand since 2008, China's demand for energy remains high. The total primary energy consumption has also increased rapidly, and amounted to 2850.0 million tons of coal equivalent (Mtce) in 2008, second only to that of the United States (NBS, 2009). 
Table 1 China's Energy Production and Consumption Over Time ${ }^{25}$

\begin{tabular}{|c|c|c|c|c|c|}
\hline Year & Aggregate & \multicolumn{4}{|c|}{ Share (percent) } \\
\hline \multicolumn{2}{|c|}{ Production (Mtce) } & Coal & Oil & Natural Gas & Others \\
\hline 1985 & 855.5 & 72.8 & 20.9 & 2.0 & 4.3 \\
\hline 1990 & 1039.2 & 74.2 & 19.0 & 2.0 & 4.8 \\
\hline 1995 & 1290.3 & 75.3 & 16.6 & 1.9 & 6.2 \\
\hline 2000 & 1289.8 & 72.0 & 18.1 & 2.8 & 7.2 \\
\hline 2005 & 2058.8 & 76.5 & 12.6 & 3.2 & 7.7 \\
\hline 2006 & 2210.6 & 76.7 & 11.9 & 3.5 & 7.9 \\
\hline 2007 & 2354.2 & 76.6 & 11.3 & 3.9 & 8.2 \\
\hline 2008 & 2600.0 & 76.7 & 10.4 & 3.9 & 9.0 \\
\hline \multicolumn{6}{|c|}{ Growth rate annually ( Percent) } \\
\hline 1985-1990 & 4.0 & 0.4 & -1.9 & 0.0 & 2.2 \\
\hline 1990-1995 & 4.4 & 0.3 & -2.7 & -1.0 & 5.3 \\
\hline $1995-2000$ & 0.0 & -0.9 & 1.7 & 8.1 & 3.0 \\
\hline $2000-2005$ & 9.8 & 1.2 & -7.0 & 2.7 & 1.4 \\
\hline $2005-2006$ & 7.4 & 0.3 & -5.6 & 9.4 & 2.6 \\
\hline $2006-2007$ & 6.5 & -0.1 & -5.0 & 11.4 & 3.8 \\
\hline $2007-2008$ & 10.4 & 0.1 & -8.0 & 0 & 9.8 \\
\hline \multicolumn{6}{|c|}{ Consumption (Mtce) } \\
\hline 1985 & 766.8 & 75.8 & 17.1 & 2.2 & 4.9 \\
\hline 1990 & 987.0 & 76.2 & 16.6 & 2.1 & $\overline{5.1}$ \\
\hline 1995 & 1311.8 & 74.6 & 17.5 & 1.8 & 6.1 \\
\hline 2000 & 1385.5 & 67.8 & 23.2 & 2.4 & 6.7 \\
\hline 2005 & 2246.8 & 69.1 & 21.0 & 2.8 & 7.1 \\
\hline 2006 & 2462.7 & 69.4 & 20.4 & 3.0 & 7.2 \\
\hline 2007 & 2655.8 & 69.5 & 19.7 & 3.5 & 7.3 \\
\hline 2008 & 2850.0 & 68.7 & 18.7 & 3.8 & 8.9 \\
\hline \multicolumn{6}{|c|}{ Growth rate annually ( Percent) } \\
\hline $1985-1990$ & 5.2 & 0.1 & -0.6 & -0.9 & 0.8 \\
\hline $1990-1995$ & 5.9 & -0.4 & 1.1 & -3.0 & 3.6 \\
\hline $1995-2000$ & 1.1 & -1.9 & 5.8 & 5.9 & 1.9 \\
\hline $2000-2005$ & 10.2 & 0.4 & -2.0 & 3.1 & 1.2 \\
\hline $2005-2006$ & 9.6 & 0.4 & -2.9 & 7.1 & 1.4 \\
\hline $2006-2007$ & $\overline{7.8}$ & 0.1 & -3.6 & 16.7 & 1.4 \\
\hline $2007-2008$ & 7.3 & 0.1 & -5.1 & 8.6 & 21.9 \\
\hline
\end{tabular}

${ }^{25}$ Data Source: NBS, China Statistical Year Book 2009 (中国统计年鉴 2009), ed. National Bureau of Statistics of China (中国国家统计局编) (Beijing: China Statistics Publishing House (中国统计出 版社), 2009). 
Figure 9 China Primary Energy Production, 1978-2008 ${ }^{26}$

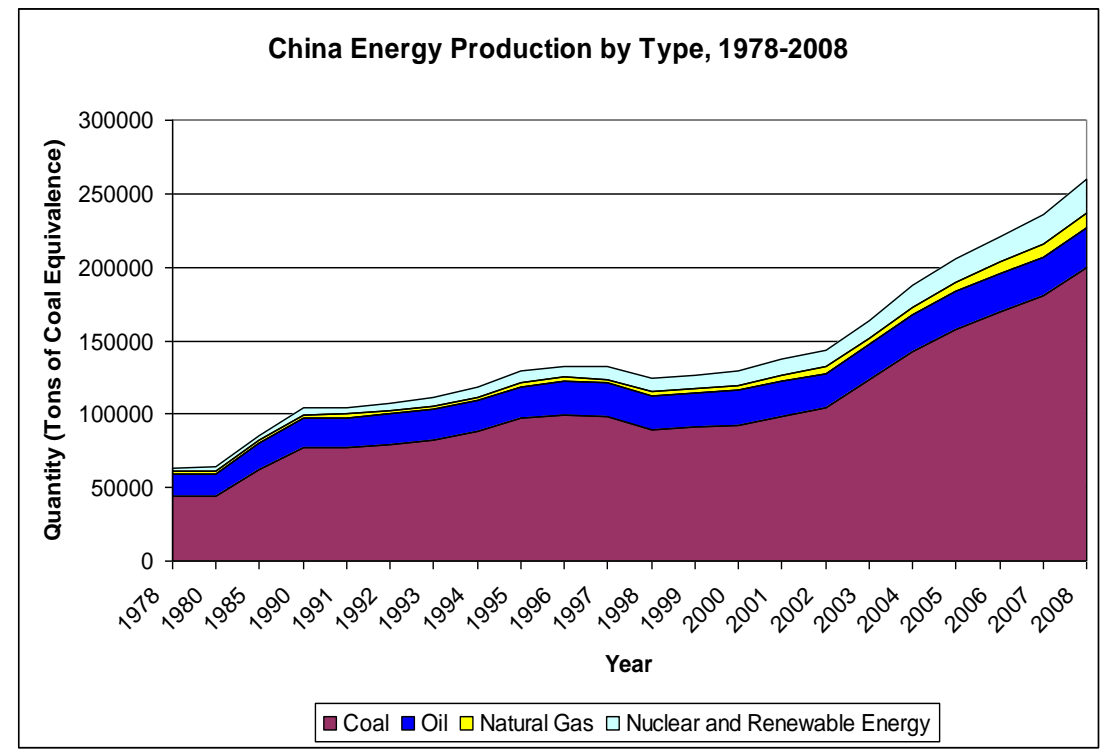

Figure 10 China Primary Consumption, 1978-2008 ${ }^{27}$

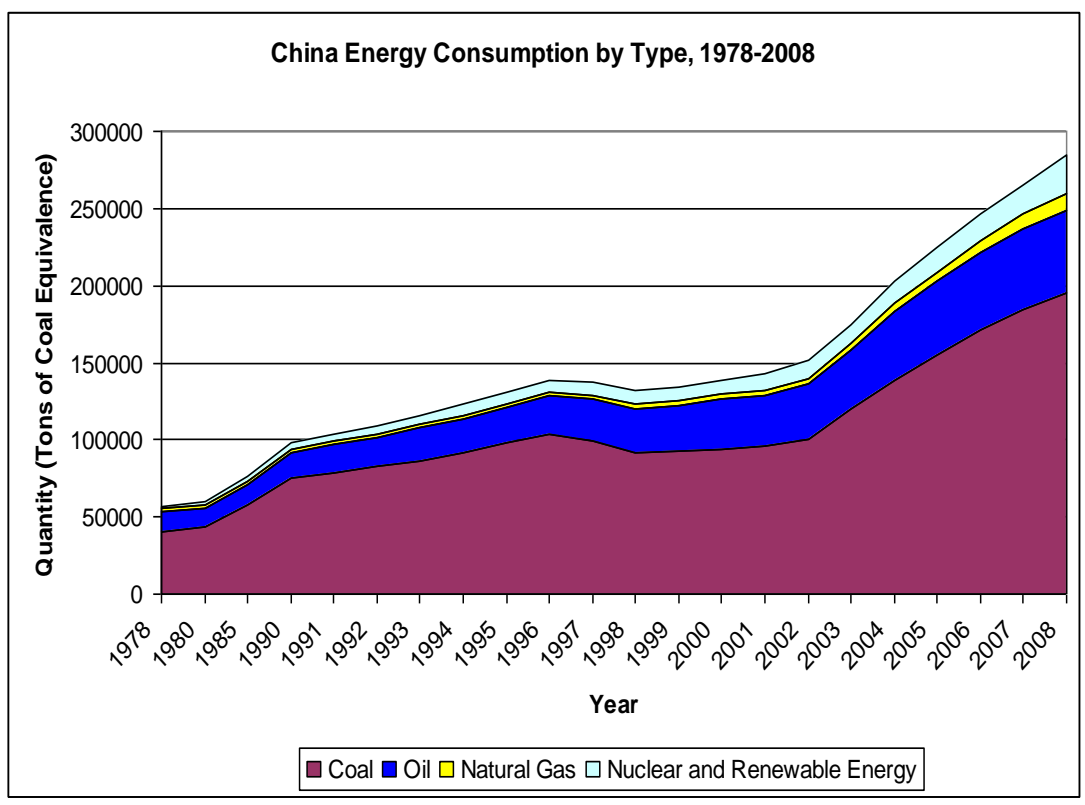

${ }^{26}$ NBS, "6-1 Total Production of Energy and Its Composition (表 6-1 能源生产总量及构成)," in China Statistical Year Book 2009 ( 中国统计年鉴2009), ed. National Bureau of Statistics of China (Beijing: China Statistics Publishing House, 2009a).

${ }^{27}$ NBS, "6-2 Total Consumption of Energy and Its Composition (表 6-2 能源消费总量及构成)," in China Statistical Year Book 2009 (中国统计年鉴2009), ed. National Bureau of Statistics of China (Beijing: China Statistics Publishing House, 2009b). 
Figure 11 China's Primary Consumption Structure, $\mathbf{2 0 0 8}^{28}$

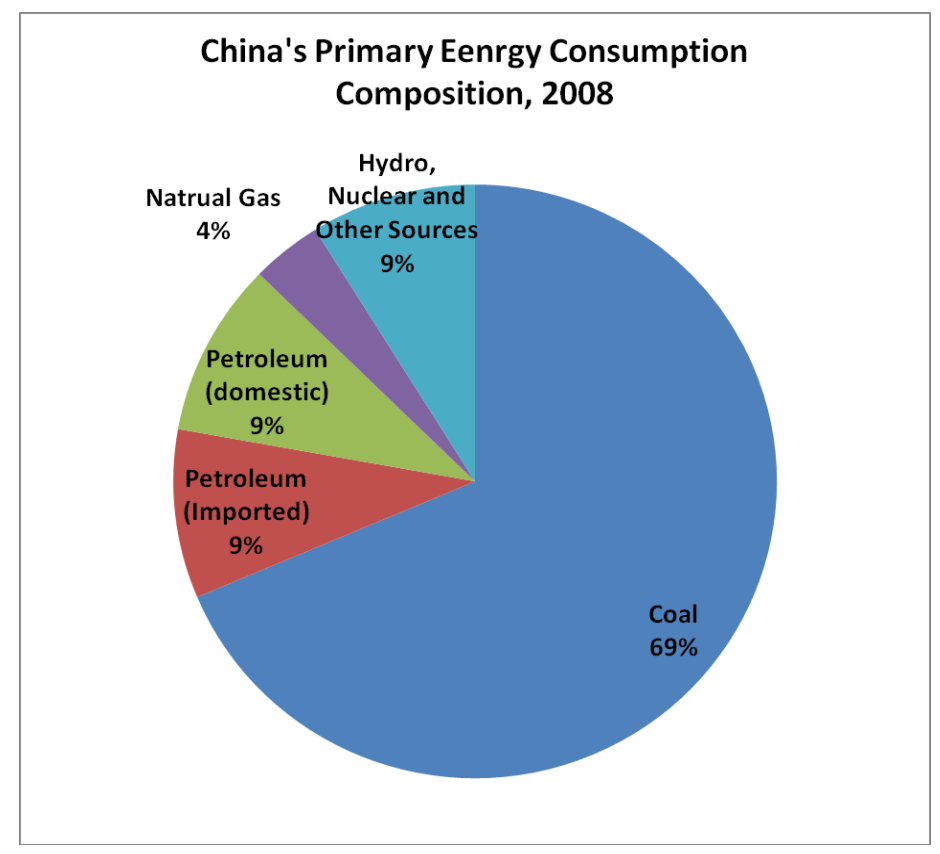

As shown in Table 1 and Figure 9-11, the single most important feature of China's energy production and consumption structure is a high level of dependence on coal. The demand for coal has always been over 70 percent in total primary energy consumption in the last decades. Oil demand has been growing quickly, with its share of primary demand reaching 20 percent in mid-1990s. But it has been declining in recent years. Natural gas and the country's many hydropower projects contribute about 10 percent consumption. Nuclear power and renewable power contribute just over 1 percent (NBS, 2009).

${ }^{28}$ Ibid. 


\subsubsection{The Coal Situation}

China is both the largest producer and consumer of coal in the world. According to Chinese government statistics, China has 400 billion tons of exploitable proven coal reserves. Based on the coal production volume in 2007, China's coal reserves can meet the domestic coal demand for the next 80 years (Cui, 2008: 34). The IEA estimates that China's remaining coal resources are second only to Russia's in the world, totalling 1003 billion tons, but only 115 billion tons can be regarded as proven reserves, yielding a reserve-to-production ratio of around 50 years (OECD/IEA, 2007a: 334). Although the estimates by different agents various, there is no doubt that domestic coal reserves will meet the bulk of its domestic demand in the foreseeable future.

From 1949 to 2006, China's coal production increased at an annual rate of 8 percent, producing 40.5 billion tons of coal in total, which not only met the domestic demand, but also has been exported as a trade commodity. In the seven years from 2000 to 2006 alone, China produced 11 billion tons of coal, which accounted for 27 percent of the total coal production in the 57 years from 1949 to 2006 (Cui, 2008: 49). In 2008 , coal production was approximately 2.72 billion metric tons, accounting for almost 77 percent of domestic primary energy production and about 40 percent of the world's production of coal (Peng, 2010: 1).

In 2008, China consumed 2.85 billion tons of coal, representing 68.7 percent of the country's total primary energy demand, which is a 106 percent increase since 2000 
(NBS, 2009). Although since the mid-1990s the demand for coal had slightly declined, coal consumption has been on the rise in China over the last decade and becomes increasingly important to China's economy. In terms of end use, more than half of China's coal consumption is transferred into the main secondary energy electricity, which makes the electric power sector the largest and most important consumer of coal (NBS, 2009). Since 2006, nearly 90 percent of new powergeneration capacity has been made coal-fired, which makes China's electric power generation heavily depend on coal domestic production and transport capacity (OECD/IEA, 2007a: 264). The coal which were transferred to electricity plus hydro and nuclear electric power collectively accounted for about 40 percent of total primary energy demand in 2007, making domestic electric power supply a key determinant to China's economy (Cui, 2008; NBS, 2009).

Given the vast territory and the geographic mismatch of major coal producing regions and consuming regions, ${ }^{29}$ the transportation of coal has been a key factor determining China's energy economy performance in the last 40 years. Since 2001, coal transportation has accounted for no less than half of the national railway capacity and a quarter of the highway capacity. As the main inter-provincial energy transportation, railway shipments of coal reached 1.2 billion tons in 2007, accounting for almost half of China's coal production in that year and half of total

\footnotetext{
${ }^{29}$ There are 27 out of 32 provinces and regions in China that produce coal. But the geographic distribution of coal resource is quite uneven across regions, the major deposits are found in the Northern China, especially Shanxi Province (山西), contains most of China's easily accessible coal (over 100 billion metric tons) and virtually all of the large state-owned mines. Other coal producing areas are mainly located in the North (Inner Mongolia), Southwest (Guizhou and Yunnan) and Northwest (Shaanxi, 陕西). See Hengyun Ma, "China's Energy Economy: Reforms, Market Development, Factor Substitution and the Determinants of Energy Intensity" (PhD Thesis, University of Canterbury, 2009). p 80.
} 
railway cargo (Ma, 2009: 86; NBS, 2009). China's domestic coal flow is generally from the coal abundant region in the northwest to the southeast coastal provinces (北 煤南运, 西煤东运) where the more economically developed and thus major energy consumers are located. However, due to the limited capacity of the transportation system, at least 0.2 billion tons of coal could not be delivered to energy consumers in 2006, accounting for about 8 percent of coal consumption of that year (Cui, 2008: 54). The situation has not been improved much recently. The limited energy transportation capacity has become a major cause of inter-provincial high way traffic congestion (Anderlini, 2010), which also caused the disruptions of domestic coal supplies and led to coal price increase (Xinhua, 2010).

\subsubsection{The Oil Situation}

As the second largest primary energy source, the share of oil in primary energy consumption is much lower than that of IWCs, accounting for only 18.7 percent in 2008 (See Table 1 and Figure 11). Although the absolute quantity of oil has been increasing, its share in primary energy consumption has been declining in recent years. According to Chinese government statistics, China consumed $365 \mathrm{mmt}$ (7.3 million bbl/d) of crude oil in 2008, making it the second-largest oil consumer in the world only behind the United States (Chinese Central Gov, 2009).

China is also a large oil producer. The total output of crude oil in China was 190 mmt (3.8 million bbl/d) in 2008, making it surpass Iran to became the world's fourth largest oil producer after Saudi Arabia, Russia and United States (NBS, 2009; EIA, 
2010). China has made significant efforts to stabilize its crude oil output and increase it. From 2005 to 2008 , the crude oil output had increased from $181 \mathrm{mmt}$ (3.6 million $\mathrm{bbl} / \mathrm{d}$ ) to $190 \mathrm{mmt}$ (3.8 million $\mathrm{bbl} / \mathrm{d})$, a growth rate of almost 3 percent annually (NBS, 2009). Nevertheless, since 1998 the share of crude oil in domestic primary energy production has declined from 18.1 percent in 2000 to 10.4 percent in 2008 (See Table 1 and Figure 9).

As has been well documented by various literatures, crude oil consumption surpassed its production in 1993 and China has since become a net oil importer. In 2008, its crude oil imports reached approximately $175 \mathrm{mmt}$ (3.5 million bbl/d), making China the world's third largest oil importer behind the United States and Japan (See Figure 12). From 1993 to 2008, the oil import-consumption ratio rose from 4.7 percent to 47.9 percent, a ten-fold sharp increase (See Table 1). 
Figure 12 Top Ten Net Oil Importers in the World, $\mathbf{2 0 0 8}^{30}$

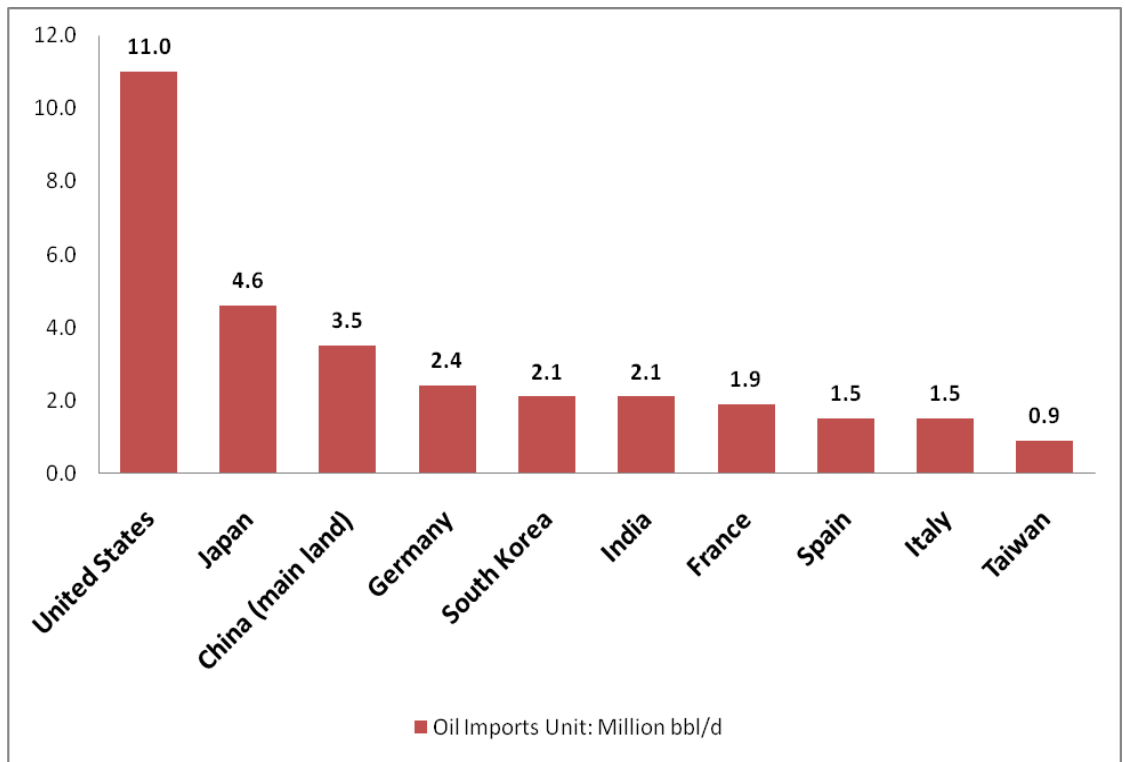

Figure 13 China's Oil Imports by Countries of Origin, $2008^{31}$

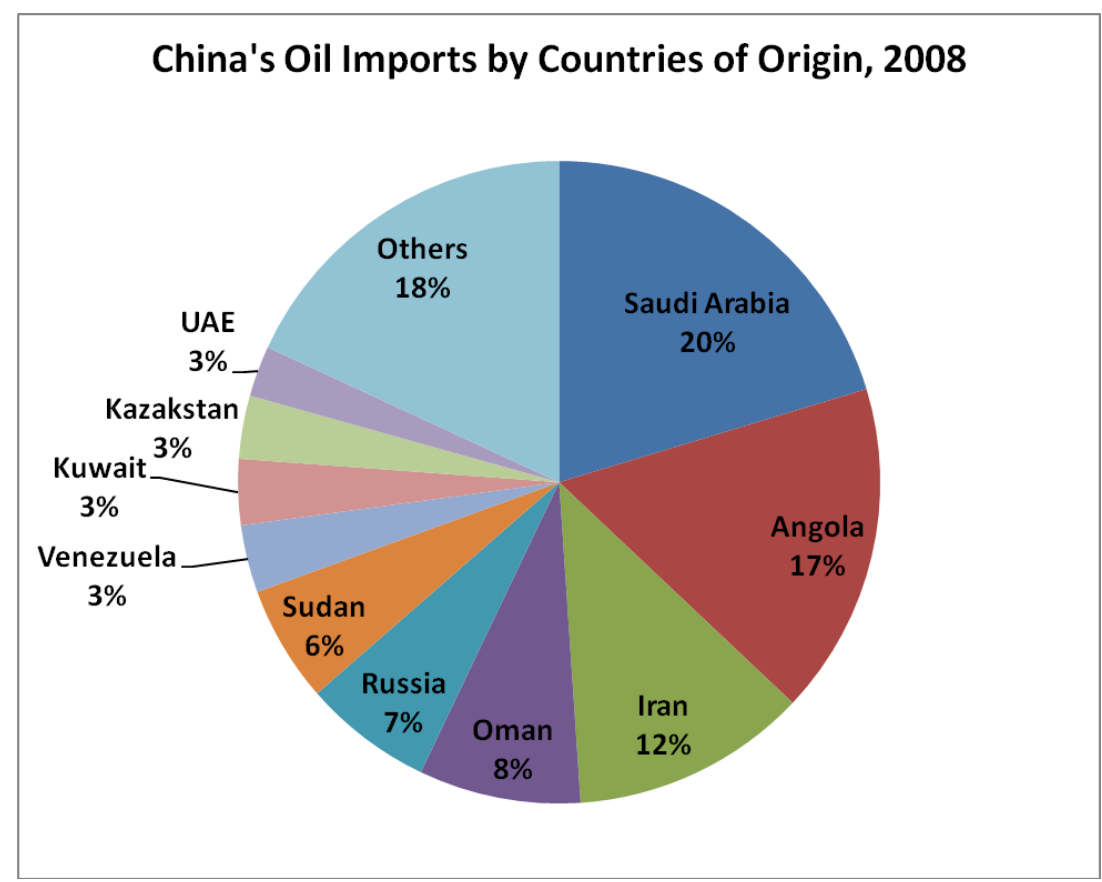

${ }^{30}$ Data Source: EIA. "International Energy Statistics".

${ }^{31}$ Data Source: EIA. "Country Analysis Briefs: China". U.S. Energy Information Administration. Accessed in August, 2010, http://www.eia.doe.gov. 
The fact that China's oil import dependence has almost reached 50 percent, and the oil import sources are quite similar with the Western countries concern Chinese leaders and analysts the most (See Figure 11 and 13). As shown in Figure 13, in term of oil imports by country and region, the Middle East remains the largest oil source, although African countries also contribute a significant amount. Among the Chinese oil imports in 2008, about 1.8 million bbl/d, which means half of the imported oil came from the Middle East; 1.1 million bbl/d (30 percent) from Africa; 101,000 bbl/d (3 percent) from the Asia-Pacific region; and 603,000 bbl/d came from other countries and regions. A similar pattern is evident in import data from the first five months of 2009 (EIA, 2010f).

\subsubsection{Other Primary Energy Sources}

As shown in Figure 11, natural gas, hydro and nuclear power collectively accounted for just 13 percent of China's consumption in 2008. Historically, natural gas has never been a major energy source in China, but its share in the country's consumption mix is increasing slowly. In 2007, the country consumed 70.4 billion cubic meters (BCM) natural gas and, for the first time in almost two decades, China became a net natural gas importer. Consumption for 2007 rose from 2006 levels by about 16.7 percent, and the country began to import liquefied natural gas (LNG), amounting to nearly $4 \mathrm{BCM}$ in 2007 . In 2009 this figure rose to $5 \mathrm{BCM}$, accounted for 6 percent of the China natural gas consumption in 2009 (NBS, 2009; EIA, 2010f). 
China is rich in hydropower. Maximum exploitable hydropower resources are approximately 680 million $\mathrm{KW}$, of which $380-400$ million $\mathrm{KW}$ is currently exploitable. China's hydropower production has grown fast during the last decade, from 1906 billion $\mathrm{kWh}$ in 1995 to 4829 billion $\mathrm{kWh}$ in 2007. This represents an annual growth rate of approximately 8 percent. In 2007, the share of hydropower in electricity generation was 18.4 percent, and its share in total energy consumption was approximately 6 percent (Ma, 2009: 81; NBS, 2009).

The share of nuclear power in consumption has grown rapidly from $12.8 \mathrm{kWh}$ in 1995 to 62.9 billion $\mathrm{kWh}$ in 2007 , representing an annual growth rate close to 15 percent. In 2009, there are 11 operational nuclear power units in China, with an installed capacity of 9100 Megawatt (MW). However, the share of nuclear energy is very small in total electricity generation, only 1.9 percent in 2007. Moreover, its share in both total energy production and consumption is lower than 1 percent (NBS, 2009; WNA, 2010a).

Facing grave environmental problems caused by the use of fossil fuel, the Chinese government is accelerating the investment and development of renewable energy sources such as wind and solar energy. In 2009, China overtook the United States as the largest renewable and clean energy investor in the world. China invested USD 34.6 billion in renewable energy, a 147 percent increase since 2005 and almost twice as much as the United States did in 2009 (Rogers, 2010). China has also leapfrogged the West in the last two years to emerge as the world's largest manufacturer of solar panels. Although currently such renewable energy sources provide only four percent 
electricity generation capacity and only 0.1 percent of total energy consumption, the Chinese government plans for wind, solar and biomass energy to represent eight percent of its electricity generation capacity by 2020 (Bradsher, 2010).

In sum, in a comprehensive picture of Chinese domestic energy situation, coal is undoubtedly the most important energy source in two ways. First, coal is the most widely used fossil fuel in China's economic system, and the share of coal demand always accounts for about 70 percent in China. And this share remains stable in the last decades, which means China remains a coal-based economy. Second, coal provides fuel for 76 percent of China's electric power generation capacity (EIA, 2010f). Electric power is vital to economic growth (the electricity-economy relation will be analysed in the following chapter). In contrast, oil only accounts for less than 20 percent primary energy consumption, and its share has been declining in recent years. Other energy sources collectively only account for about 13 percent of consumption but, due to the heavy pollution and a variety of environmental problems caused by the use of fossil fuel, the Chinese government is encouraging the development of these energy sources and strives to enhance their share in consumption. 


\subsection{China's Energy Security: the Salience of the Traditional}

\section{Approach}

Although in China, oil does not play as important a role as in the IWCs, the energy security discourse in China is characterized by an overwhelming focus on the security of external oil supply. For China, a fast growing emerging economy that has joined the energy importers' club for no more than two decades, energy security is a fairly new topic. Thus, to examine the linkage between energy and security becomes an urgent task for Chinese scholars and policy makers. The Chinese literature on energy security has increased rapidly since the mid-1990s. To date, mainstream energy security thinking in China shares the characteristics of the Western traditional energy security approach (Downs, 2004; Downs, 2006). Two factors are important to explain this. First, as a symbol of its 'self-reliance' doctrine dating back to the Maoist era, both Chinese scholars and its political leaders are psychologically more sensitive to China's growing oil deficit than other energy security issues. Second, the Chinese scholars and leadership have adopted the traditional energy security thinking to analyze its energy security issues. Thus, a traditional energy security approach also dominates China's energy security studying and policy making. 


\subsubsection{The Doctrine of Self-Reliance}

The doctrine of 'self-reliance' (自力更生) did not emerge as a widely proclaimed official policy guideline in China until its break with the Soviet Union in the late 1950s. In the first decade after the founding of the People's Republic of China (PRC) in 1949, the Western response to the Communist revolution was such that the new regime had no viable option but reliance on the Soviet Union. But the period of dependence proved to be short-lived. By 1958, the constraints and costs of reliance on the Soviet Union became increasingly apparent to the Chinese leadership, particular to the Party Chairman Mao Zedong and State Premier Zhou Enlai. The Soviets' sudden withdrawal of economic and military aid from China brought a severe blow to PRC's modernizing economy and obliged the Chinese leaders to learn the painful consequences of the 'leaning-to-one-side' (一边倒) policy of dependent development. China's difficulties at this time were further aggravated by the continuous Western strategic embargo led by the United States. Consequently, these developments in the 1950s led some observers to conclude that self-reliance was an involuntary choice thrust upon China by the combination of the 'two hostile external powers' (U.S. and Soviet Union). In this view, self-reliance was made a "virtue out of necessity" by the Chinese (Ray, 1975: 74; Wu, 1981: 453). In terms of economic development and national defence, energy self-reliance is of particularly importance to China.

In the wake of the Civil War in 1949, China relied almost entirely on biomass and coal for the needs of its mainly rural population as well as its limited and war-torn 
industrial sector. Although the Chinese Communist Party (CCP) set ambitious goals for industrialization, with almost no domestic oil production and the embargo, energy development was an urgent task facing the PRC. China began to establish its own energy industry during the first Five Year Plan (1953-57) with aid from Soviet Union. Its energy demand during the 1950s substantially exceeded domestic supply, especially in terms of oil. The gap was filled by imports from the Soviet Union. During the $1950 \mathrm{~s}$, these amounted to 14 million metric tons (mmt), with a peak in 1959 of three mmt, of which $2.4 \mathrm{mmt}$ were petroleum and the balance was crude oil. In total, China imported more than $24 \mathrm{mmt}$ at a cost of over USD 1 billion (Tatsu and Christopher, 2007: 12).

In 1963, largely due to the discovery of several major domestic oil fields in Eastern China and increasing coal production, China achieved overall energy selfsufficiency, which became a pre-eminent symbol of 'self-reliance'. By 1963, the crude oil production of the major oil field - Daqing oil field - reached $9 \mathrm{mmt}$ per annum. By 1966 the oil from Daqing reached $10.6 \mathrm{mmt}$. In the same year imports of Soviet oil fell to only 40,000 mmt (Tatsu and Christopher, 2007: 24). Thus, the Chinese leadership proudly declared that they were now "self-reliant" in their supply of oil. Zhou Enlai made his famous oil self-reliance remarks in the Second National People's Congress held by the end of 1963 . He said: “.... our country's economic construction, the oil needs for defence and civilian applications which had depended on foreign imports in the past, are now basically self-reliant, whether in volume or in variety" (Lim, 2009: 4). This declaration was also described in Chinese official media as a "glorious war result" (辉煌战绩) was constructed as a befitting end to the 
“Eastern giant's” (东方大国) longstanding slavish dependence on foreign energy supplies (Chen, 1994: 300).

In the wake of Cultural Revolution in the mid-1970s, China's economy was on the verge of collapse. But energy self-reliance was still guaranteed. At that time, the first energy crisis enabled China to export its oil surplus at high prices, mainly to Japan. China's first export shipment of crude oil was made to Japan in 1973, and this particular market expanded rapidly in the aftermath of the OAPEC oil embargo and price increases of that year. Oil and coal became the primary export commodity for China in exchange for hard currency (Owen and Neal, 1989: 489). In the following 30 years, the Daqing oil field alone exported some $200 \mathrm{mmt}$ of crude oil to Japan (Tatsu and Christopher, 2007: 24). Although the launch of economic reforms in the late 1970s and consequent fast economic growth created increasing energy demand and pushed China away from energy self-reliance, the Chinese leadership still firmly maintained the doctrine. Deng Xiaoping who went before the Sixth Special Session of the UN General Assembly in 1974 stressed that: "By self-reliance we mean that a country should rely on the strength and wisdom of its own people, control its own resources, strive hard to increase food production, and develop its national economy step by step in a planned way." (Lee, 1995: 188)

Since the early 1980s, the energy demand of the expanding industry sector has to be met by huge investment in energy supply infrastructure and substantial quantity of energy imports. As a result, China began to import crude oil from Oman in 1983, originally as a temporary measure to deal with the domestic transportation 
bottleneck in conveying oil from the fields in the north to refineries located in the south of China (Zha, 2010: 3). China's crude oil exports peaked in 1985, reaching 30 mmt. But from 1988, oil imports began to rise rapidly. In 1993, the country became a net oil importer (Zha, 2010: 3). Meanwhile, China's coal export was still increasing, and it was not until 1996 that China became a net energy importer (NBS, 2009).

China's loss of energy self-sufficiency is an unprecedented situation facing the new generation of Chinese leaders, whose predecessors were guided by the self-reliance doctrine. Although the scholar and policy makers in Beijing long ago realized the inevitability of oil dependence, the hope for self-reliance, realistic or not, is still firmly rooted in China's philosophy and logic of energy security thinking (Ding, 2008). Therefore, the Chinese are psychologically more sensitive to its oil deficit than any other energy issues, even though the economy security implication of oil deficit is far less urgent than the problematic coal-electric power situation (which will be analyzed in the following chapter). As Erica Downs notes, China's energy security policies "can be explained in terms of China's long lasting fear of dependency on foreign energy" (Downs, 2004: 6). Nonetheless, besides the ideational factor, there are also realistic concerns about the negative impact energy dependence might have on national security as in the energy crises. 


\subsubsection{The Influence of the Western Approach}

Besides the ideational factor of energy self-reliance, Beijing's view on energy security is also largely influenced by Western energy security thinking. Chinese analysts and decision-makers have been looking closely at the IWCs' experiences of energy insecurity and their strategies to alleviate energy dependence (Constantin, 2005: 9; Ren and Sun, 2007). This influence is mainly reflected in the energy security concept that Beijing adopted and the strategic foreign policy response to its 'energy insecurity'.

This should not come as too much of a surprise given that many influential Chinese specialists openly advocate learning the lessons of the West, while others simply adopt the concepts and recommendations found in the Western literature on energy security (Constantin, 2005: 10). A significant number of influential scholarly works define energy security in accordance with their Western counterparts, especially Daniel Yergin's definition that emphasises the availability, reliability and affordability of energy supply (Liu and Qin, 2002; Zhang, 2003; Xu and Yang, 2004; Zha, 2005; Lin and Downs, 2006; Guan and Fan, 2007; Song, 2008; Wu and Liu, 2009). And most of this literature cites the Western experience of external supply and market risks. Therefore, it is a common perception in China that its "energy security problem is its growing oil deficit" (Downs, 2004: 23).

Since most of the scholarly research is funded or conducted by the Chinese authorities which decide the priority of the energy security policy (Cheng, 2008), 
This conceptualization of energy security in China has been reflected and strengthened by the ideas of China's political leadership in the last two decades. In the early 1990s, the traditional approach already began to influence Chinese leaders' energy security thinking. As early as 1993, the then-Premier Li Peng set the stage for this approach by defining the objectives of the country's energy policy as "to secure the long-term and stable supply of oil to China" (Chang, 2001: 233). This fundamental objective guided most of the energy decisions taken during the rest of the decade (Constantin, 2005: 11).

In the first decade of this century, this approach continues to prevail. Energy security topped the list of strategies to develop the energy sector in the 2001 "Tenth FiveYear Plan of Economic and Social Development" (NDRC, 2001). The salience of this traditional approach was also evidenced at a central economic work conference on November 29, 2003, where CCP Central Committee General Secretary and State President $\mathrm{Hu}$ Jintao conceptualized oil and finance as the two national economic security issues (People's Daily, July 19 2005). As one government-supported study concludes, "from the long-term and global point of view, energy security more accurately is oil security" (Feng, et al., 2004: 12). This understanding of energy security is also revealed in many Chinese scholarly works: energy security is often associated with energy or oil geopolitics or the struggle among great powers to reach pre-eminence. Recommendations proffered by these academics to policy-makers, in general, stay close to the supply-sided strategies mentioned above while they tend to emphasize diversification of supply sources diplomacy and the development of 
pipeline transportation to lower the risk of China being subjected to an embargo (Jiashu, 2001; Amuti and Zhang, 2003; Xia, 2003; Zhang and Guan, 2007).

Therefore, guided by a traditional approach, China perceives its primary energy security vulnerability as an external dependence, mainly oil import dependence issue. The energy security threats China faces are supply disruptions and oil market volatility. This concept has been largely directing Beijing's energy security policies in the last one and half decades. 


\subsubsection{Strategic-Foreign Policy Response to 'Energy Insecurity'}

\section{i. The Disruptions of Energy Supply}

Most Chinese analysts are worried about the reliability of oil imports both from its sources of supply and from transport through the Sea Lines of Communications (SLOCs). The former concern stems from the fact that China imports oil from about 30 countries, the majority being less than stable countries in the Middle East and Africa (See Figure 5). As a result of this concentration, China perceives its oil imports can easily be affected by the unstable geopolitical situation in these two regions (Kong, 2005; Ning, 2009). However, a key feature of Chinese strategic thinking on energy security is that there has been increasing discourse about the 'collateral damage' on oil imports reliability from adversary powers' actions in the regions, mainly U.S. and its allies. The concern is that the instability caused by U.S. diplomatic and military actions in China's primary oil supply regions will negatively affect its imports stability and long-term access to oil resources.

Although commonly cited concerns are about the vulnerability in the SLOCs include the threat from piracy, articles and news reports always cite the fear of U.S. hegemony in the region as their primary source of concern over this bottleneck in oil imports (Liu and Qin, 2002; Wang, 2007; Zhao, 2007). As 93 percent of China's oil imports are shipped by sea, 90 percent of which are shipped by international tankers and more than 80 percent of which are shipped through the Malacca Strait, the possibility of a deliberate interruption of energy supply by the potential adversary 
powers pose one of the biggest threats to China's energy security (Kong, 2005: 15). Given that the most of the energy SLOCs are patrolled or jointly patrolled by the US navy or the navies of its allies, whose intentions are dubious to Chinese, the fact that China has to rely on the United States to guarantee safe passage makes China feel very uncomfortable. As scholars from China Institute of International Studies and China Academy of Social Sciences point out, at present China does not have enough military projection capability to protect the key energy SLOCs (Zhang, 2003), and in the event of regional military confrontation, "U.S. and its allies along the strait (of Malacca) have the capability and will probably block the strait as a strategic leverage against China" (Zhang, 2005: 18). In fact, some Chinese scholars think that the United States, threatened by China's rise, sees China as a competitor and will attempt to contain China by using oil supplies as a convenient instrument as it did to Japan in the World War II (Shu and Yan, 2004). The Chinese analysts who consider the worst case scenarios, identify China's growing reliance on imported oil as a vulnerability that could be exploited by the U.S. and its allies in the event of a SinoAmerican confrontation across the Taiwan Strait or conflict between the two countries in the Asia-Pacific (Jiang, 2001; Zhang, 2003; Gu, 2004). As a result, worries about the reliability of China's oil imports are evident in the top leadership's thinking. At the central economic work conference in 2003, Hu Jintao reportedly expressed extreme concerns over the "Malacca dilemma" that bears on China's oil security (People's Daily, July 19, 2005).

The leadership's concern about the security of China's seaborne energy imports and a desire to diversify its oil supplies away from the Middle East, as well as diversify 
the energy transport route from a few SLOCs have sparked Chinese interest in investing in Russian and Central Asian oil field development projects and in the construction of large diameter, long-distance pipelines to China from these regions. Analysts from Chinese academia regard participation in the development of Russian and Central Asian energy resources as an important source of energy security (Feng, 2004; Wang, 2006; Fu, 2009). They maintain that oil imported overland by pipeline would be less vulnerable to disruption by the United States than oil arriving by tanker (Zhang, 1998).

Since the turn of the century, China has started several oil pipelines projects. Beijing reached an agreement with Moscow in 2001 to build an oil pipeline from Angarsk in Russia's East Siberia to Daqing in Northeast China. But seduced by Japan's offer of providing USD 7.5 billion to finance building a longer pipeline from Angarsk to Nakhodka, the Russian government pit Chinese against Japanese to maximize benefits by exporting more energy to multiple buyers. Irritated by the uncertainties involved in the Russia-China pipeline, the Chinese government decided to put the once-sidelined Kazak-China pipeline on the front burner (Kong, 2005: 41). As a result, construction of the 1300-kilometer long pipeline from Atasu in Kazakhstan to Alashankou in Xinjiang was launched on September 28, 2004, and the first phase of the project has completed on December 12, 2005 and has 20 million tons per annum (400, $000 \mathrm{bbl} / \mathrm{d}$ ) oil transportation capacity, and the second phase of the project is expected to completed by 2012 (People's Daily, Dec 15, 2005). Alarmed by the possibility of losing its oil market to Kazakhstan and frustrated by Japan's insistence that the pipeline issue be linked to the disputed Kurile Islands, the then-Russian 
President Putin declared during the G8 meeting in July 2005 that Russia will build the China section of the Taishet-Nakhodka pipeline. It will be built to ship 20 million tons of oil $(400,000 \mathrm{bbl} / \mathrm{d})$ to China's Daqing per annum and an additional 10 million tons $(200,000 \mathrm{bbl} / \mathrm{d})$ will be sent on railway to Nakhodka. Construction of the first phase of the pipeline has been completed in August 2010 and put into test. On completion, the Kazakh and Russian pipelines will provide 30 million tons of oil to China annually $(600,000 \mathrm{bbl} / \mathrm{d})$, thus reducing the country's dependence on the Middle East by at least 20 percent (Sun, 2010). This 'pipeline incident' among Russia, China and Japan strengthened Beijing's perception that the security of energy supply is an important part of geopolitics competition, which is in consistency with Western experiences (Ning, 2009).

Besides pipelines building, the Chinese government has also made great efforts to expand its domestic oil tanker fleet to ship its oil imports and to expand the navy fleet to protect its oil imports. According to an official report in 2004, in an attempt to improve the country's oil transport security the Chinese government will invest in a USD10 billion program to allow its domestic crude tanker fleet to ship half of the country's total imports in the future (China Daily, Jan 7, 2004). Meanwhile, as part of China's military modernization drive, it is speeding up its navy upgrading to build a 'blue water' navy. Although it still does not have a sufficient power projection capacity yet, the long-term goal dictates that the military modernization will eventually allow China to protect the key SLOCs through which its oil imports go through, by the Chinese navy (Gu, 2004; Kong, 2005: 43). In January 2009, the first group of Chinese naval ships sailed into the Gulf of Aden to join the international 
anti-piracy fleet, making the first step to protect the energy SLOCs far from China's traditional sphere of influence (Wang and Du, 2009).

Although China has made significant efforts to diversify the petroleum import sources and transportation routes, the United States' reactions to the 9/11 terrorist attacks and the 2003 Iraq War strengthened the fears of strategic insecurity of China's energy supply. Although the incidents have not led to direct reallocation of oil resources around the world, China is very distrustful of the United States' long term intentions in Central Asia, particularly as it deployed its armed forces in this region after 9/11. According to a scholar from the Development Research Centre of the State Council in Beijing, U.S. inroads into Central Asia after 9/11 allowed it to 'kill three birds with one stone': to control the strategic area of Central Asia, to contain China, Iran and Russia, and to control oil and natural gas resources in the Caspian Sea region (Qin, 2004). Since China had been seeking to reduce its reliance on oil shipments through the key SLOCs by trying to build oil pipelines from Russia and Central Asia, the U.S. military presence in the region, in the Chinese view, constitute a major threat to its oil imports reliability. Some Chinese analysts have gone even further to suggest that "the terrorist attacks on September 11 have objectively provided a pretext for the United States to enter Central Asia in a way to complicate an environment which originally was straightforward for China. This will be of far-reaching significance to the strategy of oil supply in China" (People's Daily, Sep 24, 2001). 
Although China only imported only 0.8 percent of its total oil from Iraq in 2002, the war in Iraq took place in a region which supplied half of its oil imports in that year (Kong, 2005: 27). The Chinese energy academia and government followed the war very closely and were extremely concerned about its implications to China's oil security. In fact, some Chinese analysts believe that the war in Iraq was motivated by a U.S. desire to control oil resources in the Middle East (Wu, 2003; Shu and Yan, 2004; Qin, 2004). Therefore it affected China's energy security profoundly. In Chinese view, the war in Iraq negatively influenced the reliability of China's oil imports from the Middle East. The concern is plainly demonstrated by the title of a special report run by CCP's official newspaper - People's Daily, “The Suspense of the US War Against Iraq: Will the 70,000 Barrels of Oil from the Middle East be Shipped Safely to China?" (Li, 2003). Evidently, China is concerned that the war in Iraq might interfere with the availability of the country's oil imports from Iraq or other countries in the Middle East (Kong, 2005: 27).

\section{ii. The Volatilities of World Energy Market}

Concerns about the availability and reliability are both tied to China's perceptions about the affordability of its external energy supply. As the sharp rise in oil price is a serious concern in China, Chinese academics have produced substantial research on the trends of oil markets in the last decade (Zuo and Yao, 2001; Wang, 2003; Zhou, 2004; Gao, 2005; Xing, 2005; Liu, 2005; Yu, 2006; Zhang and Guan, 2007; Zhou and Zhu, 2009). Most of it focuses on the mechanisms and factors determining international oil prices, advanced industrial countries' policy responses to high oil 
prices, the latter's impact on China, and the policy responses of the Chinese authorities. These studies tend to have a negative view of high oil markets, highlighting issues such as China's loss of wealth and fluctuations in the exchange rate of the Chinese currency (Cheng, 2008). Thus, the negative impact of oil market volatilities on China's economy and social stability is also a main concern of Chinese policy makers and analysts, only next to the disruptions of supply. As a developing country, China perceives itself more vulnerable to oil market swings than industrialized nations (Downs, 2004; Zhang and Guan, 2007).

In general, a significant number of Chinese analysts are distrustful of the world energy market and tend to view the prices of the world's oil resources as manipulated by major international monopoly capital, international speculation capitals and China as a victim of all those countries with the power to manipulate the oil markets (Zhang, 2005a; Cao, 2007). Given China's increasing dependence upon foreign oil, high oil prices are particularly perceived as inimical to its economy since they will increase outflow of its foreign exchange reserves and affect its balance of payment (Zhang, et al., 2002). More importantly, the government is extremely concerned that high oil prices will slow down China's GDP growth, which underpins its stability and the survival of the political regime (Downs, 2004; Kong, 2005).

Therefore, in order to strengthen the country's ability to withstand energy market fluctuations, Chinese scholars and authorities believe that they should begin to establish a Strategic Petroleum Reserve (SPR). According to the Western experience of supply risks, SPR is commonly perceived as the most effective way to alleviate 
the impact of supply disruptions and consequent market volatilities. The Chinese analysts noticed U.S. and other IEA members stabilized the world oil markets by releasing their oil stocks shortly after the prices hiking caused by the Iraq's invasion of Kuwait and the following Gulf War in 1990-91 (Fu, 1992; CPCI, 2003). They are also aware that Japan and South Korea (as members of the IEA) ${ }^{32}$ have SPR which can last for 169 days and 75 days respectively; that Singapore and Thailand have strategic oil reserves lasting for 44 days and 36 days respectively. In contrast, the oil reserves of China can only satisfy between one and two weeks of their respective domestic needs at the turn of the century (Cheng, 2008: 303).

Since the late 1990s, Chinese scholars has been advocating the establish of Chinese SPR (Zhao and Li, 1999). As a result, the Chinese central leadership established the State Strategic Petroleum Reserves Office in 2003 under the National Development and Reform Commission (NDRC) and charged it with the mission to set up China's SPR system. In the same year, the construction of four SPR bases was started in Zhenhai (Zhejiang Province), Daishan (Zhejiang Province), Huangdao (Shandong Province) and Dalian (Liaoning Province) (People's Daily, Oct 8, 2006). The first stage of the programme has been completed in 2007. Upon completion, the four bases will altogether form a government strategic reserve capacity equivalent to the country's crude imports in 10 days, adding the country's 21 days of commercial oil reserves. Moreover, this is only the first step toward a long-term goal set by the government to achieve a SPR capacity of 90 days by 2015 (Xinhua, July 28, 2006; CCS, 2007).

\footnotetext{
${ }^{32}$ IEA net oil importing countries have legal obligation to hold emergency oil equivalent to at least 90 days of net oil imports of the previous year. See OECD/IEA. "IEA Response System for Oil Supply Emergencies". International Energy Agency. Accessed in August, 2010, http://www.IEA.org/textbase/nppdf/free/response_system.pdf.
} 


\section{iii. Overseas Energy Investment and Energy Diplomacy}

Because of the perception of China's oil supply insecurity and its limited comprehensive power, Chinese authority has largely adopted an approach which is similar to the IWCs' overseas energy investments and diplomacy after the energy crises. $^{33}$

At the end of 1992, the Chinese leadership, especially the then-CCP General Secretary and State President Jiang Zemin, proposed that China's development strategy would have to "fully exploit domestic and foreign resources and markets" (Chen, 2008). Supported by the government, the major energy enterprises began 'going out' (走出去) to acquire overseas oil assets, which has been criticized by some Western analysts as 'nationalist' or 'mercantilist' behavior in recent years (Palti, 2007: 11). Thus, under the government's 'Going Out' or 'Going Global' policy (“走出去”战略), the major national oil companies (NOCs) of China, namely China National Petroleum Corporation (CNPC), China National Offshore Oil Corporation (CNOOC) and China Petroleum \& Chemical Corporation (Sinopec), have begun their overseas acquisition programmes.

In March 1993, CNPC successfully bid for an oilfield in Peru, marking the first entry of China's petroleum industry into the international market (Cheng, 2008: 313). By 2005, the three majors had invested over USD 7 billion in Africa, Central Asia,

\footnotetext{
${ }^{33}$ For instance the 'Going Out' strategy parallels the Japanese government's decision to provide financial and political incentives and help for Japanese oil companies to invest in overseas oil production after the first oil shock. See Clay Chandler, "Can China Keep the Lights On?," Fortune, Febuary, 23, 2004.
} 
Oceania and Latin America, involving over 60 international oil and natural gas projects in 30 countries. Through these investment projects, China's major oil companies controlled oil reserves in excess of 600 million tons, and secured oil shares from 3 million tons in 1999 to over 12 million tons in 2002 and more than 15 million tons in 2005 (Zhang and Huang, 2006: 183).

The oil companies' overseas investments have focused on the purchase of equity positions in already discovered oil fields. In most countries, the government owns the oil in the ground, and the foreign company buys into an agreement, such as a production sharing contract, under which the company pays a certain amount to extract oil and the company and the government split the output (Downs, 2004: 34). In 2001, Chinese NOCs produced 180,000 bbl/d of 'equity oil' (份额油) overseas, constituting about 15 percent of oil imports for that year (Tian, 2002: 11). CNPC's foreign oil and gas output in 2006 reached 59.14 million metric tons of oil equivalent (Mtoe), an increase of 51.5 percent over the previous year. During the same year, China Petroleum \& Chemical Corporation (Sinopec) gained 5.5 million tons of equity oil production, more than twice the figure of 2005. By the end of 2006, China National Offshore Oil Corporation's (CNOOC) overseas net production captured 1.2 million tons of crude oil, condensate and natural gas liquids as well as 130.3 million cubic feet of natural gas (Chen, 2008a: 80). Analysts expect that in 2010, China will import 50 million tons ( 1 million bbl/d) equity oil, accounting for about one quarter of total oil import of the year (Liu, 2006). Beijing considers the acquisition of equity oil is of great importance to China's energy security, as the 
Chinese leadership believes that China cannot depend on Western oil companies or the international oil market in times of crisis (Zhang and Guan, 2007).

Nevertheless, this 'Going Out' is not going without setbacks, especially considering the strategic significance and national security implications of energy resources to other countries. In June 2005, CNOOC made an all-cash USD 18.5 billion offer to buy American oil company Unocal Corporation ${ }^{34}$, topping an earlier bid by ChevronTexaco. However, a broad group of Democrats and Republicans in U.S. Congress jointly organized opposition to the CNOOC bid. They argued that with USD 13 billion of CNOOC's bid for Unocal coming from the Chinese government, the offer did not represent a free market transaction and had questionable motives (Bullock and Xiao, 2005). As one article in the New York Times comments, "The takeover offer has prompted a gathering groundswell in Congress to make sure oil is defined as a product vital to America's national security" (Lohr, 2005). It was argued by the U.S. Congress that the foreign and particularly communist ownership of oil assets could represent a regional and economic security risk and that Unocal also had sensitive deep-sea exploration and drilling technology with dual-use potential (Bullock and Xiao, 2005).

As a result, on July 20, Unocal announced that it had accepted an increased buyout offer from ChevronTexaco for USD 17.1 billion. On August 2, CNOOC announced that it had withdrawn its bid, citing strong political opposition from the U.S.

\footnotetext{
${ }^{34}$ Unocal was once the major oil producer in southern Alaska and a major natural gas producer in the Gulf of Mexico in the 1980s. It was one of the key players in the CentGas (Central Asia Gas Pipeline, Ltd.) consortium, an attempt to build the Trans-Afghanistan Pipeline to run from the Caspian area, through Afghanistan and probably Pakistan, to the Indian Ocean.
} 
Congress (Xinhua, August 3, 2005) . The failure of the CNOOC-Unocal bid, again, makes Beijing believe that, the world energy regime and energy market is always subject to the political influence from the major Western nations, and that the free market is not a reliable option to achieve energy security (Ye and Jiang, 2006).

Moreover, the Chinese NOCs' business activities have been firmly supported by the Chinese leadership's energy diplomacy to establish close relationships with oil and gas producing countries. The Chinese way of conducting energy diplomacy is also influenced by U.S. behavior and experience. In Beijing's view, each successive U.S. administration, for the sake of energy security, has constantly taken a firm grip of the principal energy producing regions so as to maintain its hegemonic status in a unipolar world (Gong, 2005).

Therefore, since the turn of the century, Chinese scholars and analysts has been suggesting that government should learn from Western experience and adopt 'energy diplomacy' to address China's energy issues (Wu, 2001; Qin, 2004; Chen, 2006; Zhao, 2007). For instance, Chen Huai, an energy expert at the Development Research Center of the State Council contended, "China cannot always go out to buy oil. The key is to tap existing technology and capital to exploit oil overseas" (Economic Information, Sep 21, 2004). China's former Foreign Minister Li Zhaoxin claimed in an interview, "Our diplomatic work should provide vigorous support to those efforts aiming to promote international energy cooperation" (21st Century Economics, Apirl 2, 2004). With the distrust on international energy market Beijing 
believes that special relationships with energy producers will guarantee the country reliable access to oil imports.

The diplomatic support from Beijing is practiced in several ways. First, it has been embodied in its efforts to cultivate special relations with energy-rich countries, providing foreign aid, project assistance or both. For example, China has established strategic partnerships with a group of major oil exporters including Saudi Arabia, Russia, Kazakhstan, Venezuela, Indonesia, Nigeria, etc (Calder, 2005; Tang, 2006). It can also take the form of negotiating free trade agreements (FTAs). For example, China has already signed FTAs with the Association of Southeast Asian (ASEAN) countries. FTA negotiation is under way with Australia the Gulf-Cooperation Countries (GCC). Moreover, it can also be providing economic assistance, such as debt relief. Between 2000 and 2002, China granted debt relief worth USD 1.26 billion (RMB 10.5 billion) to 32 African countries; in 2003, the country cancelled debts of African countries to China worth USD 750 million (Kong, 2005: 39). In 2006, Beijing called off more than USD 10 billion in debts of African countries (Chen, 2008a: 93).

Also, diplomatic support comes from the political leaders' personal involvement in facilitating energy deals with foreign countries. In recent years, Chinese leaders' visits to oil-producing countries in Central Asia, the Middle East, Africa, Latin America and Oceania have helped Chinese enterprises secure major deals. In 2002 the-then state president Jiang Zemin's visit to Libya paved the way for signing a cooperative agreement between CNPC and the Libya National Oil Company. In 
January 2004 China signed oil cooperation agreements with Egypt, Gabon, and Algeria respectively during $\mathrm{Hu}$ Jingtao's visits to those countries. His subsequent visit to South America also saw China's substantial investments in the energy sector, with Argentina alone attracting USD 20 billion from China (Chen, 2008a: 94). Moreover, the Chinese Ministry of Foreign Affairs has been assigned the task to assist in seeking any commercial opportunity, completing transactions and protecting China's overseas investments (Downs, 2004; Chen, 2006; Cheng, 2008).

\section{Summary}

With a comprehensive picture of China's energy situation, it is evident that oil is not as important as it is in most of the IWCs, and that oil import dependence is only a small share in China's energy demands. However, to China "energy security more accurately is oil security" (Feng, et al., 2004: 12). Current Chinese energy security thinking is overwhelmingly focusing on oil, invoking a disproportionate discourse on the security of China's oil supply. This is partly the consequence of China's long lasting fear of depending on foreign energy and more important, the adoption of oiloriented and supply-sided traditional Western energy security thinking. Thus, it seems that linkage of energy and security in China is the same as that of the West, and the nature of China's energy security issue is also an external energy supply issue. Consequently, the Chinese government also adopts external-looking policies to cope with the 'energy insecurity'. 
In reality, however, oil is merely one dimension of China's energy security concerns and not even the most important. Far less attention has been given to other energy issues and their economic security consequences. Actually, in the first decade of the 21st century, China has already experienced 'energy crises' which seriously threatened its economic security. These 'crises' are far beyond the scope of the traditional approach and caused heavy losses to the Chinese economy. 


\section{Chapter 5 Reassessing China's Energy Security}

\section{Introduction}

As we saw in Chapter Three, the traditional thinking of energy security is mainly built upon the high oil consumption and high oil import dependence situation in the IWCs. Experience of energy crises and other supply risks has established external oil supply as a key factor determining their economic performance. Thus, energy supply disruptions can cause serious deprivation of economic welfare, slowing down economic growth and threaten a country's comprehensive power and competiveness. As shown in the previous chapter, due to China's long lasting fear of depending on foreign energy, the Western experience has also been accepted as the empirical basis for most Chinese energy security analysis and invokes the outward-looking strategic and foreign policy response to China's 'energy insecurity'. However, a central question is: with the profound difference in the energy situation between the different economies, will the energy-economy nexus presented by the traditional thinking still hold valid?

In a broader security agenda, "states are exceedingly varied despite their fundamental similarities" (Buzan, 1991: 1469). The particular nature of security as a policy issue differs substantially from state to state. As an economic security issue, a country's energy security vulnerabilities and threats are determined by its energy situation and consequently the energy-economy nexus. Therefore, to examine this 
nexus and to reassess China's energy security situation is the central aim of this chapter.

By investigating the roles that oil and coal-based electric power play China's economy sectors, especially in industrial sector, I argue that, in contrast to the major IWCs, coal-based electric power is not only occupying a much larger share in China's energy consumption, but is also more important to China's economic growth at this stage. While the oil supply is stable but oil's share in China's energy consumption structure has been decreasing in recent years, China's limited power generation capacity and the problematic coal-electricity relationship have posed a serious threat to its economic growth. The cases of China's nation-wide power crises from 2003 to 2005 and again in 2008 and their economic consequences will be examined to support this argument.

\subsection{Industrial Sector and China's Economy}

Since the first five-year plan in 1953, following the development model of the Soviet Union, China has put industry (which is also referred to as 'Secondary Sector', 第二 产业) ${ }^{35}$, as the absolute priority in its comprehensive development. This strategy has been implemented consistently in the following five-year plans. As a result, one of the most striking characteristics of Chinese economy is the large share of industry output in its GDP (See Figure 14). In 2008, China's industry sector contributed more

\footnotetext{
${ }^{35}$ The Chinese definition of the primary sector of the economy mainly involves changing natural resources into primary products. Major businesses in this sector include agriculture, forestry, animal husbandry and fishery. The secondary sector of economy includes mining, manufacturing, production and supply of electricity, gas and water. Construction is also counted as secondary sector industry.
} 
than half of its total GDP, while the industry sectors in the United States and Japan only accounted for only about 22 percent of their respective GDPs (CIA, 2010). China's economic growth and the consequent energy demands have been mainly driven by the fast development of industry in the last decades. In 2007, industrial energy demand accounted for about 71 percent of total energy consumption (See Figure 15) (OECD/IEA, 2007a: 293; Leung, 2010: 936).

Economic growth is mainly driven by value-added production. Therefore, besides the shares in GDP, energy economists always investigate the relationship between certain economic sectors' added value and GDP growth rates to examine the correlations (Yang, 2008). Figure 14 shows changes in the share of each sector's contribution to China's GDP from 1990 to 2007. The share of the agricultural sector's contribution to GDP has dropped to below 5 percent since 1985 (NBS, 2009c). The pattern of the agricultural sector's growth rate has little correlation with that of national GDP. Meanwhile, the service sector, although its growth rate once increased rapidly around the turn of this century, has decreased significantly in recent years. Conversely, the share of the industrial sector has been growing quickly. Its levels of annual growth rates have also been very close to those of the national GDP. For example, the average annual growth rate of the value added in the industrial sector was about 10 percent between 1997 and 2005, which was about the same as China's GDP growth rate during the same period. This confirms that China's industrial sector was dominant in contributing to China's GDP over the past decades. This trend will continue if China maintains a high GDP growth rate and continues to favor investments in the industrial sector (Yang, 2008: 564; NBS, 2009). 
Figure 14 China's GDP Composition, 1990-2008 ${ }^{36}$

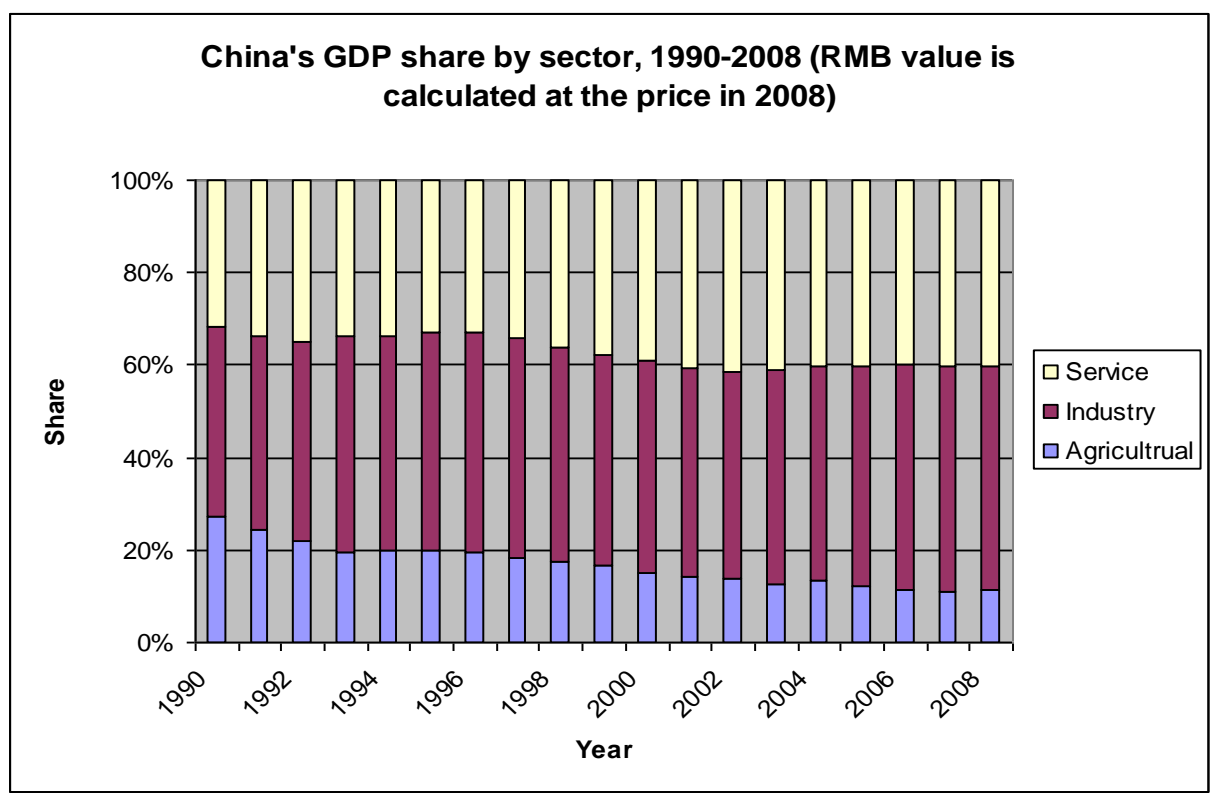

Figure 15 China's Primary Energy Consumption by Sectors, 1995-2008 ${ }^{37}$

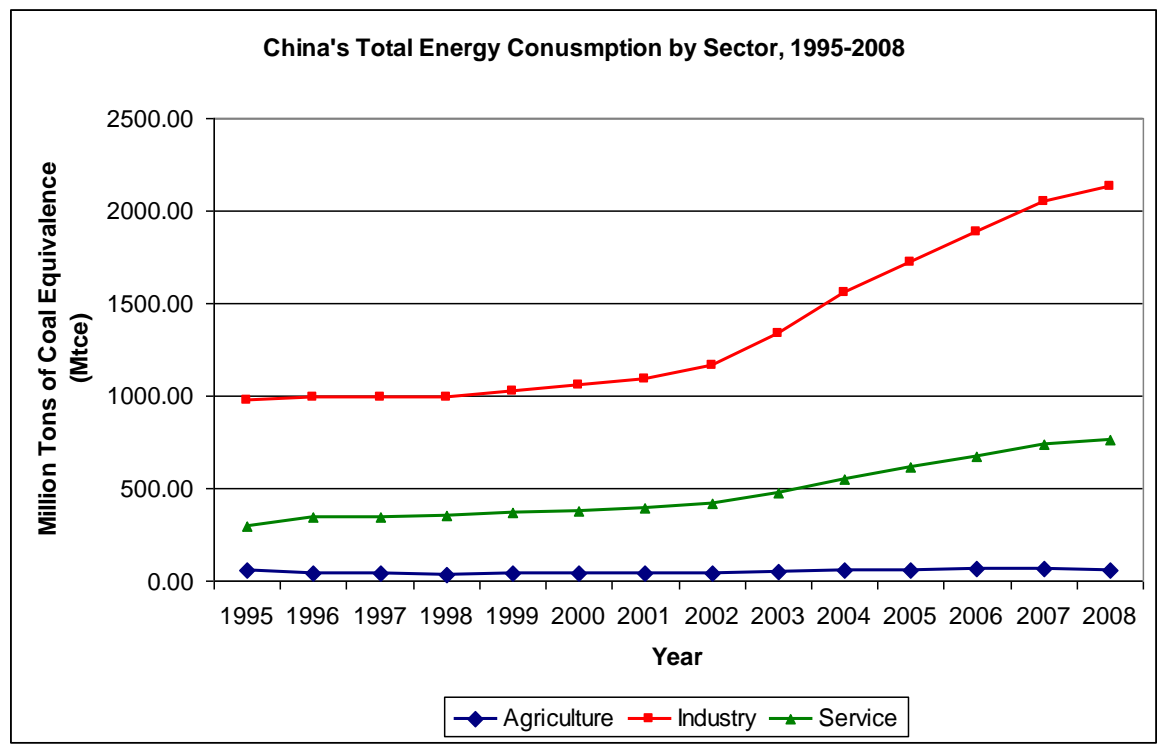

${ }^{36}$ Data Source: NBS, "2-12 Share of the Contributions of the Three Strata of Industry to the Increase of the GDP (表 1-12 三次产业贡献率)," in China Statistical Year Book 2009 (中国统计年鉴2009), ed. National Bureau of Statistics of China (中国国家统计局) (Beijing: China Statistics Publishing House, 2009c).

${ }^{37}$ NBS, "4-28 Consumption of the Total Energy and Its Main Varieties by Sector (表 4-28 分行业能 源消费总量) " in China Statistical Year Book 2009 (中国统计年鉴2009), ed. National Bureau of Statistics of China (中国国家统计局) (Beijing: China Statistics Publishing House, 2009e). 
As industrial output has grown strongly since the economic reforms in the late 1970s, especially since the turn of the century, China's surging energy demands have been mainly driven by the rapid development of industry in the last two decades (Qi, et al., 2007). Although the Asian Financial Crisis in 1997 brought huge negative impact on China's industrial exports and production, as a new economic cycle started in 2001 and China joined in WTO in the same year, industrial production picked up rapidly, which also drove industrial energy consumption (NBS, 2009; Zhao, et al., 2010). Industrial energy consumption reached 2131 Mtce in 2008, with its share in total energy consumption reached 73.1 percent (See Figure 15), which doubled that of 1990 and tripled the OECD average of 22 percent (NBS, 2009; OECD/IEA, 2007a: 291). Thus, no matter in terms of production output or energy demand, industry plays a vital role in China's economy. The following section will examine the roles that oil and coal-based electric power play in China's economy with a focus on the industrial sector. 


\subsection{The Role of Oil in China's Economy}

China's soaring oil consumption and increasing oil deficit have been well documented by various literatures. However, the role oil plays in China's economy is much less well understood. An analysis examining the role of oil in China's economy will undoubtedly help us understand the nature of China's energy security. Therefore, this section will investigate China's oil demands and use according to different economic sectors with a focus on industrial oil demands and use.

In general, China's oil demands by sector have changed significantly during the last decades, with a considerable reduction in industry and expansion in transport. The share of residential demands expanded, while agricultural demands shrank, and commercial demand remains stable. The overall share of oil in China's primary energy consumption has decreased in the last decade.

\subsubsection{Oil and Industrial Sector}

As stated, the heavy industry dominated industry development model is a key factor driving energy consumption (Qi, et al., 2007). From 1990 to 2007, the share of heavy industry in overall industrial outputs rose drastically from 50.6 percent to 70.5 percent (NBS, 2009c). Since heavy industry is much more energy intensive compared to light industry and the other two sectors (agriculture and service), the growth of industrial energy demands sped up. However, contrary to popular 
assumption, the rapid development of industry has not strengthened or promoted the role of oil in China's economy; Instead, the share of industrial oil demand declined from 59.2 percent in 1990 to 42.1 percent in 2007 , despite the share of industrial energy in China's total energy demand grew from 64.4 percent to 71.1 percent during the same time (See Figure 16) (NBS, 2009d; Leung, 2010: 936).

Figure 16 China's Primary Energy Consumption by Sector and Source, 1995-2007 $7^{38}$

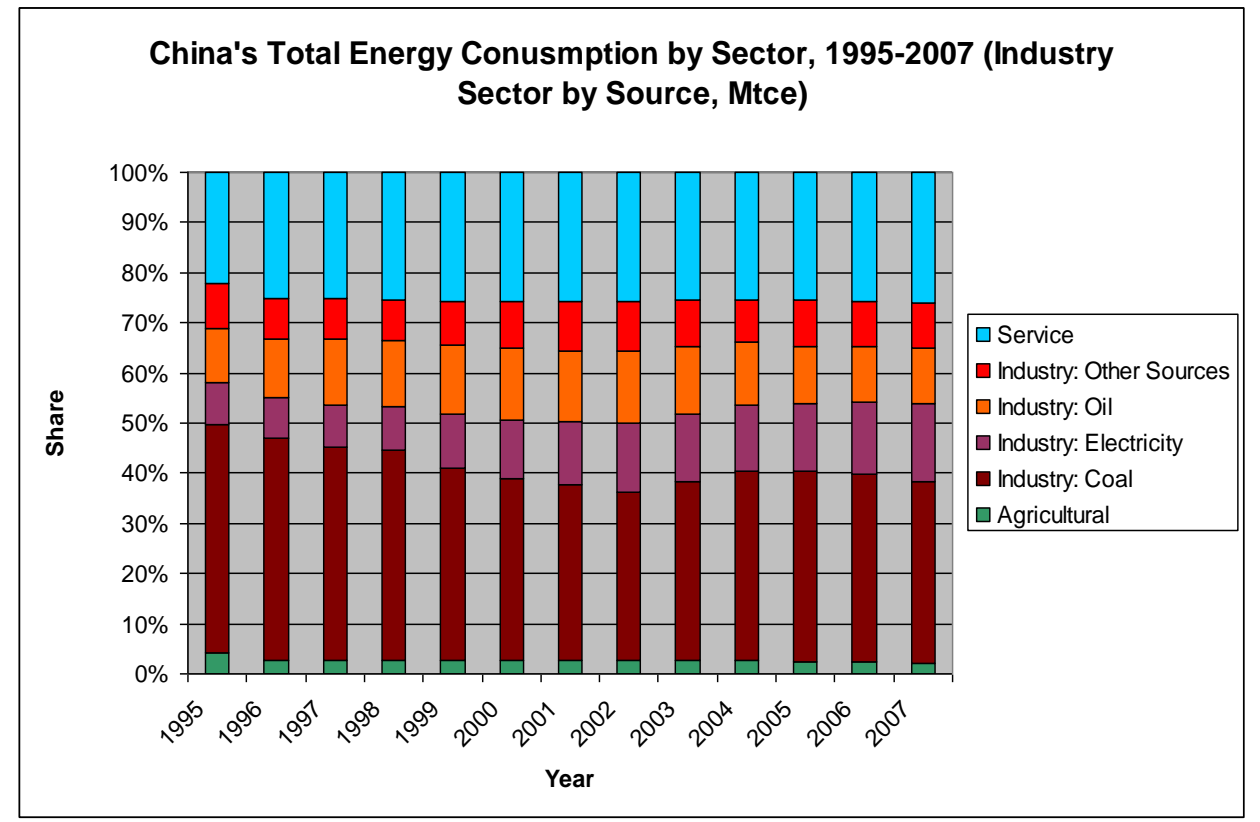

From 1990 to 2000, along with China's rapid economic growth, the share of oil consumption in the fuel mix of industry increased from 15.8 percent to 19.8 percent, despite some fluctuations brought by the 1997 Asian Financial Crises and the subsequent slow down of economic growth. However, in the new millennium, the

\footnotetext{
${ }^{38}$ Ibid. Also See Guy C.K. Leung, "China's Oil Use, 1990-2008," Energy Policy 2, no. 38 (2010). p 940.
} 
share of oil declined significantly (except for the period between 2001 and 2002), from the peak of 20.3 percent in 2002 to 15.2 percent in 2007 , which is even lower than its share in 1990 (See Table 1). The annual growth rate of industry's oil consumption has been slower than that of its overall energy consumption (NBS, 2009b).

Among the factors behind this situation, three of them are the most important. First, in spite of the rapid growth in overall energy use in some industrial sub-sectors, mainly textiles, mining and quarrying, utilities and other manufacturing industries, there have been absolute declines in their oil consumption, resulting in the dropping share of oil in their respective fuel mix (Leung, 2010: 937). Moreover, technology innovation and equipment upgrade in industry also contributed to the decline of energy demand. The ferrous metals industry, for example, has always been the largest energy consuming industry and expanded rapidly during 2003 and 2007 with an annual output growth rate of 18.1 percent. Nevertheless, its oil consumption fell by an average 6.2 percent per annum during the same period (OECD/IEA, 2007a: 291-296; NBS, 2009; Leung, 2010: 937).

Second, many energy-intensive industries encouraged by the Chinese government are not oil intensive in nature. Therefore, there is not a proportional increase in oil consumption with energy demands (Leung, 2010: 937). The non-metallic minerals industry, for example, is also a highly energy-intensive industry, and was the third largest energy consumer within Chinese industrial sector in 2005, consuming 14 percent of industrial energy demand. However, the sector's oil consumption 
accounted for only 7.5 percent in total industrial oil use during the same time (NBS, 2009).

Third, energy substitution also plays an important role. A large number of industrial plants have chosen electricity and to a lesser extent, natural gas, over oil as their fuel for producing heat for other industrial and residential sectors, because these sources can produce heat with greater efficiency and fewer pollutants (Leung, 2010: 940). The Chinese government's policy of limiting industrial oil consumption in the Tenth Five Year Plan (2001-2005) by setting up fuel oil consumption targets for the power, chemical, ferrous metal and non-metallic mineral industries also contributed greatly to the drop of the oil share and, consequently, the electrification of these sub-sectors (NDRC, 2001).

\subsubsection{Oil and Transport Sector}

Transport oil consumption is a different case compared with that of industrial sector. Globally research suggests that a country's economic growth is usually accompanied by an increase in transport energy consumption (Schäfer, 2005). China's transport energy demands grew 10.4 times, corresponding to the almost 11-fold GDP growth from 1978 to 2005 (Zhang, et al., 2007: 1). In spite of the amazing growth rate, transport still only accounts for a small share in China's total energy demand. China's total transport oil consumption rose from 40.1 Mtce in 1990 to 190.5 Mtce in 2007, with its share in total primary energy consumption increasing from 5.2 percent to 10.4 percent. This share accounts for half of the total oil consumption in 
China's primary energy demands, suggesting a high correlation between transport energy use and overall oil demands. In 2006, the share of transport in total energy consumption by sector was similar to that of India (10.3 percent), but significantly smaller than that of U.S. (41.3 percent) and the world average of 27.5 percent (OECD/IEA, 2009).

Transport is always considered as the most oil intensive sector, as there is no costeffective and efficient substitute for oil. The share of oil in the transport energy mix jumped from 58.6 percent in 1990 to 92.9 percent in 2007. Meanwhile, the share of coal declined from 38.6 percent to only 2.6 percent (Leung, 2010: 940). Transport's oil consumption skyrocketed from 16.4 to $121.3 \mathrm{mmt}$ during the same time, and its share in China's total oil consumption also rose 17.6 percent to 35.9 percent (NBS, 2009; Leung, 2010: 940). The surging oil consumption of China's transport sector can be attributed to two key factors: the rapid expansion of road transport and the burgeoning domestic air transport.

The IEA estimates that road transport accounted for over 80 percent of the overall growth in China's transport energy use during 1990-2005 (OECD/IEA, 2007a: 298). Behind the dramatic expansion of road transport were Chinese government's proactive highway network construction and the increasing ownership of automobiles. The Chinese government released a massive highway construction plan in 1998. The investment to highway construction in 1999 was RMB 120 billion, and increased rapidly to over RMB 400 billion since 2004. Today China's highway has increased from 10 thousand kilometers in 1999 to 53.6 thousand kilometers in 2007, 
which is only behind that of United States (Xinhua, Oct 17, 2008). Additionally, the Chinese government's 1994 Auto Policy designated the automobile industry as a pillar of economic development and officially encourages auto industry and private ownership of automobiles. The highway construction greatly facilitates the road transport, plus the government's pro-auto policy and the rising of per capita income, the number of private automobiles jumped from 5.5 million in 1990 to 43.6 million in 2007 (Leung, 2010: 941). Besides private passenger vehicles, freight vehicles also contribute a large share to the transport oil consumption. While total energy demand by cars increased 243.6 percent during 1990-2005, that by trucks has risen 244.4 percent. In 2005, trucks accounted for 39.7 percent of total road transport energy demand; cars, 30.8 percent; and buses and motorcycles, 29.5 percent (OECD/IEA, 2007a: 297).

The impressive development of domestic air transport in China also contributes to higher transport oil demand. From 1990 to 2007, the number of China's domestic air routes increased from 385 to 1216; domestic air passenger transport increased from 15,766 million persons-km to 217,331 million persons/kilogram; domestic air freight transport increased from 316 million tons $/ \mathrm{km}$ to 4157 million ton $/ \mathrm{km}$; and jet fuel consumption soared from 0.9 to $16.7 \mathrm{mmt}$ (NBS, 2009; Leung, 2010: 941).

\subsubsection{Oil and Agricultural, Residential and Commercial Sectors}

Agriculture, residential and commercial sectors collectively shared the about 22 percent of China's total oil consumption in 2007 (NBS, 2009d). Agriculture (also 
known as the primary sector) is traditionally neither a major oil user nor a large energy consumer in general (See Figure 16). Its oil demand is mainly driven by agricultural mechanization. In 2007, it accounted only for only 3.3 percent in China's total energy consumption, with oil representing 51.1 percent of total agriculture energy use (NBS, 2009d).

Residential oil consumption, mainly supplied by commercial energy sector in the urban areas, soared from 4.6 Mtce to 45.5 Mtce from 1990 to 2007, almost a ten-fold increase (NBS, 2009d). More than half of such oil use was for cooking and water heating (Leung, 2010: 940). Given that the rural population is still the majority in China, traditional biomass and coal use has remained stable in the past three decades and is unlikely to be substituted by oil. In 2007, the biomass energy consumed by residential sector was 260 Mtce, which was 30 percent more than commercial energy it consumed. The increasing use of liquefied petroleum gas (LPG) in urban area was the key driver of residential oil consumption growth. The urban energy use is increasingly 'modernized' with the growth of LPG, natural gas and electricity (NBS, 2009; Leung, 2010: 941-42).

There was also a significant change in the oil mix of the commercial sector in the last decade. The share of diesel, which is mainly consumed by vehicles as well to produce heat and motive power for a myriad of machines, soared from 28.6 percent to 48.5 percent; that of gasoline, virtually all of which is used by vehicles, declined from 52.3 percent to 43.2 percent; that of kerosene, used mainly by the Chinese military in the form of aviation fuel, dropped from 15.3 percent to 1.6 percent; and 
the combined share of LPG and fuel and crude oil increased slowly from 3.7 percent to 6.7 percent (Leung, 2010: 942). However, the oil demand of commercial sector only accounted for a very small percentage of total oil consumption, and these changes only slightly affected the total oil consumption.

In sum, although China's oil demands are increasing, they still only account for a small share in China's total primary energy consumption. More importantly, oil's contribution to China's major economic driving force - industry - is also quite limited. The demands for oil are mainly from the transport sector, which relatively contributes a modest share to China's GDP.

\subsection{The Role of Coal-based Electric Power in China's Economy}

As was noted in the previous chapter, coal has long been the backbone of China's energy system. Coal consumption has been on the rise in China over the last decade and has become increasingly important to China's economy. Coal use and the Chinese economy are connected by both the direct end use of coal in industry, and

more importantly, the industrial demand of coal-based electric power (See Figure 17). 
Figure 17 China's Primary Energy Consumption Structure by Sources and Sectors, $2008^{39}$

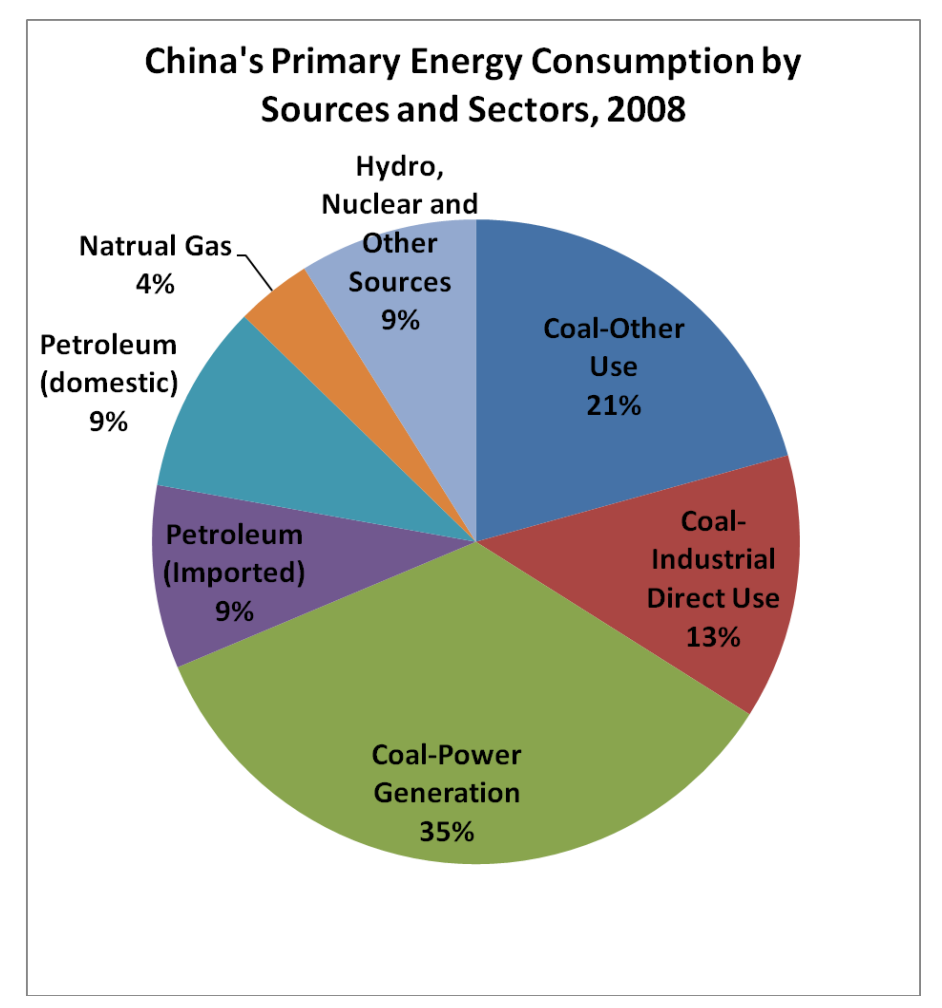

\subsubsection{Industrial Coal and Electric Power Demands}

Similar with its overall primary energy consumption structure, coal is also the dominant source of China's industrial energy demands (See Figure 16). Direct coal use accounts for half of total industrial energy consumption; the second most important is electricity, accounting for 21.6 percent industrial energy end use in 2008 (NBS, 2009d). Oil only accounted for 15.2 percent, and it has been decreasing

${ }^{39}$ NBS, "4-28 Consumption of the Total Energy and Its Main Varieties by Sector (表 4-28 分行业能 源消费总量) ". 
rapidly from a peak of 20.3 percent in 2002 (Leung, 2010: 936) (See Table 1 and Figure 16).

The industrial sector was responsible for as much as 95 percent of total coal consumption in China's economy in $2007 .{ }^{40}$ Industrial coal consumption is mainly concentrated in four sub-sectors, namely power and heat generation, metallurgy, chemical production and building materials (NBS, 2009; OECD/IEA, 2007a: 291296).

Power generation is the main consumer of coal, using about 50 percent in total coal consumption in 2008 (See Figure 17). The long-term trend of China's industrial coal consumption is a monotonic shift from direct end use to transformation, primarily through conventional thermal electricity generation (See Figure 18). Between 1990 and 2007, industrial end use of coal increased on an absolute basis, but its share of total coal consumption dropped from 34 percent to 19 percent. Over the same period, power generation increased from 26 percent to 50 percent (See Figure 18) (Aden, et al., 2009: 17).

The metallurgy industry mainly uses coking coal and fuel coal directly in daily production. The chemical industry demands lump anthracite for nitrogen fertiliser and fuel coal for heat supply. The building industry uses coal for cement and brick production (Manera, et al., 2008; OECD/IEA, 2007a). Thus, over the same period,

\footnotetext{
${ }^{40}$ This includes the coal used for industrial electricity generation.
} 
growth in coal use for power generation was followed by growth in coal use for coke production (18 percent), the end-use of coal for production of building materials (6 percent), delivered heating (residential district heating, 6 percent), and chemical production (3 percent) as the largest growth drivers (NBS, 2009: 19; Aden, et al., 2009).

Figure 18 The Share of Direct Coal Use and Power Generation of China's Coal Consumption,

$$
\text { 1990-2007 (Selected Years) }{ }^{41}
$$

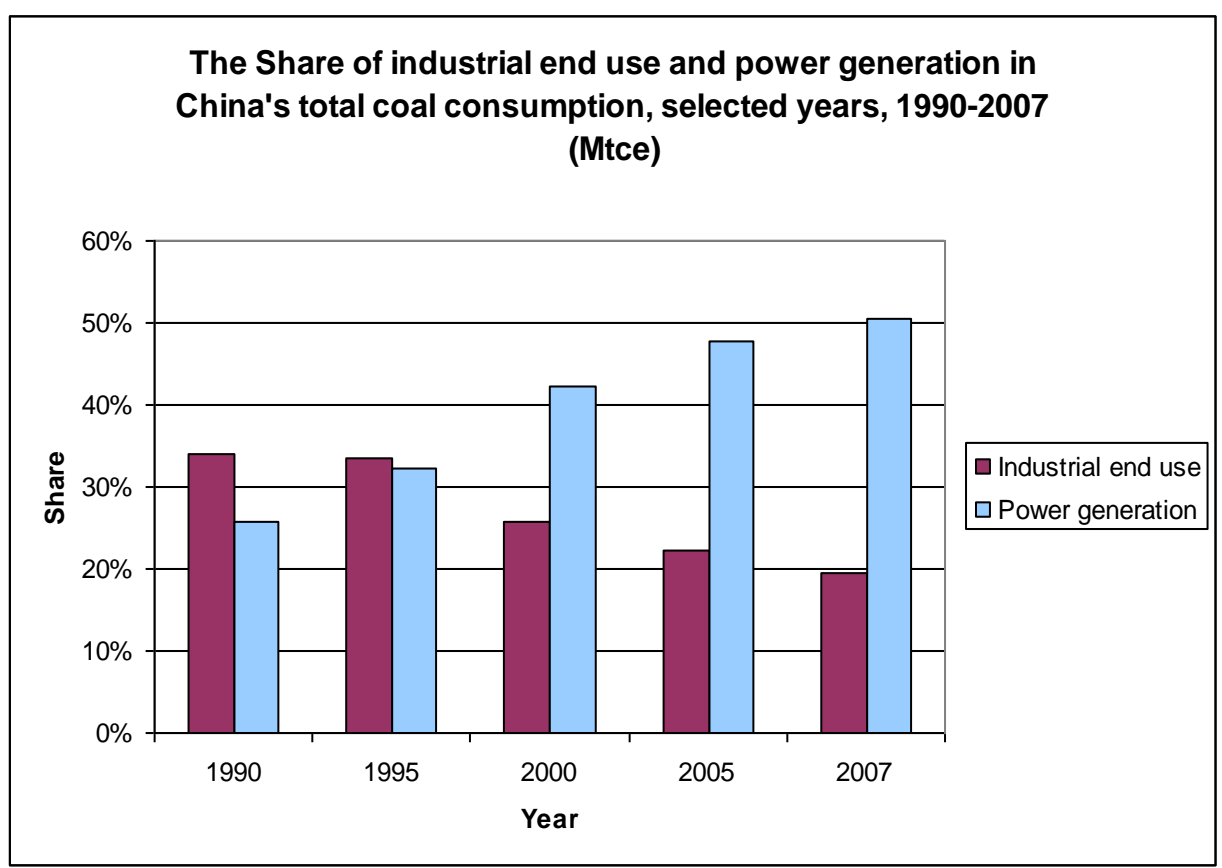

${ }^{41}$ Data Source: NBS, "6-9 Consumption of Energy by Sector (2007) (表 6-9 按行业分能源消费量 ，2007 年)," in China Statistical Year Book 2009 (中国统计年鉴2009), ed. National Bureau of Statistics of China (中国国家统计局) (Beijing: China Statistics Publishing House, 2009d), NBS, "428 Consumption of the Total Energy and Its Main Varieties by Sector (表 4-28 分行业能源消费总 量) ". 


\subsubsection{Coal-based Electric Power}

Electricity is the main form of secondary energy used around the world. In the countries which industry is the major driver of economic growth, electric power accounts for a high proportion of the total energy end use and is thus vital to a country's overall economic performance (NDRC, 2005). This is particularly true for China. Between 2000 and 2008 demand for electricity has increased quickly in step with strong economic growth and rapid development of industrial sector in particular. In 2006, 75.6 percent of China's electric power was consumed by the industrial sector. This figure rose to 79.1 percent in the first nine months of 2008 (Cui, 2008: 128).

Historically, the electric power industry was designated as a driving force of China's economic growth. In line with the rapid expansion of the Chinese economy in the last three decades, there has been an increasing demand for electricity. Today, China has the second largest electricity market in the world only behind the United States (NBS, 2009; EIA, 2010f).

In 2007, China had a total installed electricity generating capacity of $731 \mathrm{GW}$ and about 3,042 billion kWh of generation. Among the generating capacity, 76 percent (554 GW) came from coal (See Figure 19). This share is one of the highest in the world, only lower than that in countries such as Australia, South Africa and Poland (OECD/IEA, 2007a: 344). Thus, China's electric power system is predominantly coal-based, and this situation has been stable in the last three decades. Another 145 
GW capacity came from hydro, and $8850 \mathrm{MW}$ from nuclear (EIA, 2010f). Since 1995, thermal and hydropower sources have been consistently accounting for around 75 percent and 24 percent respectively of the total installed capacity, and about 81 percent and 18 percent of the total power generation, respectively (EIA, 2010f). Nuclear power generation remained at $2.1 \mathrm{GW}$ for several years and increased to 4.5 GW in 2002 and $6 \mathrm{GW}$ in 2004 (Lan, et al., 2007: 1468).

Figure 19 China's Electricity Generation by Fuel Sources, 1971-2007 $7^{42}$ China Electricity Generation by Fuel, 1971-2007

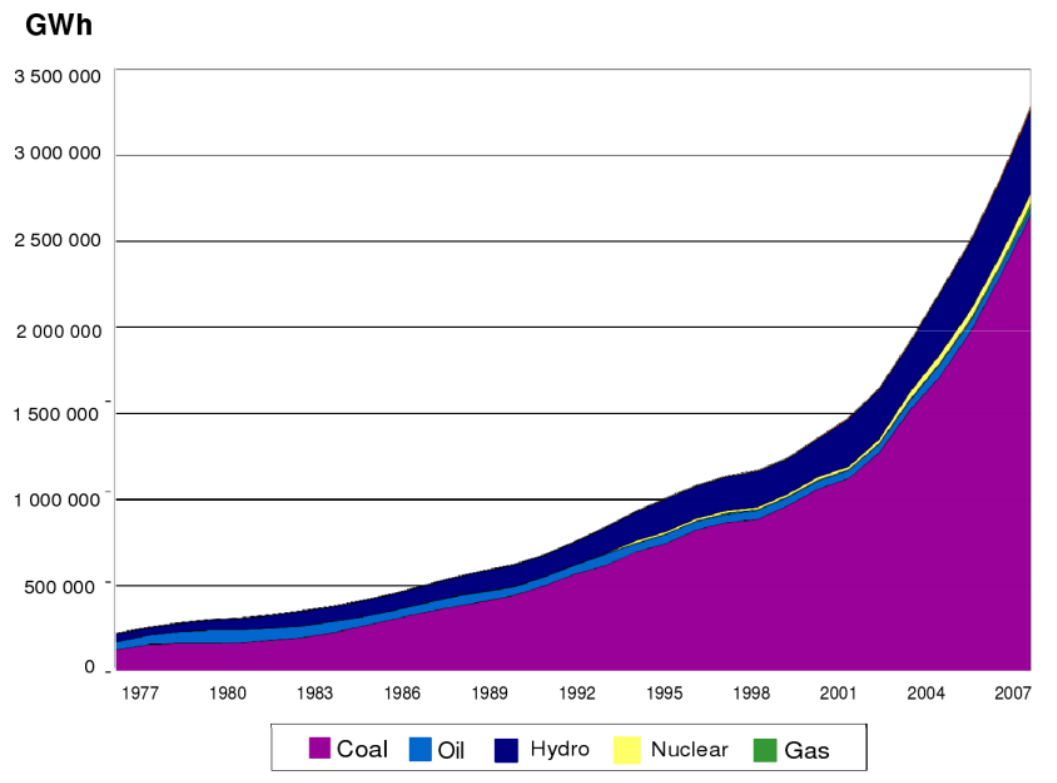

Although capacity building in the electricity production sector has increased rapidly in China, it remains the case that it still cannot meet the rising demand for electricity. Averaging 8.4 percent between 1990 and 2001, the annual growth rate of

${ }^{42}$ Data Source: EIA. "Electricity Generation by Fuel - People's Republic of China". U.S Energy Infomation Administration. Accessed in August, 2010, http://www.IEA.org/stats/index.asp. 
electricity consumption increased to 15.7 percent between 2002 and 2004 . Meanwhile, average GDP growth rate was 9.7 percent between 1990 and 2001 and 9.4 percent between 2002 and 2004 (Lan, et al., 2007: 1469; NBS, 2009). The electricity elasticity of GDP has changed significantly from 0.86 to 1.67 in the corresponding periods, showing strong positive correlation between electricity demand and economic growth. ${ }^{43}$ However, the average growth rate of power generation capacity was only 6 percent, which means electricity supply is trailing far behind demand (Lan, et al., 2007: 1469). As a result, large scale shortages of electricity supply have repeatedly occurred and seriously hampered the development of China's economy.

\subsubsection{The Vital Link: Electric Power and Economy}

Studies on the relationship between electric power consumption and economy growth began in the 1970s, and it was a part of empirical research on the energyeconomy nexus stimulated by the 1970s' energy crises. In John Kraft's seminal work, causality was found to run from GNP to primary energy consumption in the United States (Kraft and Kraft, 1978). Empirical studies were later extended to cover other industrial countries such as the United Kingdom, Germany, Italy, Canada, France and Japan (Yu and Choi, 1985; Erol and Yu, 1987; Hondroyiannis, et al.,

\footnotetext{
${ }^{43}$ In economics, elasticity is the ratio of the percent change in one variable to the percent change in another variable. It is a tool for measuring the responsiveness of a function to changes in parameters in a unit-less way. Here, the electricity elasticity of GDP means the ration of electricity demand growth rate to the GDP growth rate.
} 
2002). The models these surveys adopted mainly included the standard GrangerCausality (GC) and Error Correction Model (ECM). ${ }^{44}$

A general conclusion from these studies is that there is no consensus either on the existence or on the direction of causality between the variables. In other words, while some studies find causality running from economic growth to primary energy consumption, others find causality running from primary energy consumption to economic growth. Some studies found no causality between these variables. These conflicting results may arise due to the different data sets, countries' characteristics, variables or the different econometric methodologies that have been used. However, the conclusion derived from the electricity consumption and economic growth nexus for the country-specific studies show causality running from electricity consumption to economic growth in most of these studies (Ozturk, 2010: 347). Consequently, most energy economics studies conclude that electricity is a key limiting factor for economic growth (Ferguson, et al., 2000; Chen, et al., 2007; Narayan and Prasad, 2008). Thus, any shocks to electricity supply will have a negative impact on economic growth. Such studies in recent years have focused more on emerging Asian economies. In particular, there is a growing literature that examines the causality relationship between electricity consumption and economic growth in China.

\footnotetext{
${ }^{44}$ The Granger-Causality test is a widely used statistical hypothesis test for determining whether one time series is useful in forecasting another. See Granger, "Investigating Causal Relations by Econometric Models and Cross-Spectral Methods." An error correction model is a dynamical system with the characteristics that the deviation of the current state from its long-run relationship will be fed into its short-run dynamics. See Robert F Engle and Clive W J Granger, "Co-integration and Error Correction: Representation, Estimation, and Testing," Econometrica 55, no. 2 (1987).
} 
Alice Shiu and Pun-Lee-Lam first applied the ECM model to examine the causal relationship between electricity consumption and real GDP for China between 1971 and 2000. They detected that the unidirectional Granger-Causality from electricity consumption to real GDP for mainland China. In other words, an increase in electricity consumption would raise real GDP, but not the reverse (Shiu and Lam, 2004). Later, other scholars used co-integration theory ${ }^{45}$ to examine the causal relationship between electricity consumption and real GDP for China between 1978 and 2004. The results indicated that real GDP and electricity consumption for China are co-integrated and there is only unidirectional Granger-Causality running from electricity consumption to real GDP but not vice versa (Yuan, et al., 2007). Other studies further confirmed the causal relationship in recent years (He, et al., 2006; Ma, et al., 2010). Some scholars further argue that the relationship investigation should be base on the value added electricity consumption, such as industrial electricity consumption, rather than total electricity consumption that includes residential consumption (He, et al., 2007).

Therefore, it is well established by empirical research that electricity is a key limiting factor to economic growth and any shocks to the energy supply will have a negative impact on economic growth. For China, industrial production contributes a large share of GDP, the growth in industrial demand for electricity increases industrial output and which, in turn, raises the real GDP of China. This implies that growth in electricity consumption causes real GDP growth via industrial demand for

\footnotetext{
${ }^{45}$ Co-integration is a statistical property of times series variables. Two or more time series are cointegrated if they each share a common type of drift, that is, to a limited degree they share a certain type of behavior in terms of their long-term fluctuations. See Engle and Granger, "Co-integration and Error Correction: Representation, Estimation, and Testing."
} 
electricity. Thus, any disruptions to the electricity supply will adversely affect industrial output and thereby reduce real GDP growth. A key link between coalbased electric power supply and economic security is evident in China. This is the case that China witnessed between 2003 and 2005 when it suffered nationwide power shortages, and again in 2008.

\subsection{China's Real Energy Crises}

Historically there were widespread electricity shortages in the 1960s due to radical central planned economy development schemes and lagging capacity building. After the economic reforms in the late 1970s, there emerged electricity surpluses for the first time in 1997 (Zhang and Liu, 2006: 11). However, accelerating development of industrial sector and the growing pace of urbanization have challenged China's electricity supply again in the last decade (Cui, 2008). The first decade of this century has witnessed two waves of severe electricity shortages (“电荒”) in China. The nation-wide electric power shortages from 2003 to 2005 were without precedence. They caused such severe damage to China's economy that they was actually the first real energy crisis since China's emergence as a rising economy in the world.

The first wave of shortages occurred in 2003 and extended into 2005. At the peak of the shortages in 2004, a total of 24 provincial areas experienced power brownouts, 27 provincial electricity grids had to impose electricity quotas on both industrial and 
residential consumers (People's Daily, June 13, 2004). The State Grid ${ }^{46}$ alone had to cut power (拉闸限电) approximately 800, 000 times in 2004 (Zhu, 2006). The nation-wide power deficit amounted to $50 \mathrm{GW}$, about 17 percent of China's total installed capacity in 2004 (People's Daily, June 13, 2004; Yang, 2005). As one Chinese analyst commented, “China's electric power shortages has undoubtedly deteriorated from regional and seasonal ones to nation-wide and year-round shortages" (Wang, 2004: 2).

Among regions that suffered from the shortages, the most developed coastal provinces such as Zhejiang experienced continual power cuts and therefore bore the heaviest loss (Zhu, 2006). For instance, in the summer of 2003, all the cities and counties in the Province had to impose electricity use quotas, especially on the industrial plants, which only allowed industry plants to operate on certain days of the week (Wang, June 7, 2004). The province capital Hangzhou experienced no less than 10,000 power cuts, causing severe loss to the city's booming tourism industry (Zhu, 2006). Province wide, there were power cuts every day during the second half of 2003 minus only one day - 1st October, China's National Day. The 2003 nationwide $\mathrm{SARS}^{47}$ pandemics cost 0.3 percent of Zhejiang province's GDP in that year, while the power shortages costs at least 0.7 percent of Zhejiang's GDP in 2003 alone (Ding, et al., 2004: 46). In the first six months of 2004, the situation became even more severe. Blackouts and brownouts reduced about 48.2 million KWh electricity, which was 140 percent more than the reduced power in 2003. By the end of 2004,

\footnotetext{
${ }^{46}$ In 2002, the State Power Corporation, which enjoyed a monopoly position in Chinese power market, was split into two transmission companies and five power generation groups. State Grid Corporation of China (SGCC) and China Southern Power Grid (CSG) cover respectively about 80 percent and 20 percent of the national market.

${ }^{47}$ SARS is for Severe Acute Respiratory Syndromes.
} 
Zhejiang's electricity deficit amounted to $7.5 \mathrm{GW}$, causing approximately RMB 100 billion in losses, accounting for 8.6 percent of Zhejiang's GDP in 2004 (Northern Economy, 2005). Given that Zhejiang's GDP accounted for 7.3 percent of China's total GDP in the same year, the economic losses resulting from power shortages in the province alone caused a 0.63 percent loss to China's GDP in 2004 (NBS, 2009).

Moreover, the Yangtze Delta area, where the Beijing-Tianjin-Hebei economic zone is located and heavy industry is concentrated, suffered huge economic losses from power cuts as well. Central and western regions like Shanxi, Inner Mongolia also were also hit by large-scale brownouts (Zhu, 2006). In the largest coal producing province Shanxi, due to the power control policy of 'Residents First, Industry Second' (先生活, 后生产), industrial plants, including coal mining plants, had to cease the production to guarantee residential electricity supply, which caused at least RMB 18 billion in direct losses in 2004 (Zhu, 2006). According to Chinese energy economists' estimates, the nation-wide incremental power shortages from 2000 to 2005 caused at least RMB 1 trillion in losses, while China's total GDP in 2004 were only about RMB 16 trillion (Yang, 2005; Zhu, 2006; NBS, 2009).

The power shortages from 2003 to 2005 were China's first real energy crisis. They had an enormous negative impact on China's economy and on people's daily lives. Although the power deficit was alleviated by investment in new power stations in 2005, the wide gap between power supply and demand still exists. Seven provinces were hit by province-wide power cuts in that year, and the electricity deficit was around $25 \mathrm{GW}$ (Sun, et al., 2010). 
The power shortages stimulated a sharp rise in new power station construction across China. Most of the new capacity was made up of coal-fired plants, which is a key factor driving coal consumption. From 2002 to 2007, investment in generation capacity increased from RMB 74.7 billion to RMB 322.6 billion at an average annual increase of 28 percent (Wang, et al., 2009a: 2498). At the same time, investment in grids annually increased by 9 percent, from RMB 157.8 billion to RMB 245.1 billion (Wang, et al., 2009a: 2498). China brought two additional coalfired power plants to the power grid every week, and a total 361 plants were established between 2002 and 2006 (Kater, et al., 2007). Approximately 100 GW of new electric power were generated every year (Jiang, 2008), roughly the equivalent of Thailand and the UK's total capacities combined (Wasser, 2007). China had 380 million KW of installed power generating capacity by the end of 2003. By the end of 2007, this figure jumped to $713 \mathrm{GW}$. Chinese electricity output has jumped threefold, from 1910.6 GWh in 2003 to $3271.2 \mathrm{GWh}$ in 2007 (NBS, 2009).

However, it seems that the rapidly increasing generating capacity still can-not meet demand with an annual growth rate of 15 percent (Bradsher, 2010). For example, Beijing and Tianjin had a 1.1 million KW shortage of electricity in 2007 (Gao, 2008). What was even worse, China suffered another wave of power shortages at the beginning of 2008. Other than the problem of generating capacity, this time a natural disaster demonstrated the fragility and vulnerability of the China's energy transportation system and electric power grid system. 
In the first two months of 2008, a total of 19 provincial areas experienced power blackouts and brownouts similar to the ones in 2003-2005 (Wang, et al., 2009a: 2498). There were mainly caused by blizzards that lasted more than two weeks, from 10 January to the end of the month. The heavy snow and ice lasted for two weeks and damaged electricity grids and cut power supplies to the rail networks in central China that carry the bulk of coal to power stations. A total number of 36,700 power lines were cut off and 2,018 substations were deactivated. The provinces of Guangdong, Guangxi, Guizhou, Hunan, Anhui and Jiangsu had the worst power shortage problems, with more than 30 million people and thousands of industrial enterprises affected by blackouts or brownouts (Zhang, April 22, 2008). Shortages continued after coal supplies were disrupted to 17 provinces in February. The fuel stocks for power stations in southern China were operating with 16.5 million tons of fuel stock - a record low fuel stocks and were only enough to meet demand for seven days. In response, the government had to divert extra rail cars to move coal and sharply increased volumes shipped south by sea from the major northern port of Qinhuangdao (Zhang, April 22, 2008; Lague, 2008)

The two waves of power shortages demonstrated that in China the policy of ‘electricity supply must lead economic growth' (经济发展, 电力先行) (Zhu, 2000) should be maintained. In particular, the Granger-Causality running from electricity consumption to GDP indicates that electricity shortages even over the short-run will significantly constrain the regular pace of economic growth, which was evident from 2003-05, and again, in 2008 (Yuan, et al., 2007). 
To meet the demands for power in the coming decades, China will need to add nearly nine times as much electricity generation capacity as the United States will (Bradsher, 2010). Despite the enormous effort this will entail, the 2008 power shortage shows that increasing only power capacity does not suffice to ensure adequate power supply. Besides the generating capacity and coal transportation issues, construction and development of power grids in China also tends to be sluggish. Even when the seven individual grid systems function well, their interconnectedness is far from adequate, resulting in insufficient inter-grid electricity exchange capacity (Wang, et al., 2009a: 2498).

Additionally, reform of the coal and electricity sector markets is undoubtedly a much more profound institutional issue that is likely to constrain electric power development in the long run. China's coal and electricity industries traditional have a strong reliance on each other. In order to guarantee the fuel supply for electricity generation, the Chinese government made the policy of 'Coal-Electricity Interaction' (煤电联动) in 2004 (China News, Jan 7, 2010). Nevertheless, it is very difficult for these two sectors to form stable, reasonable, and transaction cost-saving relationships under the excessive intervention of government policies and instructions. Disputes over coal price and production-consumption quotas always take place between the two sectors (Wang, 2007c; China News, Jan 7, 2010). The coal market has been competitive since 1980 due to a dual track approach, but the coal sold to power sector was still tightly controlled by government-guided pricing. Unlike coal, entry to the electric power sector was gradually relaxed but generation and retailing tariffs are still strictly regulated. As energy demand and prices soared 
in the last decade, coal and electricity enterprises are all dissatisfied with the rule of price setting of coal sold to the electricity industry (Wang, 2007c: 4959). In 2008, an important reason that electricity shortages continued after the blizzards was that a large number of electric power plants struggled to secure increasingly costly coal (which was caused by the coal price reforms the year before) while other power plants shut down capacity rather than rack up losses by selling electricity at low rates (Bai and Hua, 2008). For all the recent discussion of energy security, potential major energy crisis is still looming on the horizon of China's energy economy development path.

\section{Summary}

In this chapter, by examining the roles that oil and coal-based electric power play in China's economy with a focus on China's industrial sector and, the case of China's power shortages, we can clearly see a strong energy-economic security link in China which is quite different to the scope of traditional approach in two ways.

First, with an energy consumption structure in which oil only accounts for a small share, oil-oriented energy security thinking can only address a quite limited part of China's comprehensive energy security issue. In contrast, coal and coal-based electric power do not only provide the bulk of China's energy needs, but are also more important to China's economic development by providing energy to industrial sectors, which is the main driving force of China's economic growth over the last several decades. 
Second, the emphasis of external energy supply in traditional thinking only puts about one tenth of China's primary energy demands into the scope of energy security. While China has not met troubles importing this 10 percent energy yet, the insecurity of coal-based electric power, which accounts for as high as 35 percent of China's total energy demands (See Figure 17, p109), have already brought two of energy crises and caused huge economic losses to China. Comparing with the major IWCs, China's unique energy consumption structure and energy-economy link means that the security of domestic energy supply might be even more an urgent issue than its foreign energy supply.

These findings suggest that, for China, traditional energy security thinking results in a very limited understanding of China's comprehensive energy security situation, drawing only a small part of the vulnerabilities it has and the threats it faces to the scholars and policy makers' attention and is therefore unhelpful to address China's comprehensive energy security issues. Instead, a different energy security approach which incorporates energy sectors other than oil and the security of domestic energy supply should be developed to guide the scholarly research and policy making. 


\section{Chapter 6 Conclusion}

This thesis has sought to demonstrate that, although they face profoundly different energy situations, the mainstream Chinese energy security thinking and policies are quite similar to those of Industrialized Western economies such as the United States, Japan and Western Europe. With detailed analysis in the preceding chapters, we saw that while the IWCs constructed their energy security thinking on a sense of common energy security vulnerability and common threats, China's energy security thinking had largely been influenced by energy 'self-reliance' doctrine and the Western approach. With a reassessment of China's energy situation, I argue that, the oil-oriented and external supply-sided traditional energy security thinking cannot comprehensively address China's energy security issues; the objects of energy security should be expanded to incorporate more energy sectors such as coal and electric power, and more attention must be paid to the security of domestic energy supply in such a large developing country like China. Therefore, paralleling the broadening of the security agenda in the 1970s, a broader energy security approach should be established in China to guide scholarly research and policy making.

This concluding chapter critically evaluates the necessity and feasibility of moving the scope of China's energy security beyond the traditional approach. A summary of the key findings from the previous chapters is offered. In the end, I point out a number of challenges that remain for future research on China's energy security. 


\subsection{The Spectrum of Energy and Security: From IWCs to China}

In contrast to the traditional national security thinking which was developed around military capabilities that views all states as essentially the same type of object, a broader security agenda or 'new security thinking' contends that security should cover a wider range of issues like economic concerns. It asserts that state differences outweigh their similarities as units. Specifically, "Insecurity reflects a combination of threats and vulnerabilities", and "only when one has a reasonable idea of both the nature of threats, and the vulnerabilities of the objects towards which they are directed, can one begin to make sense of national security as a policy problem" (Buzan, 1991: 112). Therefore, a core feature of the new security thinking is to recognize the diversity of security issues. Therefore, the conceptualization of security issues and the subsequent policy responses should vary substantially from country to country. Economic security was established on the basic linkage of economic competitiveness and the comprehensive power of a state. As an economic security issue, energy security could mean different things to a country with different combinations of energy vulnerabilities and threats. The analysis in Chapter Two clearly suggests that energy security cannot be seen as a unified and universally applicable concept. Therefore, states should construct their energy security thinking and make policies on the basis of their own material situations, namely the energyeconomy context, to address their respective energy security issues.

The notion of energy security was raised by the major IWCs during the 1970s' energy crises. As we saw in Chapter Three, the single most important feature in the 
major IWCs' energy situation is that the large share of imported fossil fuel, oil in particular, is a key factor determining their economic performance and overall competitiveness. The United States' economy has traditionally been heavily dependent on imported fossil fuel since WWII, especially oil and natural gas. Moreover, the origins of U.S. energy imports geographically concentrate in the Arab OPEC countries, many of which have had problematic relations with Washington and have suffered from unstable regional and domestic political situations. The staggering overall external energy dependence in Japan and the major Western European economies makes them very sensitive and vulnerable to any supply risks and market volatilities such as during the energy crises. In sum, it is the vulnerability of external dependence and threat of supply risks that have been at the center of Western energy security concerns. This has caused Western thinking about energy insecurity to see it in essence as an external supply issue. Accordingly, the traditional energy security concept was developed with a supply-sided and oiloriented focus. The continuing salience of the Carter Doctrine in the U.S. and the energy diplomacy of Japan and Western Europe in the last three decades demonstrate the persistence and influence of this concept on IWCs' energy security behavior.

As China has moved from being a minor and self-sufficient energy consumer to become the world's fastest-growing energy consumer in the early 1990s, the notion of energy security began to be introduced to the country. As China's economic performance has increasingly depended on energy supply, especially on fossil fuels, energy security has become a major national security concern to Beijing, stimulating 
debates about conceptualization and policy responses. Compared to the IWCs, China's energy situation is profoundly different. As the largest energy producer in the world, domestically produced energy provides about 93 percent of China's aggregate energy demands, a figure much higher than that of major IWCs (WDI, 2010). Moreover, the single most important feature of China's energy situation is the large share of coal consumption, accounting for as much as 70 percent in its primary energy consumption structure, indicating China remains a coal-based economy (See Figure 11, p65). Although oil and natural gas demands and imports has increased rapidly in absolute terms in the last decade, their share as a part of total primary energy consumption is still very modest, only accounting for 18 percent and 4 percent, respectively. China only needs to import 9 percent of its oil needs (See Figure 17, p109).

Although with a material situation in sharp contrast to that of major Western industrialized economies, China's energy security thinking, including its energy security concept and policies, are exceedingly similar with that of the West. To Beijing, "energy security more accurately is oil security" (Feng, et al., 2004: 12). I argue in Chapter Four that this is largely due to the Maoist heritage of the 'selfreliance' doctrine, and more importantly, the adoption of Western energy security ideas and behaviors by Beijing. Energy security policies such as strategically diversifying its energy imports by building pipelines and protecting key energy SLOCs; Building SPR in case of supply disruptions and market volatilities; promoting oversea energy investments and supporting commercial behavior with energy diplomacy. In general, China's energy security approach is overwhelmingly 
focused on oil (and to a lesser extent, natural gas) and issues around external energy supply. As a result, it seems that, despite the different energy situations, China's energy insecurity is also originating from the vulnerability of energy import dependence and external supply risks. However, should the 10 percent oil and gas imports really determine the main theme of China's energy security? Should China build its energy security thinking according to its material basis as is the case in the IWCs?

Such questions are answered in Chapter Five by a reassessment of China's energyeconomy context, the vulnerabilities it has and the threats it faces. With a detailed examination of the roles that oil and coal-based electric power play in China's economy, especially in the industrial sector, I find the link between coal-based electric power and China's economic development is much stronger than the oileconomy link at this stage. With the industrial sector contributing half of China's GDP and the surging electric power needed to maintain China's economic growth, the link of coal - electricity - GDP is well established in China (Shiu and Lam, 2004; He, et al., 2006; He, et al., 2007; Ma, et al., 2010). Additionally, the two waves of nation-wide electric power shortages in 2003-05 and 2008 demonstrated that the main energy security vulnerability that China has at this stage is mainly its limited power generation capacity and fragile power grids. Threats to China's energy supply are largely a domestic rather than an external issue. The threats to domestic supply range from the limited domestic energy transportation capability to problematic relations between coal and electric power sectors, but none of these vital energy security issues fall within of the scope if traditional approach. Therefore, the 
traditional approach can only capture and address a small part of China's comprehensive energy security challenges. In contrast to the assumption made by scholars like Buzan and in the case of IWCs' construction of their energy security concept, it is fair to say that Beijing did not have a "reasonable idea of both the nature of threats, and the vulnerabilities of the objects towards which they are directed" before developing its energy security concept and policies (Buzan, 1991: 112).

These findings strongly suggest that, for China, the traditional energy security approach offers only a very limited understanding of China's energy security situation and is thus unhelpful when it comes to comprehensively addressing China's energy security issues. Instead, broader energy security thinking which could incorporate more energy sectors such as coal based-electric power, and include issues like the security of domestic energy supply should be developed to guide scholarly research and policy making.

\subsection{Challenges to a Broader Energy Security Approach}

The biggest challenge to a broader energy security approach is probably the future development of China's energy situation. China is a country in economic transition as well as in "energy transition" (EIA, 2010f). International research suggests that structural change in the economy, from agriculture to industry to services, causes 
similar structural shifts in energy consumption. ${ }^{48}$ This structural change can be described as "initial rise, and later decline, of energy for shares used in industrial production; gradual rise of energy for services; steady growth of energy used directly by households, first for essential needs, later for discretionary uses; and, a trend closely connected to rising affluence, and increasingly share claimed by transportation'" (Smil, 2000: 34). It is undeniable that, albeit slowly for such a large country, China's energy situation is undergoing a similar structural transition, from low efficiency solid fuels to oil, gas, and electric power, from heavy industry to lighter and high-tech industry, from low motorization to rapid growth of the motor vehicle population (Adams and Shachmurove, 2008).

Accordingly, experts predict that continued rapid economic growth and industry upgrade in China will translate into a need to significantly expand the share of oil and gas in its energy consumption structure, and enhance energy imports. Although projections from different institutions vary in their predictions for China's energy demands in the next couple of decades, they agree that its aggregate energy consumption will continue to rise rapidly and the share of oil and gas will further increase (OECD/IEA, 2007a; EIA, 2010f). According to the International Energy Agency, China's primary energy demand is projected to climb from 1742 Mtoe in 2005 to 3819 Mtoe in 2030 (OECD/IEA, 2007a: 283). Such a large increase will bring serious supply pressures on both domestic and external energy supplies. Oil consumption is projected to increase from 7.3 million bbl/d (365 mmt per annum) to

\footnotetext{
${ }^{48}$ For instance, Andreas Schäfer illustrates such structural energy consumption shifts for 11 world regions from 1971 through 1998. See Andreas Schäfer, "Structural Change in Energy Use " Energy Policy 33, no. 4 (2005). Similar analysis can also be found in Nebojša Nakićenović, Arnulf Grübler, and Alan McDonald, eds., Global Energy: Perspectives (Cambridge, UK: Cambridge University Press, 1998).
} 
16.5 million $\mathrm{bbl} / \mathrm{d}$ in 2030 (825 $\mathrm{mmt}$ per annum), with its share in primary energy consumption rising from 10 percent to 20 percent. Oil import dependence could rise from 50 percent to 80 percent (13.1 million bbl/d, $655 \mathrm{mmt}$ ). China's oil imports in 2030 alone will be equal to the European Union's imports in 2030 (OECD/IEA, 2007a: 283-317). Thus, if the material basis will become increasingly similar to that of the IWCs, should China turn to a broader energy security approach?

The actual situation in the future will depend on technological progress, the development of an energy-intensive sector, and the adoption of appropriate policies now and in the immediate to near future. Increasing fossil fuel imports can be offset by increasing domestic energy production or by improvements in the efficiency of use, particularly in the production of electric power (Adams and Shachmurove, 2008: 1263). A variety of projections of China's future energy demands agree that, in the foreseeable future, coal will remain the dominant fuel in China's energy mix, and coal-based electricity generation will continue to play a key role in driving China's economic growth (Cui, 2008). According to the most authoritative IEA projection, coal consumption is expected to grow slightly in the near term before slowly falling back to 63 percent by 2030 (OECD/IEA, 2007a: 288). The electric power sector will remain the main coal user through to 2030, accounting for more than two-thirds of the incremental coal demand. After 2010, coal use for coal-liquids $(\mathrm{CTL})^{49}$ plants is expected to rise rapidly, reaching 72 Mtoe in 2030, compensating a significant amount of China's oil deficit (OECD/IEA, 2007a: 288). Electricity supply will be continually under heavy pressure. In order to sustain continuing

\footnotetext{
${ }^{49}$ The Chinese government is actively promoting the development of a large coal-to-liquids industry. Subsidised by Chinese government, Shenhua Group（神华集团）, which is the world's largest coal company, has completed the construction of the country's first CTL plant in 2008.
} 
economic growth, power generation is projected to increase by 4.9 percent per year, more than tripling by 2030 (OECD/IEA, 2007a: 344). At 8472 TWh, China's generation in 2030 will be comparable to the current level of production in OECD North America and Europe combined (OECD/IEA, 2007a: 344).

Therefore, in the foreseeable future, China will undoubtedly still rely on domestic energy production to meet the majority of its aggregate energy demands. As the largest energy producer in the world, China is unlikely to transit to a high external energy dependence economy such as Japan and Western Europe. As long as this situation persists in China, it is necessary to develop a broader energy security approach to address China's energy security comprehensively.

As Professor Jin Canrong, an influential Chinese IR scholar commented in a lecture at Victoria University of Wellington in July 2010, as the second largest economy and a leading nation in the world, "China changes the world by changing itself" (Jin, July, 2010). Indeed, in July 2010, the International Energy Agency announced that, according to their latest statistics, China overtook the United States to become the world's largest energy consumer (IEA, 20 July, 2010). Although Beijing questioned this conclusion, citing the different statistics techniques used by China and the IEA (Hook, July 20, 2010; Xinhua, July 22, 2010), the fact that China has become a key actor in the global energy situation is undeniable. As the largest energy producer and possibly the largest energy consumer in the world, China should address its energy security issues comprehensively under a broader approach, which is not only crucial to China's future but also extremely important to the rest of the world. 


\section{Bibliography}

21st Century Economics. Apirl 2, 2004. "Breaking through the Besiege of Russia, US, Japan and India: The Five-Circle Energy Diplomacy of China (打破俄、美、日、印的包 围圈, 中国能源的五环外交)." 21st Century Business Report (21 世纪经济报道).

Adams, F. Gerard, and Yochanan Shachmurove. 2008. "Modeling and Forecasting Energy Consumption in China: Implications for Chinese Energy Demand and Imports in 2020." Energy Economics 30, no. 3: 1263-1278.

Aden, Nathaniel, David Fridley, and Nina Zheng. 2009. China's Coal: Demand, Constraints, and Externalities. Ernest Orlando Lawrence Berkeley National Laboratory. 2009.

AGA. 2010. "Snapshot of U.S. Natural Gas Consumption (2008)". American Gas Association, http://www.aga.org.

Aguiar-Conraria, Luis, and Yi Wen. 2007. "Understanding the Large Negative Impact of Oil Shocks." Journal of Money, Credit and Banking 39, no. 4: 925-944.

Amuti, Anwar, and Shengwang Zhang. (安尼瓦尔・阿木提, 张胜旺). 2003. Oil and National Security (石油与国家安全). Urumqi: Xingjiang People's Publish House (新 疆人民出版社), 2003.

Anderlini, Jamil. 2010. Financial Times August 23, 2010 "China's Monster Traffic Jam: A Sign of Things to Come." http://blogs.ft.com/beyond-brics/2010/08/23/chinasmonster-traffic-jam-a-sign-of-things-to-come/.

Bahgat, Gawdat. 2001. "United States Energy Security." The Journal of Social, Political, and Economic Studies 26, no. 3: 515-542.

Bai, Jim, and Judy Hua. 2008. Thomson Reuters Jan 23, 2008 "Record Power Shortage Hits China." http://www.reuters.com/article/idUSPEK8411420080123.

Baldwin, D. A. 1995. "Security Studies and the End of the Cold War." World Politics 48, no. 2: $117-141$.

Barry, John M. 1992. "Administration's Annual Economic Report Presents Lower Expectations." Washington Post, A14.

Berman, Wayne, Richard J. Kessler, and Eugenie Maechling. 1982. "The Roots of the Energy Crisis." In The Critical Link: Energy and National Security in the 1980s, edited by Charles K. Ebinger, 1-38. Cambridge, Massachusetts: Balllinger Publishing Company.

Bielecki, J. 2002. "Energy Security: Is the Wolf at the Door?" The Quarterly Review of Economics and Finance 42, no. 2: 235-250. 
Bock, P. G., and Morton Berkowitz. 1966. "The Emerging Field of National Security." World Politics 19, no. 1: 122-136.

Bohi, Douglas R., Michael A. Toman, and Margaret A. Walls. 1996. The Economics of Energy Security. Boston, Massachusetts: Kluwer Academic Publishers, 1996.

Booth, K. 1991. "Security and Emancipation." Review of International Studies 17, no. 4: 313326.

Boulding, Kenneth E. 1973. "The Economics of Energy." Annals of the American Academy of Political and Social Science 410, no. The Energy Crisis: Reality or Myth: 120-126.

BP. 2008. BP Statistical Review of World Energy. BP. London, 2008.

Bradsher, Keith. 2010. The New York Times (Website). Jan 30, 2010. "China Leading Global Race to Make Clean "Cnergy." http://www.nytimes.com/2010/01/31/business/energyenvironment/31renew.html? $\mathrm{r}=1$.

Bullock, Todd, and Katie Xiao. 2005. Congress Cites Security Concerns over Chinese Bid for Unocal. U.S. Department of State Official Website. Washington. http://www.america.gov/.

Burbidge, John, and Alan Harrison. 1984. "Testing for the Effects of Oil-Price Rises Using Vector Autoregressions." International Economic Review 25, no. 2: 459-484.

Buzan, Barry. 1991. People, States and Fear. 2 ed. Boulder, Colorado: Lynne Rienner Publishers, 1991.

Cable, Vincent. 1995. "What Is International Economic Security?" International Affairs 71, no. 2: 305-324.

Calabrese, John. 2002. "In the Shadow of Uncertainty: Japan's Energy Security and Foreign Policy." Pacific and Asian Journal of Energy 12, no. 1: 81-101.

Calder, Kent E. 2005. China's Energy and Its Geopolitical Implications. The Edwin O. Reischauer Center for Far East Asian Studies. Washington D.C., 2005.

Cao, Xing. (曹新). 2007. "The Trend of International Oil Price and China's Oil Security (国 际油价变动趋势和中国石油安全问题研究)." Review of Economic Research (经济 研究参考) 2007, no. 60: 4-10.

Carter, Jimmy. 1980. "The State of the Union Address Delivered before a Joint Session of the Congress". The American Presidency Project Website, Aug 2010, http://www.presidency.ucsb.edu/ws/index.php?pid=33079.

CCS. 2007. China Customs Statistics Online. "The First Phase of SPR Has Been Put into Use (国家战略石油储备基地一期工程投入使用杭州口岸原油进口地位进一步增强)." http://www.chinacustomsstat.com/. 
Chandler, Clay. "Can China Keep the Lights On?" Fortune, Febuary, 23, 2004.

Chang, Felix K. 2001. "Chinese Energy and Asian Security." Orbis 45, no. 2: 211-240.

Chen, Dao Kuo. (陈道阔). 1994. A Chinese Great Battle for Oil (中国石油大会战). Beijing: Eight-One Publish House (八一出版社), 1994.

Chen, Hui. (陈惠). 2006. "China's Energy Strategy and Energy Diplomacy in the Context of Economic Globalisation (经济全球化背景下中国的国际能源战略和能源外交)." China Report (中国报道) 2006, no. 5: 28-30.

Chen, Shaofeng. 2008a. "Motivations Behind China's Foreign Oil Quest: A Perspective from the Chinese Government and the Oil Companies." Journal of Chinese Political Science 13, no. 1: 79-104.

Chen, Sheng-Tung, Hsiao-I Kuo, and Chi-Chung Chen. 2007. "The Relationship between Gdp and Electricity Consumption in 10 Asian Countries." Energy Policy 35, no. 4: 2611-2621.

Chen, Yangyong. (陈扬勇). 2008. People's Daily Online (人民网). November 10, 2008. "The Forming and Significance of Jiang Zemin's 'Going out' Strategy (江泽民 “走出 去”战略的形成及 其重要意义）" http://finance.people.com.cn/GB/8215/126457/8313172.html.

Cheng, Joseph Y.S. 2008. "A Chinese View of China's Energy Security." Journal of Contemporary China 17, no. 55: 297-317.

Chester, Lynne. 2009. "Conceptualising Energy Security and Making Explicit Its Polysemic Nature." Energy Policy 38, no. 2: 887-895.

China Daily. Jan 7, 2004. China Daily Online (in English). "China to Increase Oil-Supply Security." http://china.org.cn/archive/2004-01/07/content 1084151.htm.

China News. (http://www.chinanews.com/ny/news/2010/01-07/2058947.shtml). Jan 7, 2010. "The First Year of 'Coal-Electricity Interreaction' Reform, How to Deal with the Quarrel between Coal and Electric Sectors? (直考中国煤电联动改革第一年 煤电之 争怎样化解)". China News (中国新闻网),

Chinese Central Gov. 2009. The Central Goverment of People's Republic of China Online ( 中国中央政府网站). Januray 23, 2009. "Our Oil Consumption Accelarating in 2008 (2008 年我国石油消费先热后冷 全年保持较 快 增长)." http://www.gov.cn/jrzg/2009-01/23/content 1214200.htm.

Choucri, Nazli, and Vincent Ferraro. 1976. "Economic Effects of the Petroleum Cartel: Prices, Payments, and Proposals." In International Politics of Energy Interdependence: The Case of Petroleum. Lexington, Massachusetts: Lexington Books. 
CIA. 2010. "The World Fact Book." U.S. Central Intelligence Agency, https://www.cia.gov/library/publications/the-world-factbook/fields/2012.html

Cohen, Ariel. 2007. "Europe's Strategic Dependence on Russian Energy." The Heritage Foundation, http://www.heritage.org/research/reports/2007/11/europes-strategicdependence-on-russian-energy.

Constantin, Christian. 2005. "China's Conception of Energy Security: Sources and International Impacts." Working Paper NO. 43, University of British Columbia. http://www.ieem.org.mo/documents/mes/04-06/houweling/Chinaenergysecurity.pdf.

Correljé, Aad, and Coby van der Linde. 2006. "Energy Supply Security and Geopolitics: A European Perspective." Energy Policy 34, no. 5: 532-543.

CPCI. 2003. "American Strategic Petroleum Reserve (美国的战略石油储备)." China Petroleum and Chemical Industries (中国石油和化工), no. 3: 64-65.

Cui, Minxuan. (崔民选), 2008. ed.^eds. Annual Report on China's Energy Development 2008 (中国能源发展报告). Beijing: China Social Science Academic Press (中国社会科学 出版社), 2008.

Deese, David A. 1980. "Energy: Economics, Politics and Security." International Security 4, no. 3: 140.

Ding, Huikai, Wen Jin, and Jiying Jin. (丁会凯, 金斐, 金季英). 2004. "The Reason of Electrical Power Shortage and the Countermeasure Analysis (电荒产生原因及应对 策略分析)." Journal of Shanghai Institute \& Electric Power (上海电力学院院报) 20, no. 4: 45-48.

Ding, Yuanyuan. 2008. "The Party, the Oil Companies, and Energy Security: Who Determines Chinese Policy?", MA Dissertation, Georgia State University, 2008.

Downs, Erica S. 2004. "The Chinese Energy Security Debate." The China Quarterly 177: 2141.

Downs, Erica S. 2006. The Energy Security Series: China. The Brookings Institution. Washington D.C., 2006.

Ebinger, Charles K. 1982. ed.^eds. The Critical Link: Energy and National Security in the 1980s. Cambridge, Massachusetts: Balllinger Publishing Company, 1982.

Economic Information. Sep 21, 2004. "Chinese Oil Firms 'Go out' to Resolve the Oil Predicament (中国石油企业海外拓展, “走出去” 破解石油困局)." Economic Information (经济参考报).

EIA. 2010f. "Country Analysis Briefs: China". U.S. Energy Information Administration, Accessed in August, 2010, http://www.eia.doe.gov. 
EIA. 2010g. "Electricity Generation by Fuel - People's Republic of China". U.S Energy Infomation Administration, Accessed in August, 2010, http://www.IEA.org/stats/index.asp.

EIA. 2010a. "Historical Energy Data". U.S. Energy Information Administration, Accessed in August, 2010, http://www.eia.doe.gov/emeu/aer/eh/eh.html.

EIA. 2010. "International Energy Statistics". U.S Energy Infomation Administration, Accessed in August, 2010, http://www.eia.doe.gov.

EIA. 2010e. "U.S. Coal Consumption by End-Use Sector ". U.S Energy Infomation Administration, Accessed in 2010, http://www.eia.doe.gov/cneaf/coal/quarterly/html/t32p01p1.html.

EIA. 2010d. "U.S. Natural Gas Imports by Country ". U.S. Energy Infomation Administration, Accessed in August, 2010, http://www.eia.gov.

EIA. 2010b. "U.S. primary energy overview 1949-2009". U.S Energy Infomation Administration, Accessed in 2010, http://www.eia.doe.gov/aer/txt/ptb0101.html.

Engle, Robert F, and Clive W J Granger. 1987. "Co-Integration and Error Correction: Representation, Estimation, and Testing." Econometrica 55, no. 2: 251-276.

Erol, Umit, and Eden S. H. Yu. 1987. "On the Causal Relationship between Energy and Income for Industrializing Countries." The Journal of Energy and Development 13, no. 1: 113-122.

Feng, Fei (冯飞), Zhou Fengqi (周凤起), and Wang Qingyi (王庆一). 2004. Report on China ，s Energy Development Strategy and Policy (中国能源发展战略与政策研究报告). Project team of Report on China's Energy Development Strategy and Policy ( “中国 能源发展战略与政策研究报告”课题组). Vol. 83 Jinji Cankao Yanjiu, 2004. (载《 经济参考研究》2004 年 83 期), 2004.

Feng, Yujun. (冯玉军). 2004. "The International Petroleum Strategic Situation and the SinoRussia Energy Cooperation Prospects (国际石油战略格局与中俄能源合作前景)." Contemporary International Relations (现代国际关系) 2004, no. 5: 23-28.

Ferguson, Ross, William Wilkinson, and Robert Hill. 2000. "Electricity Use and Economic Development." Energy Policy 28, no. 13: 923-934.

Fried, Edward R., and Philip H. Trezise. 1993. Oil Security: Retrospect and Prospect. Washington, D.C.: Brookings Institution, 1993.

Fu, Yong. (傅勇). 2009. "The Combination of Energy Elements and Sino-US/Sino-Russia Energy Cooperation (能源要素组合与中美一中俄能源战略合作)." Contemporary International Relations (现代国际关系) 2009, no. 12: 40-47. 
Fu, Zhengji. (傅政骥). 1992. "American Strategic Petroleum Reserve (美国的战略石油储备 )." World Petroleum Economics (世界石油经济), no. 4.

Gao, Jian. (高健). 2005. "How to Guarantee Oil Security in a Time of High Oil Price (高油 价时代如何保证石油安全)." China Reform (中国改革) 2005, no. 12: 50-51.

Gao, Yongyu. 2008. "Overseas Electricity Purchase of State Grid to Relief of Electricity Shortage and Fastening Development of Sino-Korea Yalu Jiang River." The First Finance Daily.

Gelb, Leslie H. 2010. "GDP Now Matters More Than Force: A U.S. Foreign Policy for the Age of Economic Power." Foreign Affairs 89, no. 6: 35-36.

Gilpin, Robert. 1977. "Economic Interdependence and National Security in Historical Perspective." In Economic Issues and National Security, edited by Klaus Knorr and Frank N. Trager, 330. Lawrence, Kansas: Allen Press, Inc.

Gisser, Micha, and Thomas H Goodwin. 1986. "Crude Oil and the Macroeconomy: Tests of Some Popular Notions." Journal of Money, Credit and Banking 18, no. 1: 95-103.

Gong, Zhongming. (龚钟明). 2005. "To Probe into China's Future Energy Strategy in Light of World Energy Developing Trends (从世界能源发展趋势探索未来中国能源战略 )." Energy Policy Research (能源政策研究) 2005, no. 3: 33-36.

Granger, C W J. 1969. "Investigating Causal Relations by Econometric Models and CrossSpectral Methods." Econometrica 37, no. 3: 424-438.

Gu, Zuhua. (顾祖华). 2004. "China Must Have Powerful Navy to Ensure the Security of Energy Sea Lanes (维护海上石油安全须有强大海上编队)." Contemporary Navy ( 当代海军) 2004, no. 8 .

Guan, Qingyou, and He Fan. (管清友, 何帆). 2007. "China's Energy Security and International Energy Cooperation (中国的能源安全与国际合作)." World Economics and Politics (世界经济与政治) 2007, no. 11.

Hamilton, James. 1985. "Historical Causes of Postwar Oil Shocks and Recessions." Journal of Political Economy 6, no. 1: 97-116.

Hamilton, James. 1983. "Oil and the Macroeconomy since World War II." Journal of Political Economy 91, no. 2: 228-248.

Hamilton, James, and Ana Maria Herrera. 2004. "Oil Shocks and Aggregate Macroeconomic Behavior: The Role of Monetary Policy." Journal of Money, Credit, and Banking 36, no. 2: 265-286.

He, Yongxin, Wei Wang, Qun He, and Dawei ; Wang. 2006. "Research on Relationship between Cycles of Electric Power and the Economy Growth in China Based on 
Maximum Entropy Method." In 2006 International Conference on Management Science and Engineering, 5-7 Oct, 2006. Lille: IEEE.

He, Yongxiu, jiajia Wei, Dezhi Li, and Liangqi Wu. 2007. "Study of the Relationship between Electricity and National Economy Growth in China from the Angle of Production." In International Conference on Wireless Communications, Networking and Mobile Computing, 21-25 Sept. 2007. Shanghai: IEEE.

Hondroyiannis, George, Sarantis Lolos, and Evangelia Papapetrou. 2002. "Energy Consumption and Economic Growth: Assessing the Evidence from Greece." Energy Economics 24, no. 4: 319-336.

Hook, Leslie. July 20, 2010. "China Denies IEA Claim on Energy Use". Financial Times Website, $\quad$ http://www.ft.com/cms/s/0/6ca47fa2-9402-11df-83ad00144feab49a.html\#axzz1C2bvokgQ.

Hubbard, R. Glenn. 1986. "Supply Shocks and Price Adjustment in the World Oil Market." The Quarterly Journal of Economics 101, no. 1: 85-102.

Hunt, Lester C., and Yasushi Ninomiya. 2005. "Primary Energy Demand in Japan: An Empirical Analysis of Long-Term Trends and Future Co2 Emissions." Energy Policy 33, no. 11: 1409-1424.

Huntington, Samuel P. 1999. "The Loney Superpower." Foreign Affairs 78, no. 2: 35-49.

Ian Barbour, Harvey Brooks, Sanford Lakoff, and John Opie. 1982. Energy and American Values, New York: Praeger Publishers, 1982.

IEA. 20 July, 2010. "China Overtakes the United States to Become World's Largest Energy Consumer ". International Energy Agency, http://www.IEA.org/index_info.asp?id=1479.

Ikenberry, G. John. 1986. "The Irony of State Strength: Comparative Responses to the Oil Shocks in the 1970s." International Organization 40, no. 1: 105-137.

Inoguchi, Takashi. 1993. Japan's Foreign Policy in an Era of Global Change. New York: St. Martin's Press, 1993.

Jaffe, Amy Myers, and Ronald Soligo. 2008. "Militarization of Energy: Geopolitical Threats to the Global Energy System." The Global Energy Market: Comprehensive Strategies to Meet Geopolitical and Financial Risks, Working Paper, James A. Baker III Institute for Public Policy, Rice University. http://www.rice.edu/nationalmedia/multimedia/militarization.pdf.

Jiang, Luming. (姜鲁鸣). 2001. "Certain Issues on Countering Future Economic Sanctions ( 关于我国未来反经济制裁的若干问题)." Military Economics Study (军事经济研究) 2001, no. 1 . 
Jiang, Zemin (江泽明). 2008. "Reflections on Energy Issues in China (对中国能源问题的思 考)." Journal of Shanghai Jiaotong University (Science) (上海交通大学学报自然科 学版) 2008, no. 13.

Jiashu, Wang. (王家枢). 2001. Oil and National Security (石油与国家安全). Beijing: China Geology Publish House (中国地质出版社), 2001.

Jin, Canrong. (金灿荣). July, 2010. "A Lecture by Chinese IR Scholars at Victoria University of Wellington." presented at the China's Ascent: New Superpower or New Global System?, Dunedin, University of Otago, New Zealand; Wellington, Victoria Unviersity of Wellington, New Zealand July, 2010.

JSB. 2010. The Statistical Handbook of Japan 2010 Edited by Japan Statistics Bureau \& Statistics Center. Tokyo: Japan Statistics Bureau, 2010.

Kater, J, E Steinfeld, S Ansolabehere, J Beer, and J Deuthch. 2007. The Futureof Coal. Massachusetts Institute of Technology. Cambridge, MA, 2007.

Kennedy, Paul. 1988. The Rise and Fall of the Great Powers. London: Fontana, 1988.

Klare, Michael T. 2001. "The New Geography of Conflict." Foreign Affairs 80, no. 3: 49-61.

Klare, Michael T. 2006. "Oil, Iraq, and American Foreign Policy: The Continuing Salience of the Carter Doctrine." International Journal 62, no. 1: 31-42.

Kong, Bo. 2005. An Anatomy of China's Energy Insecurity and Its Strategies. Pacific Northwest Center for Global Security. Seattle, WA, 2005.

Kraft, John, and Arthur Kraft. 1978. "On the Relationship between Energy and GNP." The Journal of Energy and Development 3, no. 2: 401-403.

Krause, Lawrence B., and Joseph S. Nye. 1975. "Reflections on the Economics and Politics of International Economic Organizations." In World Politics and International Economics, edited by C. Fred Bergsten and Lawrence B. Krause. Washington D.C.: The Brookings Institution.

Lague, David. 2008. "Blizzards and Coal Shortages Strain China's Rail Network " The New York Times.

Lan, Yao, Liu Bin, and Wu Zongxin. 2007. "Present and Future Power Generation in China " Nuclear Engineering and Design 237, no. 12-13: 1468-1473.

Lee, T. H. 1995. Politics of Energy Policy in Post-Mao China. Seoul: Asiatic Research Center, Korea University., 1995.

Leung, Guy C.K. 2010. "China's Oil Use, 1990-2008." Energy Policy 2, no. 38: 932-944.

Li, Yige. (李一戈). 2003. People's Daily Online (人民网). "The Suspense of the American War against Iraq: Will the 70,000 Barrels of Oil Be Shipped to China Safely? (美伊战 
争悬 念 : 70 万桶 原油能否安全抵达中国 )." http://www.people.com.cn/GB/jinji/31/179/20030219/926361.html.

Lieber, Robert J. 1980. "Energy, Economics and Security in Alliance Perspective." International Security 4, no. 4: 139-163.

Lieber, Robert J. 1992. "Oil and Power after the Gulf War." International Security 17, no. 1: 155-176.

Lim, Tai Wei. 2009. Oil in China: From Self-Reliance to Internationalization. Edited by Joseph Fewsmith and Yong-Nian Zheng, Series on Contemporary China, Vol. 18. : World Scientific Books, 2009.

Lin, Lun (林伦), and Erica S. Downs. 2006. "How China Interacts with US in Terms of Energy Security? (中美能源安全多棱镜——访布鲁金斯学会能源专家艾瑞克 - 道 斯博士)." China Petroleum Enterprise (中国石油企业) 2006, no. 05.

Lippmann, Walter. 1950. U.S. Foreign Policy: Shield of the Republic. Boston, Massachusetts: Little, Brown and Company, 1950.

Liu, Bo. (刘波). 2006. "China Enters Africa: The First Step to Build Largest Equity Oil Base (中国走进非洲: 最大海外份额油基地初成)." 21st Century Economy Report (21 世 纪经济报道).

Liu, Ming. (刘明). 2005. "The Variables in the Oil Issue (石油问题中的多个变量)." International Economic Review (国际经济评论) 2005, no. 6: 36-38.

Liu, Xinhua, and Yi Qin. (刘新华，秦仪). 2002. "China's Oil Security and Strategy Choices (中国的石油安全及其战略选择)." Contemporary International Relations (现代国际 关系) 2002 , no. 12 .

Lohr, Steve. 2005. "Unocal Bid Opens up New Issues of Security." The New York Times. Late Edition (East Coast), C.1.

Loungani, Prakash. 1986. "Oil Price Shocks and the Dispersion Hypothesis." Review of Economics and Statistics 68, no. 3: 536-539.

Luciani, Giacomo. 1988. "The Economic Content of Security." Journal of Public Policy 8, no. 2: 151-173.

Ma, Hengyun. 2009. "China's Energy Economy: Reforms, Market Development, Factor Substitution and the Determinants of Energy Intensity." PhD Thesis, University of Canterbury, 2009.

Ma, Xiaoqing, Rong Li, and K.L. Lo. 2010. "Power Industry Investment, Electricity Production and Economic Growth in China: Relationship and Forecast." In 45th International Universities Power Engineering Conference (UPEC), Aug 31, 2010 Sept 3, 2010. Cardiff, Wales: IEEE. 
Manera, Matteo, Cristina Cattaneo, and Elisa Scarp. 2008. "Industrial Coal Demand in China: A Provincial Analysis." FEEM Working Paper No. 8., Social Science Research Network. http://papers.ssrn.com/sol3/papers.cfm?abstract_id=1289203.

Mendl, Wolf. 1980. "The Security Debate in Japan." International Affairs 56, no. 4: 607-621.

Mork, Knut. 1989. "Oil and the Macroeconomy When Prices Go up and Down: An Extension of Hamilton's Results." Journal of Political Economy 97, no. 3: 740-744.

Nakićenović, Nebojša, Arnulf Grübler, and Alan McDonald. 1998. ed.^eds. Global Energy: Perspectives. Cambridge, UK: Cambridge University Press, 1998.

Narayan, Paresh Kumar, and Arti Prasad. 2008. "Electricity Consumption-Real GDP Causality Nexus: Evidence from Bootstrapped Causality Test for 30 Oecd Countries." Energy Policy 36, no. 2: 910-918.

NBS. (国家统计局). 2009c. "2-12 Share of the Contributions of the Three Strata of Industry to the Increase of the GDP (表 1-12 三次产业贡献率)." In China Statistical Year Book 2009 (中国统计年鉴 2009), edited by National Bureau of Statistics of China ( 中国国家统计局). Beijing: China Statistics Publishing House.

NBS. (国家统计局). 2009e. "4-28 Consumption of the Total Energy and Its Main Varieties by Sector (表 4-28 分行业能源消费总量) " In China Statistical Year Book 2009 (中 国统计年鉴 2009), edited by National Bureau of Statistics of China (中国国家统计 局). Beijing: China Statistics Publishing House.

NBS. (国家统计局). 2009a. "6-1 Total Production of Energy and Its Composition (表 6-1 能 源生产总量及构成)." In China Statistical Year Book 2009 (中国统计年鉴 2009), edited by National Bureau of Statistics of China. Beijing: China Statistics Publishing House.

NBS. (国家统计局). 2009b. "6-2 Total Consumption of Energy and Its Composition (表 6-2 能源消费总量及构成)." In China Statistical Year Book 2009 (中国统计年鉴2009), edited by National Bureau of Statistics of China. Beijing: China Statistics Publishing House.

NBS. (国家统计局). 2009d. "6-9 Consumption of Energy by Sector (2007) (表 6-9 按行业 分能源消费量, 2007 年)." In China Statistical Year Book 2009 (中国统计年鉴 2009), edited by National Bureau of Statistics of China (中国国家统计局). Beijing: China Statistics Publishing House.

NBS. (国家统计局). 2009. China Statistical Year Book 2009 (中国统计年鉴2009). Edited by National Bureau of Statistics of China (中国国家统计局编). Beijing: China Statistics Publishing House (中国统计出版社), 2009. 
NDRC. (国家发改委宏观经济研究院信息中心课题组). 2005. "The Influence of Economic Growth on Electricity Consumption (经济增长对电力需求的影响)." Review of Economic Research (经济研究参考) 2005, no. 78.

NDRC. (发改委). 2001. Tenth Five-Year Plan of Social and Economic Development Special Section on the Energy Development Programme (国民经济和社会发展第十 个五年计划一能源发展重点专项规划). China National Development and Reform Commission (中国国家发展和改革委员会). Beijing. www.ndrc.gov.cn.

Ning, Weijia. (宁维嘉). 2009. "China's Strategy in World's Current Energy Geopolitics Situation (能源地缘政治格局下的中国战略)." Master Thesis, Shanghai Academy of Social Sciences (上海社会科学院), 2009.

Northern Economy. 2005. "An Analysis of the Losses Caused by Power Shortage (全国电荒 造成惨重损失 三分天灾七分人祸)." Northern Economy (北方经济) 2005, no. 5.

Nye, J. S., and S. M Lynn-Jones. 1988. "International Security Studies: A Report of a Conference on the State of the Field." International Security 12, no. 4: 5-27.

OECD/IEA. 1983. Energy Balances of Oecd Countries, 1971-1981. Paris, 1983.

OECD/IEA. 2002. Energy Security. Internaiontal Energy Agency. Paris, 2002.

OECD/IEA. 2007. Energy Security and Climate Policy: Assessing Interactions. International Energy Agency. Paris, 2007.

OECD/IEA. 1985. Energy Technology Policy. International Energy Agency. Paris, 1985.

OECD/IEA. 1995. The IEA Natural Gas Security Study. International Energy Agency. Paris, 1995.

OECD/IEA. 2010a. "IEA Response System for Oil Supply Emergencies". International Energy Agency, Accessed in August, 2010, http://www.IEA.org/textbase/nppdf/free/response_system.pdf.

OECD/IEA. 2009. "IEA Statistics". 2009, /http://www.IEA.org/Textbase/stats/index.asp.

OECD/IEA. 2010. "Statistics by Country". International Energy Agency, Accessed in August, 2010, http://www.IEA.org/index.asp.

OECD/IEA. 2007a. World Energy Outlook 2007: China and India Insights. Edited by International Energy Agency, World Energy Outlook. Paris: International Energy Agency, 2007a.

Owen, A.D., and Penelope N. Neal. 1989. "China's Potential as an Energy Exporter." Energy Policy 1989, no. 17: 485-500. 
Ozturk, Ilhan. 2010. "A Literature Survey on Energy-Growth Nexus." Energy Policy 38, no. 1: 340-349.

Painter, David S. 1991. "International Oil and National Security." Daedalus, Searching for Security in a Global Economy 120, no. 4: 183-206.

Palti, Leslie S. 2007. "Energy Relations Amongst the United States, the European Union and the People's Republic of China: A Strategic Triangle or Three Sides without a Triangle?". MA Thesis, Tufts University, 2007.

Peng, Wuyuan. 2010. "Coal Sector Reform and Its Implications for the Power Sector in China." Resource Policy Article in Press 2010 (doi:10.1016/j.resourpol.2010.06.001).

People's Daily. Sep 27, 2009. People's Daily Online (in English). "China Becomes World's Largest Energy Producer." http://english.peopledaily.com.cn/90001/90778/90857/90860/6769170.html.

People's Daily. July 19 2005. People's Daily Online (人民网). "Chongqing Fights for the Passage of the China-Burma Oil Pipeline (重庆力争中缅石油管道入渝)." http://finance.people.com.cn/GB/1038/3277783.html.

People's Daily. Dec 15, 2005. People's Daily Online (人民网). "The First Phase of SinoKazakhstan Oil Pipeline Has Been Competed and Is Put into Use (中哈输油管道一 期工程竣工投产)." http://politics.people.com.cn/GB/1026/3946513.html.

People's Daily. Sep 24, 2001. People's Daily Online (in English). "U.S. 'Attacks September 11' Focusing on China's Oil Security." http://english.people.com.cn/english/200109/21/eng20010921_80742.html.

People's Daily. Sep 27, 2009 People's Daily Online (in English). "China Becomes World's Largest Energy http://english.peopledaily.com.cn/90001/90778/90857/90860/6769170.html.

People's Daily. June 13, 2004. People's Daily Online (in English). "Severe Energy Shortage Warned." http://english.peopledaily.com.cn/200406/13/eng20040613_146171.html.

People’ s Daily. Oct 8, 2006. People's Daily Online (人民网). "With Four Bases, Our Spr Will Be Put into Use in October (建四大储备基地 我国战略石油储备 10 月启动)." http://finance.people.com.cn/GB/4685561.html.

Pinder, John. 1984. "European Economic Security: How Can We Master the Modern Economy?" International Journal 40, no. 1: 128-144.

Qi, Zhixin, Wenying Chen, and Zongxin Wu. (齐志新, 陈文颖, 吴宗金金). 2007. "Heavy Industry Share Increase Is Causing Higher Energy Consumption." China Economist ( 中国经济学人，英文版) 2007, no. 4: 37-46. 
Qin, Xuanren. (秦宣仁). 2004. "The International Environment and the Diplomatic Energy Strategies of the Major Powers (国际大环境及大国能源外交运筹)." International Petroleum Economics (国际石油经济) 12, no. 1.

Rasche, Robert H., and John A. Tatom. 1981. "Energy Price Shocks, Aggregate Supply and Monetary Policy: The Theory and the International Evidence." In Carnegie-Rochester Conference Series on Public Policy, 14.

Ray, Dennis M. 1975. "China's Perception of Social Imperialism and Economic Dependency: The Impact of Soviet Aid." Stanford Journal of International Studies 1975, no. 5: 3682.

Ren, Na, and Nuan Sun. (任娜, 孙暖). 2007. "A Geopolitical Perspective of Energy Security - the Case of U.S. Global Energy Secuirty Strategy (地缘政治视角下的能源安全 一以美国全球能源安全战略为例)." Forum of World Economics \& Politics (世界经 济与政治论坛) 2007, no. 2: 84-89.

Reynolds, C. 1973. Theory and Explanation in International Politics. London: Martin Robertson, 1973.

RFE. 2009. "Europe's Dangerous Dependence on Russian Gas ". Radio Free Europe Website, March 26, 2009, http://www.rferl.org/content/Europes_Dangerous_Dependence_on_Russian_Gas/156 2635.html.

Rogers, Simon. 2010. Guardian Datablog. 25 March 2010 "How China Overtook the Us in Renewable Energy." http://www.guardian.co.uk/news/datablog/2010/mar/25/chinarenewable-energy-pew-research.

Rose, Euclid A. 2004. "OPEC's Dominance of the Global Oil Market: The Rise of the World's Dependency on Oil." Middle East Journal 58, no. 3: 424-434.

Rothschild, E. 1995. "What Is Security." Daedalus 124, no. 3: 53-98.

Rourke, John T. 1993. International Politics on a World Stage. Hartford, Connecticut: The Dushkin Publishing Group, 1993.

Santini, Danilo. 1985. "The Energy-Squeeze Model: Energy Price Dynamics in U.S. Business Cycles." International Journal of Energy Systems 5, no. 1: 159-194.

Schäfer, Andreas. 2005. "Structural Change in Energy Use " Energy Policy 33, no. 4: 429437.

Shiu, Alice, and Pun-Lee Lam. 2004. "Electricity Consumption and Economic Growth in China." Energy Policy 32, no. 1: 47-54

Shu, Xianlin, and Gaocheng Yan. (舒先林; 阎高程). 2004. "Petroleum: The Core of Chinese Energy Sources Security and the International Strategy (石油: 中国能源的核心与国 际战略)." Techno-economics In Petrochemicals (石油化工技术经济) 2004, no. 3. 
Smil, Vaclav. 2000. "Energy in the Twentieth Century: Resources, Conversions, Costs, Uses, and Consequences." Annual Review of Energy and the Environment 2000, no. 25: 2151.

Song, Xiaofeng. (宋效峰). 2008. "Oil Security一in Views of Tradtional and Untradtional Security Concept (传统安全与非传统安全双重视角下的石油安全)." Jounrnal of Scientific Decision-Making (科学决策) 2008, no. 2.

Stares, Paul B. 2000. "Introduction and Overview." In Rethinking Energy Security in East Asia, edited by Paul B. Stares. Tokyo: Japan Center for International Exchange.

Stern, Roger. 2006. "National Security and Politcal Economic Dimensions of Oil Market Power." PhD Dissertation, Johns Hopkins University, 2006.

Stobaugh, Robert, and Daniel Yergin. 1980. Energy Future: Report of the Energy Project at Harvard Business School. New York: Ballantine Books, 1980.

Sun, Fei, Ming Xu, and Wenkai Zhao. (孙飞, 徐明, 赵文锴). 2010. "China's Economic Trend (《中国经济大趋势》选载) ". China Economy Web (中国经济网), April 30 ,

http://book.ce.cn/read/economy/zgjjdqs/201004/30/t20100430 21347968 18.shtml.

Sun, Yaping 2010. CRI Online (国际在线网站). (孙亚萍). "Putin Himself Starts the SinoRussia Oil Pipeline, Decalring the Sino-Russian Energy Cooperation Will Be Deepen (普京亲自开启中俄石油管道 称 两国能源合 作深化)." http://gb.cri.cn/27824/2010/08/30/110s2973381.htm.

Tang, James. 2006. With the Grain or against the Grain? Energy Security and Chinese Foreign Policy in the Hu Jintao Era. Centre for Northeast Asian Policy Studies, The Brookings Institution. 2006.

Tatom, John A. 1988. "Are the Macroeconomic Effects of Oil-Price Changes Symmetric? A Comment." In Carnegie-Rochester Conference Series on Public Policy 28, 369-378: Elsevier.

Tatsu, Kambara , and Howe Christopher. 2007. China and the Global Energy Crises: Development and Prospects for China's Oil and Natural Gas: Edward Elgar Publishing, 2007.

Tian, Chunrong. (田春荣). 2002. "An Analysis of China's Oil Imports and Exports in 2001 (2001 年中国石油进出口状况分析)." International Petroleum Economics (国际石 油经济) 10, no. 3 .

Torrens, Ian M. 1982. "Oil Supply and Demand in Western Europe, the Oil Industry, and the Role of IEA." In After the Second Oil Crisis: Energy Policies in Europe, America, and Japan, edited by Wilfrid L. Kohl, 23-37. Lexington, Massachusetts; Toronto: Lexington Books. 
Ullman, Richard H. 1983. "Redefining Security." International Security 8, no. 1: 129-153.

UN. 1982. The Relationship between Disarmament and Development. United Nations Centre for Disarmament. New York, 1982.

Walt, Stephen M. 1991. "The Renaissance of Security Studies." International Studies Quarterly 35, no. 2: 211-239.

Wang, Bing. 2007c. "An Imbalanced Development of Coal and Electricity Industries in China." Energy Policy 35, no. 10: 4959-4968.

Wang, Chunyan. (王春燕). 2003. "War, Oil Price and Our Oil Security (战争 - 油价与我国 的石油安全)." China Petroleum and Chemical Industries (中国石油和化工) 2003, no. 4: 19-22.

Wang, Hai. (汪海). 2007. "From the Beibu Gulf to the Indochina Peninsula and the Indian Ocean: Building a China-Asean Strategic Passage Which Serves to Avert a Malacca Dilemma (从北部湾到中南半岛和印度洋一构建中国联系东盟和避开 “马六甲困 局” 的战略通道)." World Economics and Politics (世界经济与政治) 2007, no. 9: 47-54.

Wang, Hui, and Wenjuan Du. 2009. China Daily Online (English Edition). 6 January 2009. "Chinese Naval Fleet Sails into Gulf of Aden." http://www.chinadaily.com.cn/china/2009-01/06/content_7371034.htm.

Wang, Lijiu. (王邸久). 2006. "The Russian Oriental Energy Diplomacy and Sino-Russia Energy Cooperation (俄罗斯东方能源外交与中俄能源合作)." Contemporary International Relations (现代国际关系) 2006, no. 8: 8-20.

Wang, Meng. (王猛). June 7, 2004. "China's Electric Power Shortage Is Aggravating, Zhejiang Province Plans to Cope with the 'Electricity Crisis' (中国电力短缺持续加重 浙江应对 “电荒”做打算)". China International Online (中国国际在线), http://gb.cri.cn/3821/2004/06/07/106@187129.htm.

Wang, Qiang, Huan-Ning Qiu, and Yaoqiu Kuang. 2009a. "Market-Driven Energy Pricing Necessary to Ensure China's Power Supply." Energy Policy 37, no. 7: 2498-2504

Wang, Xiuli. (汪秀丽). 2004. "An Analysis of the 2004 Electric Power Shortage (透视 2004 年电荒)." Water Resources and Electric Power (水利电力科技) 30, no. 4: 1-15.

Wasser, R. M. 2007. "Clean Ambitions." China Dialogue. , http://www.chinadialogue.net/article/show/single/en/1458-Clean-ambitions

WDI. 2010. "World Development Indicators: Energy Net Imports as Percentage of Energy Use " The World Bank, http://data.worldbank.org/indicator.

Wionczek, Miguel S. 1983. "Energy and International Security in the 1980s: Realities or Misperceptions?" Third World Quarterly 5, no. 4: 839-847. 
WNA. 2010a. "Nuclear Power in China". World Nuclear Association, Accessed in August, 2010, http://www.world-nuclear.org/info/inf63.html.

WNA. 2010. "Nuclear Power in the USA". World Nuclear Association, Accessed in August, 2010, http://www.world-nuclear.org/info/inf41.html.

Wolfers, Arnold. 1952. ""National Security" As an Ambiguous Symbol." Political Science Quarterly 67, no. 4: 481-502.

Wolfowitz, P. 1992. Defense Planning Guidance U.S. Department of Defense. Washington, DC.

Wu, Friedrich W. Y. 1981. "From Self-Reliance to Interdependence?: Developmental Strategy and Foreign Economic Policy in Post-Mao China." Modern China 7, no. 4: 445-482.

Wu, Lei. (吴否). 2003. "The Impact of the Iraq War on Our Oil Security (伊拉克战争对我国 石油安全的影响)." International Forum (国际论坛) 5, no. 4.

Wu, Lei, and Xuejun Liu. (吴否, 刘学军). 2009. "Energy Security and Sino-US Relations: An Analysis from Political Economic Perspectives (能源安全与中美关系的政治经 济学分析)." Fudan American Review (美国问题研究) 2009, no. 1.

Wu, Qiang. (吴强). 2001. "Energy Diplomacy: The New Task Facing China's Diplomacy in the 21st Century (能源外交: 21 世纪中国的外交新课题)." Studies of International Politics (国际政治研究) 2001, no. 1: 12-16.

Xia, Yishan. (夏义善). 2003. "China's Energy Security and Some Perspectives of Solution ( 中国能源安全问题及解决前景)." Peace and Development (和平与发展) 2003, no. 4: $20-24$.

Xing, Liu. (刘星). 2005. "The Impact of the Continued Increase in Oil Prices on China's Economy and Related Trades (原油价格持续上涨对我国经济和相关行业的影响)." Group Economy Studies(集团经济研究) 2005, no. 11: 18-19.

Xinhua. Oct 17, 2008. Xinhua News (新华网). "China's High Way: 30 Years after the 'Reform and Open' (中国高速公路改革开放 30 年迅猛发展)." http://news.xinhuanet.com/newscenter/2008-10/17/content_10211010.htm.

Xinhua. July 28, 2006. Xinhua News (新华网). "China's Spr Will Mainly Rely on 'Equity Oil' (中国油储将以“份额油”为主“两条腿走路”).” http://news.xinhuanet.com/fortune/2006-07/28/content 4887064.htm.

Xinhua. August 3, 2005. "Cnooc Withdraws Unocal Bid ". Xinhua News Agency, http://www.china.org.cn/english/2005/Aug/137165.htm. 
Xinhua. 2010. Xinhua News (新华网). January 14, 2010. "How to Comprehend the Current Rising Coal Price and Supply Disruptions in Some Regions (如何看待当前煤价上涨 和 局 部 供 应 紧 张 )." http://news.xinhuanet.com/fortune/201001/14/content 12810089.htm.

Xinhua. July 22, 2010. "Why IEA Names China World's Top Energy User ". Xinhua News (English Version), http://news.xinhuanet.com/english2010/indepth/201007/22/c 13409345.htm.

Xu, Yugao, and Yufeng Yang. (徐玉高, 杨玉峰). 2004. "The Strategy Framework for China's Oil Security (中国石油安全战略构想)." Energy of China (中国能源) 2004, no. 08.

Yang, Ming. 2008. "China's Energy Efficiency Target 2010." Energy Policy 36, no. 2: 561570.

Yang, Ming. 2008. "China's Energy Efficiency Target 2010." Energy Policy 36, no. 2: 561570.

Yang, Yilin. (杨伊玲). 2005. "Five Years of Electricity Shortage Caused 1 Trillion Loss (10000 亿五年电荒损失当头棒喝)." C-Thinking (新远见) 2005, no. 2.

Ye, Qumao, and Hongjun Jiang. 2006. "A Political Economy Analysis of the CNOOCUnocal Bid (中海油并购优尼科的政治经济学分析) " Theory Monthly (理论月刊) 2006, no. 8: 127-130.

Yergin, Daniel. 1988. "Energy Security in the 1990s." Foreign Affairs 67, no. 1: 110-132.

Yergin, Daniel. 2006. "Ensuring Energy Security." Foreign Affairs 85, no. 2: 69.

Yergin, Daniel. 2008. The Prize: The Epic Quest for Oil, Money, and Power New York: Simon and Shuster, 2008.

Yorke, Valerie. 1981. "Oil, the Middle East and Japan's Search for Security." International Affairs 57, no. 3: 428-448.

Yu, Eden S.H., and Jai-Young Choi. 1985. "The Causal Relationship between Energy and Gnp: An International Comparison." Journal of Energy and Development 10, no. 2: 249-272.

Yu, Peng. (于鹏). 2006. "The Measures to Guarantee National Oil Security in a Time of High Oil Price (高油价时代保障国家石油安全之策)." Macroeconomic Management (宏 观经济管理), no. 11 .

Yuan, Jiahai, Changhong Zhao, Shunkun Yu, and Zhaoguang Hu. 2007. "Electricity Consumption and Economic Growth in China: Cointegration and Co-Feature Analysis." Energy Economics 29, no. 6: 1179-1191. 
Zha, Daojiong. (查道炣). 2005. "China's Energy Security一from an International Relations Perspective(从国际关系角度看中国能源安全)." International Economic Review(国) 际经济评论) 2005, no. 6 .

Zha, Daojiong. 2010. "Oiling the Wheels of Foreign Policy? Energy Security and China's International Relations." Working Paper No.1, Asia Security Initiative Policy Series, RSIS Centre for Non-Tradtional Security (NTS) Studies, Nanyang Technological University.

Zhang, Hongmin, Jiali Ge, Jihao Hu, and Xiaozhe Guo. (张宏民, 葛家理, 胡机豪, 郭小 哲). 2002. "The Financial Dimension of Oil and Our Means to Achieve Oil-Economic Security (石油金融化及我国石油经济安全的对策研究)." Jounrnal of the University of Petroleum (石油大学学报社会科学版) 18, no. 4: 1-3.

Zhang, Jie. (张洁). 2005. "The Malacca Factor of China's Energy Security (中国能源安全中 的马六甲因素)." Studies of International Politics (国际政治研究) 2005, no. 3: 1827.

Zhang, Ping. (张平). April 22, 2008. The State Council's Report on the Blizzards Harzard and the Countermeasures (国务院关于抗击低温雨雪冰冻灾害及灾后重建工作情 况的报告). The State Council of People's Republic of China (国务院). People's Daily Online (人民网). Beijing. http://npc.people.com.cn/GB/7152460.html.

Zhang, Shuguang. 2005a. People's Daily Online (人民网). (张曙光). "The Rising Oil Price and Energy Security ( 油 价上 涨与 能 源 安 全 )." http://www.people.com.cn/GB/paper2515/14657/1302332.html.

Zhang, Shuwei, Kejun Jiang, and Deshun Liu. 2007. "Passenger Transport Modal Split Based on Budgets and Implication for Energy Consumption: Approach and Application in China." Energy Policy 35, no. 9: 4434-4443.

Zhang, Shuwei, and Deshun Liu. (张树伟, 刘德顺). 2006. "Analysis of the Relationship between Power Shortage and Economic Growth (电力严重短缺与经济发展关系分 析)." Power Demand Side Management (电力需求管理) 8, no. 1: 11-13.

Zhang, Wenmu. (张文木). 2003. "China's Energy Security and Policy Choices (中国能源安 全与政策选择)." World Economics and Politics (世界经济与政治) 2003, no. 5.

Zhang, Wenmu. (张文木). 2003. "Economic Globalization and China’ s Seapower (经济全 球化与中国海权)." Strategy and Management (战略与管理) 2003, no. 1.

Zhang, Wenmu. (张文木). 1998. "US Petroleum Geopolitics and the Security of China's Tibet and Xinjiang Regions (美国的石油地缘战略与中国西藏新疆地区安全)." Strategy and Management (战略与管理) 1998, no. 2. 
Zhang, Youwen, and Renwei Huang. (张幼文, 黄仁伟等). 2006. China International Status Report 2006 (2006 中国国际地位报告). Beijing: Renmin (人民出版社), 2006.

Zhang, Yuyan, and Qingyou Guan. (张宇燕, 管清友). 2007. "The World Energy Siutation and China's Energy Security (世界能源格局与中国的能源安全)." World Economics (世界经济) 2007, no. 9: 17-30.

Zhao, Hongtu. (赵宏图). 2007. "A Perspective on Energy Diplomacy - with Reflections on Energy Diplomacy in China (透视能源外交一一兼谈对中国能源外交的思考)." International Petroleum Economics (国际石油经济) 2007, no. 10: 41-47.

Zhao, Hongtu. (赵宏图). 2007. "Rethinking on Malacca Dilemma and China's Energy Security ( “马六甲困局”与中国能源安全再思考)." Contemporary International Relations (现代国际关系) 2007, no. 6: 36-42.

Zhao, Hongtu, and Rong Li. (赵宏图, 李荣). 1999. "The Necessity of Establishing Our Strategic Oil Reserve (建立我国战略石油储备势在必行)." International Petroleum Economics (国际石油经济) 7, no. 2: 24-56.

Zhao, Xiaoli, Chunbo Ma, and Dongyue Hong. 2010. "Why Did China's Energy Intensity Increase During 1998-2006: Decomposition and Policy Analysis " Energy Policy 38, no. 3: 1379-1388.

Zhou, Yunheng, and Zhongbo Zhu. (周云亨, 朱中博). 2009. "Reflection on China's Petroleum Security (中国石油安全再思考——析油价回落时的石油安全问题)." Journal of Jiangnan Social University (江南社会学院学报) 2009, no. 2: 9-13.

Zhou, Zenan. (周则男). 2004. "The Hiking Oil Price and Energy Security (油价䢠升能源安 全须正视)." China Petroleum and Chemical Industries (中国石油和化工) 2004, no. 12: 31-33.

Zhu, Chengzhang. (朱成章). 2000. "'Power First' Is the Objective Law of Economic Development (电力先行是经济发展的客观规律)." Electric Power Technologic Economics (电力技术经济) 2000, no. 3 .

Zhu, Zhongyuan. (朱中原). 2006. "Power Shortage - Another Kind of SARS? (电荒=另类 “Sars” ?)." China Report (中国报道) 2006, no. 4: 29-38.

Zuo, Taihang, and Junmei Yao. (左太行, 姚俊梅). 2001. "The Impacts of 'the Third Oil Crisis' and the Countermeasures - the Impacts of High Oil Price on Our Economy ( “第三次石油危机” 的冲击和应对一一高油价对我国经济的影响及对策)." China Petroleum (中国石油) 2001, no. 1: 13-14 